Prepared in cooperation with the U.S. Army Corps of Engineers

\title{
Passage and Survival Probabilities of Juvenile Chinook Salmon at Cougar Dam, Oregon, 2012
}

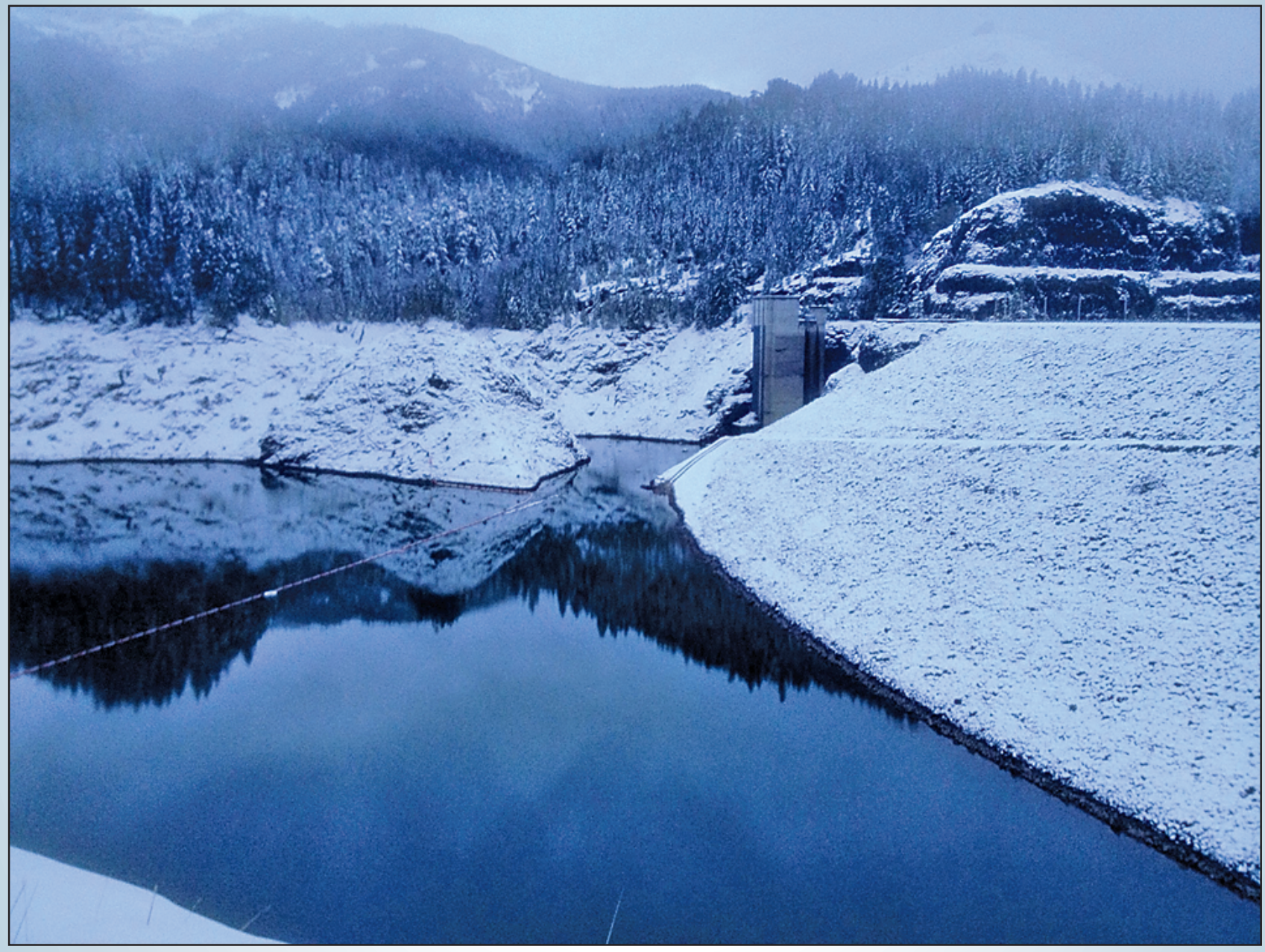

Open-File Report 2014-1038 
Cover: Photograph showing the forebay and temperature control tower at Cougar Dam, Oregon, December 2012. (Photograph by John Beeman, U.S. Geological Survey.) 


\section{Passage and Survival Probabilities of Juvenile Chinook Salmon at Cougar Dam, Oregon, 2012}

By John W. Beeman, Scott D. Evans, Philip V. Haner, Hal C. Hansel, Amy C. Hansen, Collin D. Smith, and Jamie M. Sprando

Prepared in cooperation with the U.S. Army Corps of Engineers

Open-File Report 2014-1038

U.S. Department of the Interior

U.S. Geological Survey 


\section{U.S. Department of the Interior \\ SALLY JEWELL, Secretary}

\section{U.S. Geological Survey \\ Suzette M. Kimball, Acting Director}

U.S. Geological Survey, Reston, Virginia: 2014

For more information on the USGS-the Federal source for science about the Earth,

its natural and living resources, natural hazards, and the environment-visit

http://www.usgs.gov or call 1-888-ASK-USGS

For an overview of USGS information products, including maps, imagery, and publications, visit $h$ ttp://www.usgs.gov/pubprod

To order this and other USGS information products, visit http://store.usgs.gov

Suggested citation:

Beeman, J.W., Evans, S.D., Haner, P.V., Hansel, H.C., Hansen, A.C., Smith, C.D., and Sprando, J.M., 2014, Passage and survival probabilities of juvenile Chinook salmon at Cougar Dam, Oregon, 2012:: U.S. Geological Survey OpenFile Report 2014-1038, 64 p., http://dx.doi.org/10.3133/ofr20141038/.

ISSN 2331-1258 (online)

Any use of trade, firm, or product names is for descriptive purposes only and does not imply endorsement by the U.S. Government.

Although this information product, for the most part, is in the public domain, it also may contain copyrighted materials as noted in the text. Permission to reproduce copyrighted items must be secured from the copyright owner. 


\section{Contents}

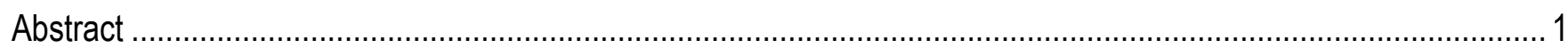

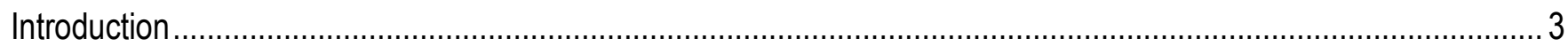

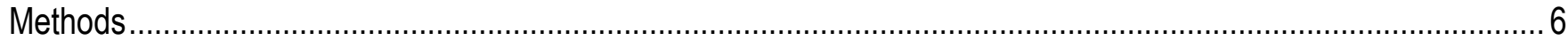

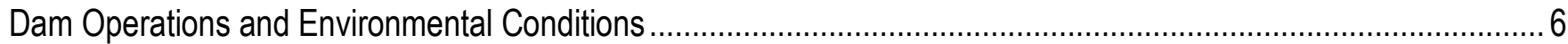

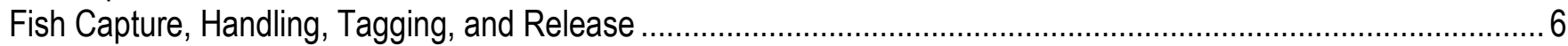

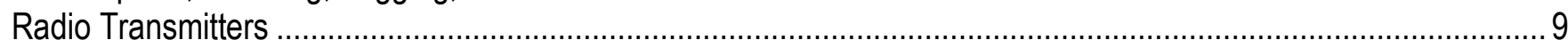

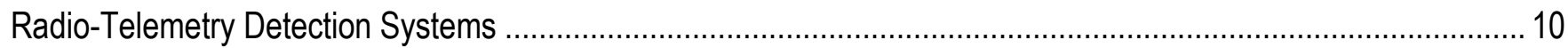

Passive Integrated Transponder-Tag Detection System at Leaburg Dam ....................................................... 11

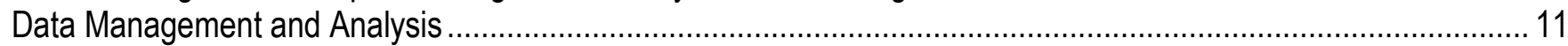

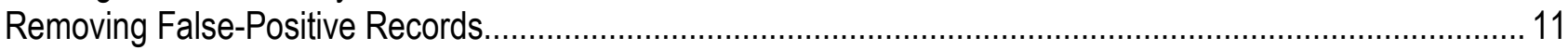

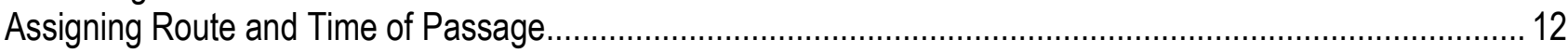

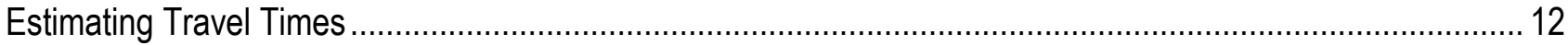

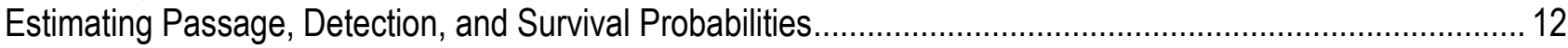

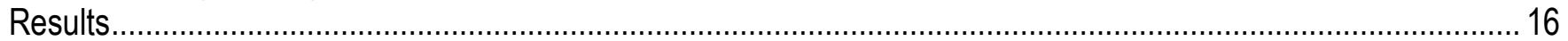

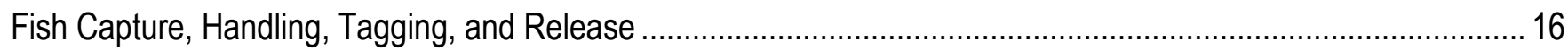

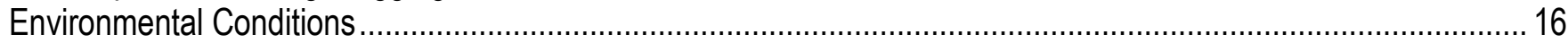

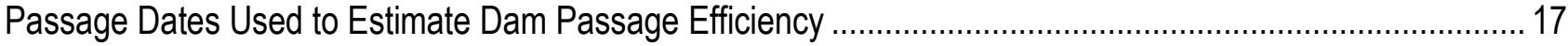

Passage Dates Used to Estimate Dam Passage and Survival Probabilities ................................................ 18

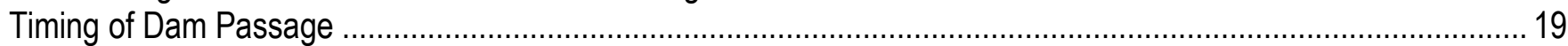

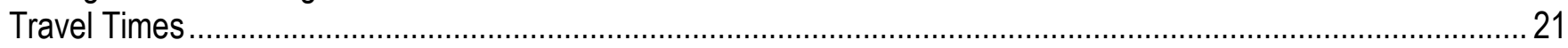

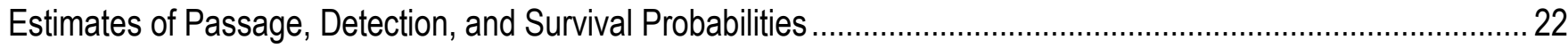

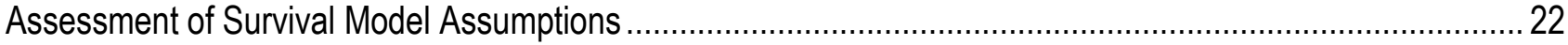

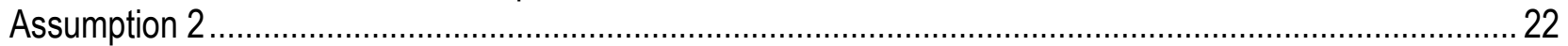

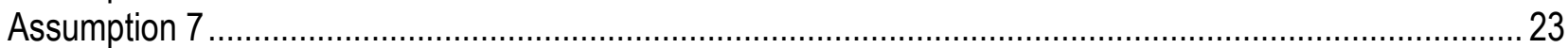

Assumption 9

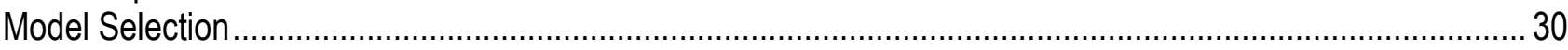

Route-Specific Passage Probabilities ................................................................................................. 31

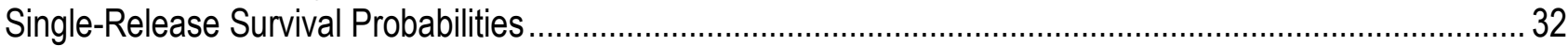

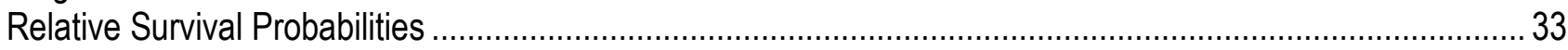

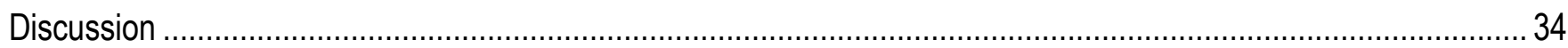

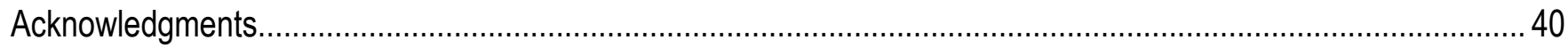

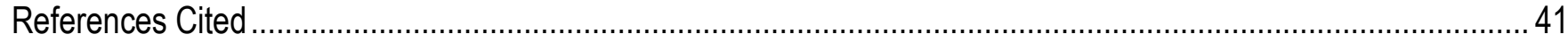

Appendix A. Type and Location of Radio-Telemetry Detection Sites............................................................... 44

Appendix B. Summaries of the Allocation of Tagger Effort and the Numbers and Sizes of Fish Released

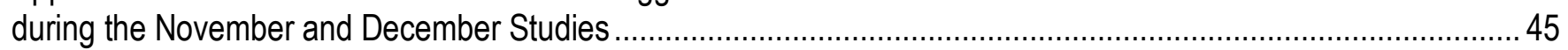

Appendix C. Comparisons of Fish from the Two Rearing Groups .................................................................. 50

Appendix D. Summaries of the Environmental and Operating Conditions at Cougar Dam, Oregon,

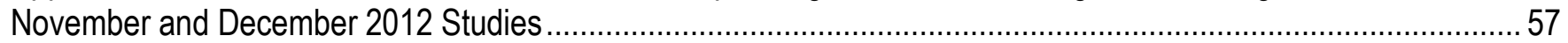

Appendix E. Estimating the Adequacy of Transmitter Life ......................................................................... 59

Appendix F. Comparisons of Models Considered for Estimating Detection, Passage, and Survival

Probabilities of Juvenile Chinook Salmon Released Near Cougar Dam, Oregon, November and December 2012.62

Appendix G. Single-Release Estimates of Reach-Specific Survival of Treatment and Control Groups

Used to Estimate Relative Survival of Fish Passing Cougar Dam, Oregon, November and December 2012 ...........64 


\section{Figures}

Figure 1. Cross-section of the temperature control tower at Cougar Dam, Oregon, showing the regulating outlet $(\mathrm{RO})$ passage route

Figure 2. Schematic of release locations and radio-telemetry-antenna sites (circles) near Cougar Dam, Oregon, during the November and December 2012 studies.

Figure 3. Photographs of fish release systems for the treatment (left) and control (right) groups at Cougar Dam, Oregon

Figure 4. Schematic of study area showing radio-telemetry detection sites downstream of Cougar Dam, Oregon, used during the November and December 2012 studies

Figure 5. Schematic of the Route Specific Survival Model structure used to estimate detection, passage, and survival probabilities

Figure 6. Graphs showing environmental conditions at Cougar Dam, Oregon, during the November and December 2012 studies

Figure 7. Graph showing hour of known dam passage of radio-tagged juvenile Chinook salmon released in Cougar Reservoir, Oregon, November and December 2012

Figure 8. Graphs showing dam passage timing of radio-tagged juvenile Chinook salmon released into Cougar Reservoir, Oregon, during the November and December 2012 study periods.

Figure 9. Graphs showing travel time distributions of the three release groups from release to first detection at the Hops Farm site.

Figure 10. Graphs showing travel time distributions of control and treatment groups of radio-tagged juvenile Chinook salmon released near Cougar Dam, Oregon, November 6-10, 2012

Figure 11. Graphs showing site-specific daily passage percentages of radio-tagged juvenile Chinook salmon released near Cougar Dam, Oregon, November 6-10, 2012

Figure 12. Graphs showing travel time distributions of control and treatment groups of radio-tagged juvenile Chinook salmon released near Cougar Dam, Oregon, December 18-22, 2012

Figure 13. Graphs showing site-specific daily passage percentages of radio-tagged juvenile Chinook salmon released near Cougar Dam, Oregon, December 18-22, 2012

Figure 14. Graphs showing estimates and 95-percent confidence intervals of unadjusted reach-specific relative survival of radio-tagged juvenile Chinook salmon released near Cougar Dam, Oregon, November and December 2012

Figure 15. Graph showing regulating outlet (RO) fish passage efficiency curve for juvenile Chinook salmon at Cougar Dam, Oregon, based on the available data. 


\section{Tables}

Table 1. Summary of radio-telemetry detection sites

Table 2. Summary of dam passage percentages of radio-tagged juvenile Chinook salmon released into the reservoir and into the temperature control tower at Cougar Dam, Oregon, November and December 2012.

Table 3. Comparisons of models with and without effects of tagger on estimates of survival of radio-tagged juvenile Chinook salmon released near Cougar Dam, Oregon, November and December 2012.

Table 4. Results of Wilcoxon tests comparing distributions of travel times (days) of treatment and control groups of fish released near Cougar Dam, Oregon, November 6-10, 2012

Table 5. Results of Wilcoxon tests comparing distributions of travel times (days) of treatment and control groups of fish released near Cougar Dam, Oregon, December 18-22, 2012

Table 6. Estimates of route-specific passage probabilities of radio-tagged juvenile Chinook salmon released at Cougar Dam, Oregon, November and December 2012.

Table 7. Estimates of relative reach-specific survival probabilities of radio-tagged juvenile Chinook salmon passing through the regulating outlet at Cougar Dam, Oregon, November and December 2012 34

Table 8. Summary of test conditions of studies of passage survival through the regulating outlet at Cougar Dam, Oregon 


\section{Conversion Factors and Datum}

\section{Conversion Factors}

Inch/Pound to SI

\begin{tabular}{lll}
\hline \multicolumn{1}{c}{ Multiply } & \multicolumn{1}{c}{ By } & \multicolumn{1}{c}{ To obtain } \\
\hline foot $(\mathrm{ft})$ & 0.3048 & meter $(\mathrm{m})$ \\
cubic foot $\left(\mathrm{ft}^{3}\right)$ & 0.02832 & cubic meter $\left(\mathrm{m}^{3}\right)$ \\
cubic foot per second $\left(\mathrm{ft}^{3} / \mathrm{s}\right)$ & 0.02832 & cubic meter per second $\left(\mathrm{m}^{3} / \mathrm{s}\right)$ \\
\hline
\end{tabular}

SI to Inch/Pound

\begin{tabular}{lll}
\hline \multicolumn{1}{c}{ Multiply } & \multicolumn{1}{c}{ By } & \multicolumn{1}{c}{ To obtain } \\
\hline millimeter $(\mathrm{mm})$ & 0.03937 & inch (in.) \\
kilometer $(\mathrm{km})$ & 0.6214 & mile (mi) \\
kilometer $(\mathrm{km})$ & 0.5400 & mile, nautical (nmi) \\
liter $(\mathrm{L})$ & 0.2642 & gallon (gal) \\
gram $(\mathrm{g})$ & 0.03527 & ounce, avoirdupois (oz) \\
\hline
\end{tabular}

Temperature in degrees Celsius $\left({ }^{\circ} \mathrm{C}\right)$ may be converted to degrees Fahrenheit $\left({ }^{\circ} \mathrm{F}\right)$ as follows:

${ }^{\circ} \mathrm{F}=\left(1.8 \mathrm{x}^{\circ} \mathrm{C}\right)+32$.

\section{Datum}

Vertical coordinate information is referenced to the National Geodetic Vertical Datum of 1929 (NGVD29).

Elevation, as used in this report, refers to distance above the vertical datum. 


\title{
Passage and Survival Probabilities of Juvenile Chinook Salmon at Cougar Dam, Oregon, 2012
}

\author{
By John W. Beeman, Scott D. Evans, Philip V. Haner, Hal C. Hansel, Amy C. Hansen, Collin D. Smith, and Jamie \\ M. Sprando
}

\begin{abstract}
This report describes studies of juvenile-salmon dam passage and apparent survival at Cougar Dam, Oregon, during two operating conditions in 2012. Cougar Dam is a 158-meter tall rock-fill dam used primarily for flood control, and passes water through a temperature control tower to either a powerhouse penstock or to a regulating outlet (RO). The temperature control tower has moveable weir gates to enable water of different elevations and temperatures to be drawn through the dam to control water temperatures downstream. A series of studies of downstream dam passage of juvenile salmonids were begun after the National Oceanic and Atmospheric Administration determined that Cougar Dam was impacting the viability of anadromous fish stocks. The primary objectives of the studies described in this report were to estimate the route-specific fish passage probabilities at the dam and to estimate the survival probabilities of fish passing through the RO. The first set of dam operating conditions, studied in November, consisted of (1) a mean reservoir elevation of 1,589 feet, (2) water entering the temperature control tower through the weir gates, (3) most water routed through the turbines during the day and through the RO during the night, and (4) mean RO gate openings of 1.2 feet during the day and 3.2 feet during the night. The second set of dam operating conditions, studied in December, consisted of (1) a mean reservoir elevation of $1,507 \mathrm{ft}$, (2) water entering the temperature control tower through the RO bypass, (3) all water passing through the RO, and (4) mean RO gate openings of 7.3 feet during the day and 7.5 feet during the night. The studies were based on juvenile Chinook salmon (Oncorhynchus tshawytscha) surgically implanted with radio transmitters and passive integrated transponder (PIT) tags. Inferences about general dam passage percentage and timing of volitional migrants were based on surface-acclimated fish released in the reservoir. Dam passage and apparent survival probabilities were estimated using the Route-Specific-Survival Model with data from surface-acclimated fish released near the water surface directly upstream of the temperature control tower (treatment group) and slightly downstream of the dam (control group). In this study, apparent survival is the joint probability of surviving and migrating through the study area during the life of the transmitters.

Two rearing groups were used to enable sufficient sample sizes for the studies. The groups differed in feed type, and for the December study only, the rearing location. Fish from each group were divided nearly equally among all combinations of release sites, release times, and surgeons. The sizes, travel times, and survivals of the two rearing groups were similar. There were statistical differences in fish lengths and travel times of the two groups, but they were small and likely were not biologically meaningful. There also was evidence of a difference in single-release estimates of survival between the rearing groups during the December study, but the differences had little effect on the relative survival estimates so the analyses of passage and survival were based on data from the rearing groups pooled.
\end{abstract}


Conditions during the December study were more conducive to passing volitionally migrating fish than conditions during the November study. The passage percentage of the fish released in the reservoir was similar between studies (about 70 percent), but the passage occurred in a median of 1.0 day during the December study and a median of 9.3 days during the November study. More than 93 percent of the dam passage of volitionally migrating fish occurred at night during each study. This finding corroborates results of previous studies at Cougar Dam and suggests that the operating conditions at night are most important to volitionally migrating fish, given the current configuration of the dam.

Most fish released near the temperature control tower passed through the RO. A total of 92.2 percent of the treatment group passed through the RO during the November study and the RO was the only route open during the December study.

The assumptions of the survival model were either met or adjusted for during each study. There was little evidence that tagger skill or premature failure of radio transmitters had an effect on survival estimates. There were statistically significant differences in travel times between treatment and control groups through several of the river reaches they had in common, but the differences were typically only a few hours, and the two groups likely experienced the same in-river conditions. There was direct evidence of bias due to detection of euthanized fish with live transmitters released as part of the study design. The bias was ameliorated by adjusting the survival estimates for the probability of detecting dead fish with live transmitters, which reduced the estimated survival probabilities by about 0.02 .

The data and models indicated that the treatment effect was not fully expressed until the study reach terminating with Marshall Island Park on the Willamette River, a distance of 105.8 kilometers downstream of Cougar Dam. This was the first reach in which the 95-percent confidence interval of the estimated reach-specific relative survival overlapped 1.0, indicating similar survival of treatment and control groups. The median travel time of the treatment group from release to Marshall Island Park was 1.64 days during the November study and 1.36 days during the December study.

The survival probability of fish that passed into the RO was greater during the December study than during the November study. The relative survival probability of fish passing through the RO was 0.4594 (standard error [SE] 0.0543) during the November study and 0.7389 (SE 0.1160) during the December study. These estimates represent relative survival probabilities from release near Cougar Dam to the Marshall Island site.

The estimated survival probability of RO passage was lower than previous studies based on balloon and PIT tags, but higher than a similar study based on radio transmitters. We suggest that, apart from dam operations, the differences in survival primarily are due to the release location. We hypothesize that the balloon- and PIT-tagged fish released through a hose at a point near the RO gate opening experienced more benign conditions than the radio-tagged fish passing the RO volitionally. This hypothesis could be tested with further study. An alternative hypothesis is that some live fish remained within the study area beyond the life of their radio transmitter.

The results from these and previous studies indicate that entrainment and survival of juvenile salmonids passing Cougar Dam varies with dam operating conditions. The condition most conducive to dam passage has been the discharge and low pool elevation condition tested during December 2012. That condition included large RO gate openings and was the condition with the highest dam passage survival. 


\section{Introduction}

The U.S. Army Corps of Engineers (USACE) operates the Willamette Project (Project) located in western Oregon. The Project includes 13 dams, about $68 \mathrm{~km}$ of revetments, and several fish hatcheries. The dams, including Cougar Dam, are located on tributaries of the Willamette River. The primary purpose of the Project is flood control, but it also is operated to provide hydroelectricity, irrigation water, navigation, instream flows for wildlife, and recreation. A recent Biological Opinion determined that the Project jeopardizes the sustainability of anadromous fish stocks in the Willamette River Basin (National Oceanic and Atmospheric Administration, 2008).

Cougar Dam is a 158-m-tall rock-fill dam on the South Fork of the McKenzie River, located about $63 \mathrm{~km}$ east of Springfield, Oregon. The dam, completed in 1964, is owned and operated by the USACE. It has a hydraulic capacity of $1,050 \mathrm{ft}^{3} / \mathrm{s}$ and two Francis turbine units capable of generating a total of 25 megawatts. The dam also has a spillway with 2 Tainter gates, and a temperature control tower installed in 2005 that passes water to a flow-regulating outlet (RO) and to a powerhouse penstock through a common wet well. The reservoir primarily is used for flood control, and as such, the forebay elevation is maintained at high elevations during summer months and low elevations during winter months. Maximum conservation-pool elevation of 1,690 ft typically is reached in May, and the normal minimum flood-control pool elevation of $1,532 \mathrm{ft}$ is usually reached in December.

Juvenile salmon migrating downstream pass through the temperature control tower. The temperature control tower allows the use of water from various depths in the forebay to provide water temperatures suitable for salmon in areas downstream of the dam. All water passing through the dam enters the temperature control tower and passes to the tailrace either through the RO at a centerline elevation of 1,485.0 ft, or through the powerhouse penstock intake at a centerline elevation of 1,424.8 ft. At water elevations of 1,571.0 ft or greater, water passes over or between weir gates into the wet well of the temperature control tower and then through the RO or the penstock (fig. 1). At elevations lower than 1,571.0 ft, water can pass into the wet well through either the RO bypass gate (centerline elevation $1,488.5 \mathrm{ft}$ ) or the penstock bypass gate (centerline elevation 1,429.0 ft). A fish ladder and trapping facility are used to collect adult salmon in the tailrace for transportation upstream and provide a means of upstream passage for adult salmon. There is currently no passage route designed for downstream passage of juvenile salmon. 


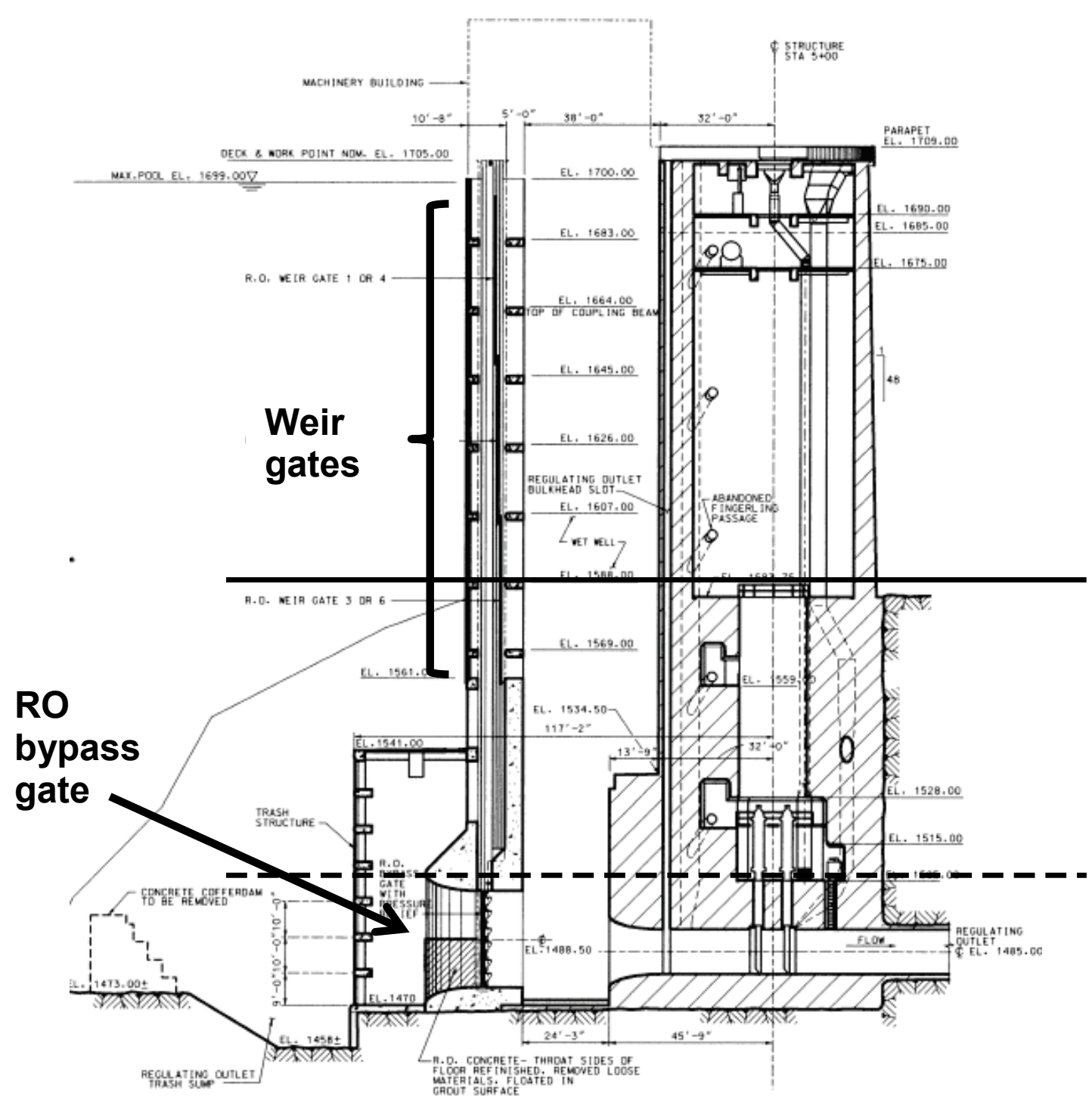

Figure 1. Cross-section of the temperature control tower at Cougar Dam, Oregon, showing the regulating outlet (RO) passage route. Horizontal lines indicate approximate average reservoir elevations during the release dates of the November (solid line) and December (dashed line) study periods. Schematic from U.S. Army Corps of Engineers.

The 2008 Willamette Biological Opinion requires improvements to operations and structures to reduce impacts on Upper Willamette River (UWR) Chinook salmon (Oncorhynchus tshawytscha) and UWR steelhead (O. mykiss) (National Oceanic and Atmospheric Administration, 2008). Among these improvements is a requirement to provide safe downstream passage for juvenile salmonids, a goal that may be achieved through operational or structural alternatives. Information about the probabilities of fish passage and survival through the RO and penstock routes during various dam operating conditions can be used to inform decisions about downstream passage alternatives. 
Several important factors affecting dam passage rates at Cougar Dam have been identified. A study of fish implanted with acoustic transmitters and released near the head of the reservoir showed that dam passage was positively related to diel period and dam discharge and negatively related to reservoir elevation (Beeman and others, 2013). Volitional dam passage rates at night were about nine times greater than during the day. As such, the greatest dam passage rates occurred at night during high discharge and low pool elevation. Data from radio-tagged fish released near the water surface at the temperature control tower corroborate the preponderance of night passage through the RO (Beeman and others, 2012).

Most studies have shown differences in passage survival through the two routes at Cougar Dam. In one study, fish tagged with a Hi-Z Turb-N-tag ${ }^{\circledR}$ (balloon tag) and a radio transmitter were used to estimate the paired-release direct survival of yearling Chinook salmon of hatchery origin during several dam operating conditions (Normandeau and Associates, Inc., 2010). The preliminary estimates of survival 48-h post-passage ranged from 36.4 to 42.4 percent for fish passing through the powerhouse, and 84.6 to 88.3 percent for fish passing through the RO, depending on the operating conditions. The highest survival through the RO was at the larger of the two gate openings tested $(3.7 \mathrm{ft})$. Monzyk and others (2011) estimated passage survival based on fish with passive integrated transponder (PIT) tags, and reported survival estimates for the RO route similar to those of the balloon-tagged fish and survival estimates for the powerhouse route greater than those of the balloon-tagged fish. Duncan (2011) passed sensor packages through the two routes and found more severe conditions within the powerhouse route than in the RO route, corroborating the results described by Normandeau and Associates, Inc. (2010) and Monzyk and others (2011). In November 2011, Beeman and others (2012) estimated that dam passage single-release survival of radio-tagged subyearling Chinook salmon from entry into the temperature control tower to detection at a site $3 \mathrm{~km}$ downstream was 0.3860 for fish passing through the powerhouse and 0.4247 for fish passing through the RO (expressed as probabilities rather than percentages). Based on these studies, novel dam operations were tested at Cougar Dam in 2012 in an effort to increase downstream passage probabilities and survival of juvenile Chinook salmon.

This report describes two studies conducted in 2012 designed to further examine the effects of dam operating conditions on fish passage and survival. The dam operating conditions differed during the two studies and were chosen based on evidence indicating greater survival and a preponderance of night passage through the RO route. The first study was conducted in November to estimate passage and survival probabilities during conditions of a high proportion of $\mathrm{RO}$ discharge during the night and a high proportion of powerhouse discharge during the day. These conditions enabled use of the powerhouse to generate electricity with the expectation of high passage rates at the RO and low passage rates at the powerhouse resulting in a survival advantage over previous operating conditions tested. The second was conducted in December at a reservoir elevation lower than the minimum required for operation of the powerhouse, which enabled all water to pass through the RO through the RO bypass gate and a large opening of the RO regulating gate. This condition was expected to result in high passage survival and a high probability of passing fish residing in the reservoir. The primary objectives of the studies were to estimate the passage probabilities through the available routes at Cougar Dam and to estimate the survival of fish passing through the RO. A secondary objective was to estimate reachspecific survival downstream from Cougar Dam to determine how long it took for the dam-passage effects to be fully expressed. As a tertiary objective, the study design also enabled estimates of the route-specific passage probabilities and the detection probability of the PIT detection system at Leaburg Dam on the McKenzie River downstream. 


\section{Methods}

\section{Dam Operations and Environmental Conditions}

Powerhouse discharge, RO discharge, forebay elevation, head over the temperature control tower weir gates, and water temperature data were summarized for November and December study periods to document the environmental conditions that the study fish experienced. Hourly powerhouse discharge, RO discharge, and forebay elevation data were obtained from the USACE website http://www.nwd-wc.usace.army.mil/perl/dataquery.pl? $k=i d: C G R$. Hourly temperature data were obtained from the USACE website http://www.nwdwc.usace.army.mil/tmt/documents/ops/temp/string_by_project.html. Weir elevation and RO gate opening data were provided by the USACE.

\section{Fish Capture, Handling, Tagging, and Release}

The data described in this report were collected from subyearling Chinook salmon implanted with radio transmitters and PIT tags. The tagged fish were of hatchery origin and were from the Wild Fish Surrogate project conducted by Oregon State University (Corvallis, Oregon). The fish were progeny of hatchery spring Chinook salmon that returned to the North Santiam River, Oregon, in the fall of 2011. The fish were fed either Abernathy Diet or Wild Chinook Grower Diet. Fish from each of the two diet groups were used in nearly equal numbers during each study period because there were not enough fish in either group for both study periods. Fish used in the November study were reared at the Fish Performance and Genetics Laboratory in Corvallis, Oregon. For the December study, fish fed Abernathy Diet were reared at the Fish Performance and Genetics Laboratory and fish fed Wild Chinook Grower Diet were reared at the Oregon Hatchery Research Center in Alsea, Oregon. Fish from the two combinations of feed type and rearing site will hereafter be called rearing group A (Abernathy Diet) and rearing group B (Wild Chinook Grower Diet).

The study fish were transported from the two rearing locations to Leaburg Hatchery in Leaburg, Oregon, about 2 weeks prior to the studies. For each study, about 900 hatchery Chinook salmon transported to the hatchery were placed in one of two outside circular ponds based on their rearing group. The ponds were supplied with flowing McKenzie River water. Once daily during November 4-8 and December 16-20, 2012, Chinook salmon of each rearing group were netted from the ponds, placed in separate $264 \mathrm{~L}$ transport tanks, and taken to the tagging site at the Cougar Dam adult fish facility. The fish remained in the tanks from 19.6 to $29.3 \mathrm{~h}$ prior to tagging during the November study and from 18.5 to $28.7 \mathrm{~h}$ during the December study. The same two taggers implanted radio transmitters and PIT tags during the November and December studies. The fish from the various release and rearing groups were divided nearly evenly between the two taggers each day.

The recommendations from the Surgical Protocol Steering Committee (2011) were followed in all aspects of fish holding, tagging, and releasing procedures. Tag implantation and fish recovery were completed at the Cougar Dam adult fish facility. Fish were considered suitable for tagging if they were free of major injuries, had no external signs of gas bubble trauma, major fin damage or fungus, were less than or equal to 20 percent descaled, had no visible signs of disease or deformities, and were not previously tagged with acoustic transmitters or PIT tags. In addition to these guidelines, we rejected fish over $180 \mathrm{~mm}$ fork length to better represent the size of wild fish in Cougar Reservoir during the fall. To implant the tag, fish were anesthetized using buffered tricane methane sulfonate (MS-222, Argent Chemical Laboratories, Redmond, Washington) at a concentration of 100-150 mg/L, depending on water temperatures. Fork length and weight were measured for every fish immediately prior to surgery. 
All weighing, measuring, and containment equipment were treated with a $0.25 \mathrm{~mL} / \mathrm{L}$ concentration of Stress Coat (Aquarium Pharmaceuticals, Inc., Chalfont, Pennsylvania) to reduce handling-related stress to the fish through electrolyte loss. Fish were placed in a $19 \mathrm{~L}$ perforated recovery bucket filled with $7 \mathrm{~L}$ of river water immediately after surgery. Dissolved oxygen levels were maintained between 80 and 110 percent of saturation during recovery. Each recovery bucket held up to three fish. Fish were watched periodically during the first 10 minutes after surgery to ensure they recovered from anesthesia. Recovery buckets were then fitted with numbered lids and placed in a raceway provided with flowing river water, where fish were held for 20.0 to $27.3 \mathrm{~h}$ prior to release in November and 18.6 to $27.7 \mathrm{~h}$ in December. The recovery buckets were floated in the raceway using rubber bicycle inner tubes fastened near the top to allow fish access to air in order to adjust their buoyancy (Fried and others, 1976). Throughout the entire tagging process, water quality was monitored in all transport tanks, pre-tag holding tanks, and the recovery raceway to ensure compliance with the Surgical Protocols Steering Committee (2011) guidelines.

The tagged fish were released twice daily at three release sites on each of 5 consecutive days during each study period (November 6-10 and December 18-22, 2012). The three different release sites were located (A) in the reservoir about $0.8 \mathrm{~km}$ upstream of the dam, (B) within a few meters of the upstream face of the temperature control tower, and (C) in the tailrace $0.2 \mathrm{~km}$ downstream of the dam (fig. 2). These groups will hereafter be called the reservoir, treatment, and control groups. Fish were released beginning at about 1:00 p.m. and 6:00 p.m. on each date. The treatment group was released near the middle temperature control tower trash rack (over the east RO gate) during the November study and near the RO bypass gate during the December study. To prepare for fish release, the recovery buckets were removed from the raceway, inspected for mortalities and functioning radio transmitters, and transferred into an insulated 1,556 L plastic tank. Two tanks were mounted on a flatbed trailer with lids to limit the amount of water spilling during transport. Each tank was filled about 50 percent with river water, and the fish recovery buckets were added and driven to either the boat ramp at the earthen dam, or along the riverbank slightly downstream of the convergence of the powerhouse and RO tailraces for release. The reservoir and treatment groups were transferred at the boat ramp from the insulated transport tanks onto a boat where they were driven to their release locations. The reservoir group was released by partially submerging the buckets in the reservoir and gently tipping them over. The treatment fish were taken to a floating platform secured at the southeastern corner of the temperature control tower and released by gently pouring the recovery bucket contents into a conical-bottom tank provided with flowing reservoir water connected to $9.1 \mathrm{~m}$ of $7.6 \mathrm{~cm}$-diameter polyvinyl-chloride (PVC) pipe that terminated about $1 \mathrm{~m}$ deep in front of the middle trash rack (fig. 3). The control group was released into a tank and pipe system similar to that used for the treatment fish, except the PVC pipe was $12.2 \mathrm{~m}$ long and the fish exited the pipe about $0.3 \mathrm{~m}$ above the water surface. There also were 25 euthanized Chinook salmon with live radio and PIT tags released in the tailrace during each study to test one of the survival model assumptions (see section "Estimating Passage, Detection, and Survival Probabilities"). Water quality measurements were recorded at all release locations prior to release to ensure the water temperature difference between the recovery bucket and the reservoir was not greater than $2^{\circ} \mathrm{C}$, which would require tempering per the Surgical Protocols Steering Committee (2011). 


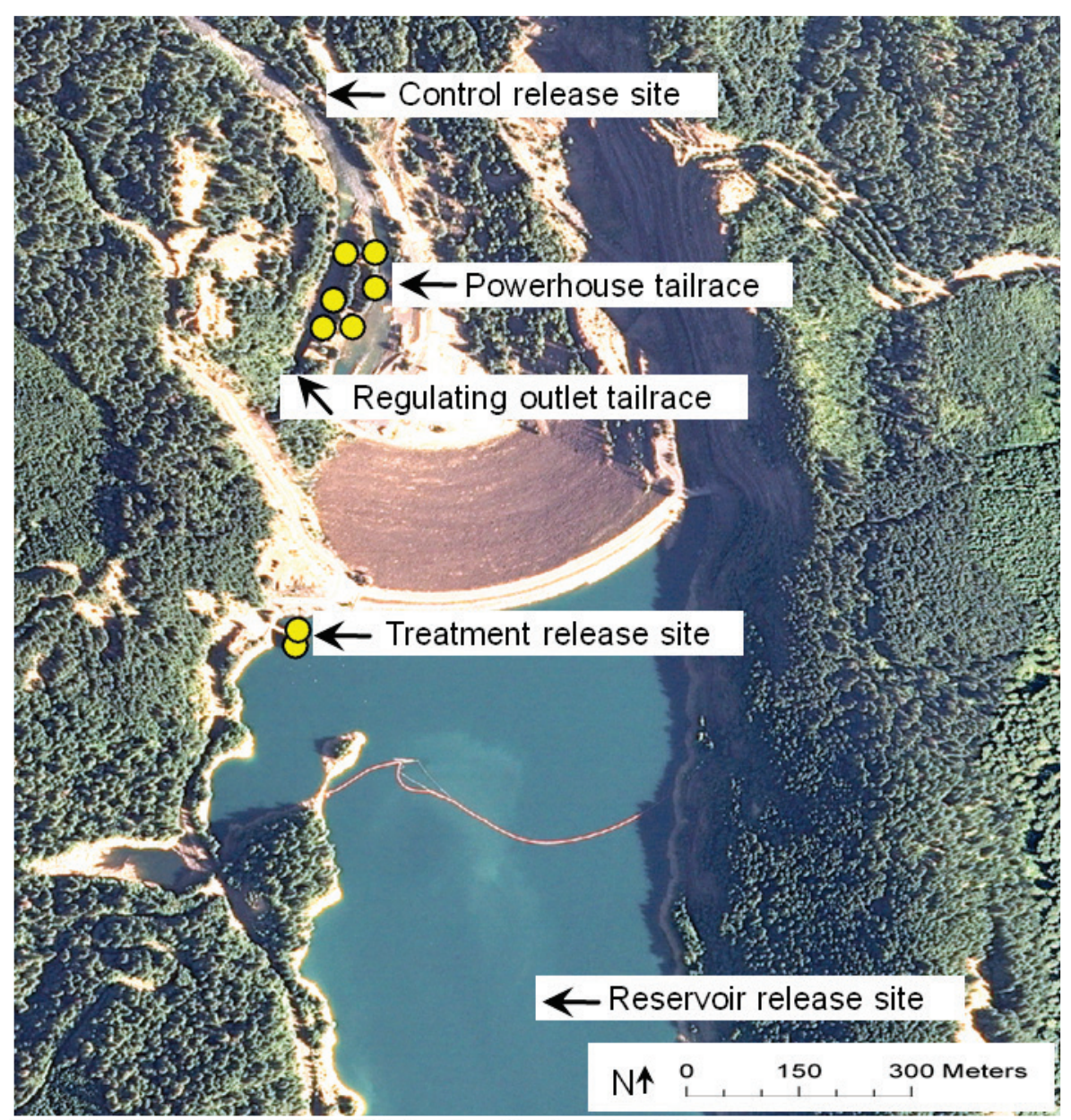

USGS High Resolution State Orthoimagery for Oregon, 2011, 0.5 meter resolution

Figure 2. Schematic of release locations and radio-telemetry-antenna sites (circles) near Cougar Dam, Oregon, during the November and December 2012 studies. 


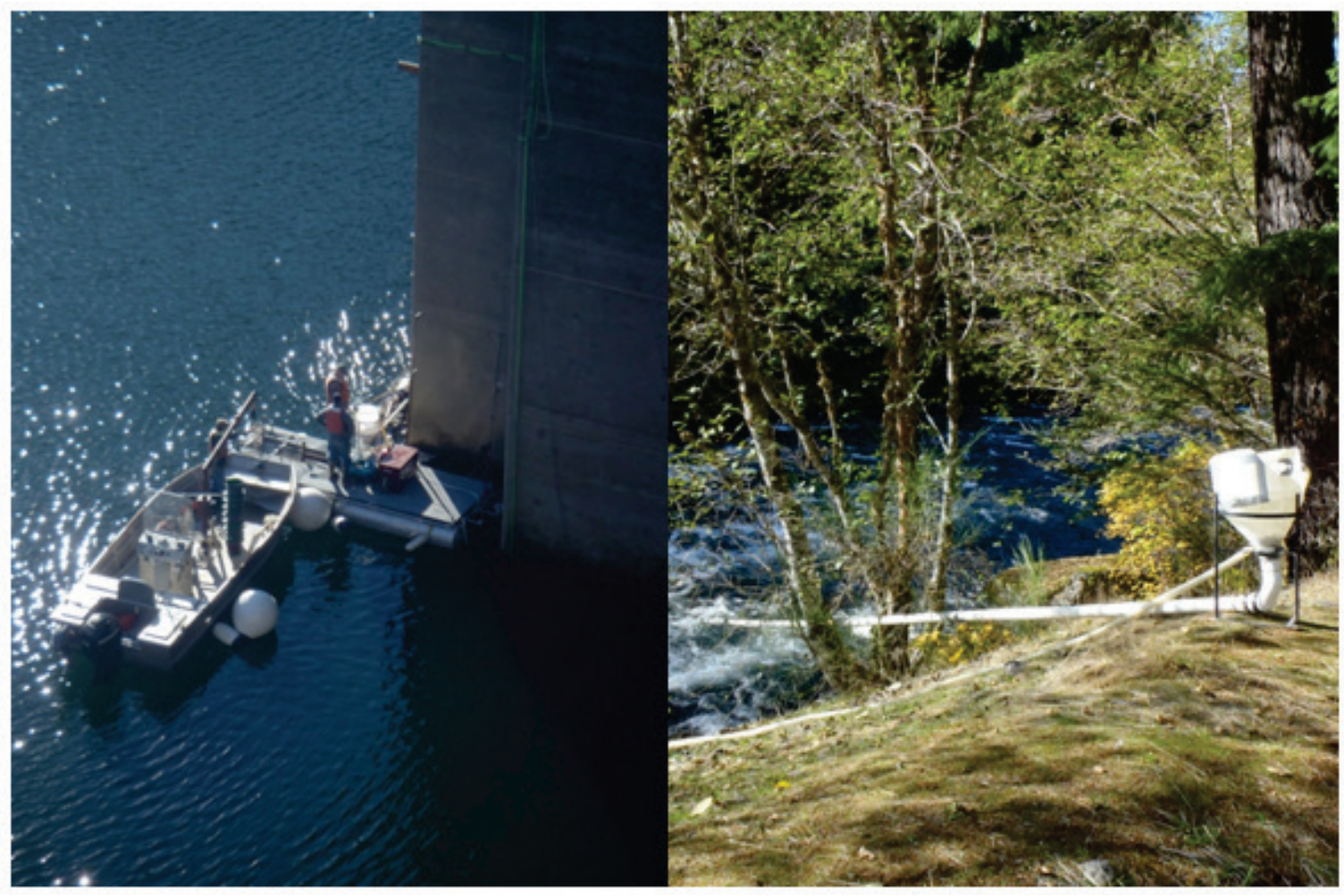

Figure 3. Photographs of fish release systems for the treatment (left) and control (right) groups at Cougar Dam, Oregon. Photographs by John W. Beeman, U.S. Geological Survey.

\section{Radio Transmitters}

The studies were based on data from detections of the implanted radio transmitters and PIT tags. The radio transmitters used in this study had dimensions in millimeters of 10 long $\times 5$ wide $\times 3$ deep; mass $(\mathrm{g})=0.31$ in air, and they had a 16-cm trailing antenna (Lotek Wireless model NTQ-2, Newmarket, Ontario, Canada). Typical transmitter life, as stated by the manufacturer, was expected to be about 31 days given the transmission intervals of 4.8, 4.9, 5.0, 5.1, or 5.2 seconds. Several transmission intervals were used to increase the probability of detection if many transmitters were in the same detection field together. The transmitters were nearly equally divided among operating frequencies of 166.300, 166.340, 166.360, and 166.380 MHz and emitted pulse-coded transmissions. A $12 \mathrm{~mm}$ long full-duplex PIT tag weighing $0.10 \mathrm{~g}$ was placed inside the body cavity along with the radio transmitter to enable detection at any of the pre-existing PIT detectors operated by other entities downstream of Cougar Dam. 


\section{Radio-Telemetry Detection Systems}

Radio-telemetry receiving systems were installed at several sites between the forebay of Cougar Dam and the Willamette River near its confluence with the Santiam River (fig. 4). The sites were chosen to divide the study area into logical reaches based on confluences of major rivers and specific areas of interest (for example, Leaburg Dam) and to be consistent with sites used by Beeman and others (2012) where possible. The distances between the sites ranged from 0.2 to $106.8 \mathrm{~km}$ (table 1). Most sites consisted of at least one 3-element Yagi aerial antenna providing a single balanced input into one or more narrow-band receivers (Evans and Stevenson, 2012; table 1). The narrow-band receivers were Lotek Wireless models SRX-400 or SRX-600 (Newmarket, Ontario, Canada). Narrow-band receivers scanned each of the four frequencies for 5.6 seconds on a repeating cycle. Antennas inside the temperature control tower and the site in the fish bypass at Leaburg Dam were underwater strippedcoaxial-cable types (Beeman and others, 2004) providing at each site a single balanced input to a wideband receiver scanning all frequencies simultaneously (model Orion, Sigma8, Newmarket, Ontario, Canada). The receiver inside the temperature control tower was changed to a narrow-band type shortly after the start of the November study. Detection systems in the tailraces of Cougar Dam and Leaburg Dam as well as the furthest downstream site (Hops Farm) were 'double array' systems providing two independent detection systems with which to estimate detection probabilities for each passage route, or at the final detection array.

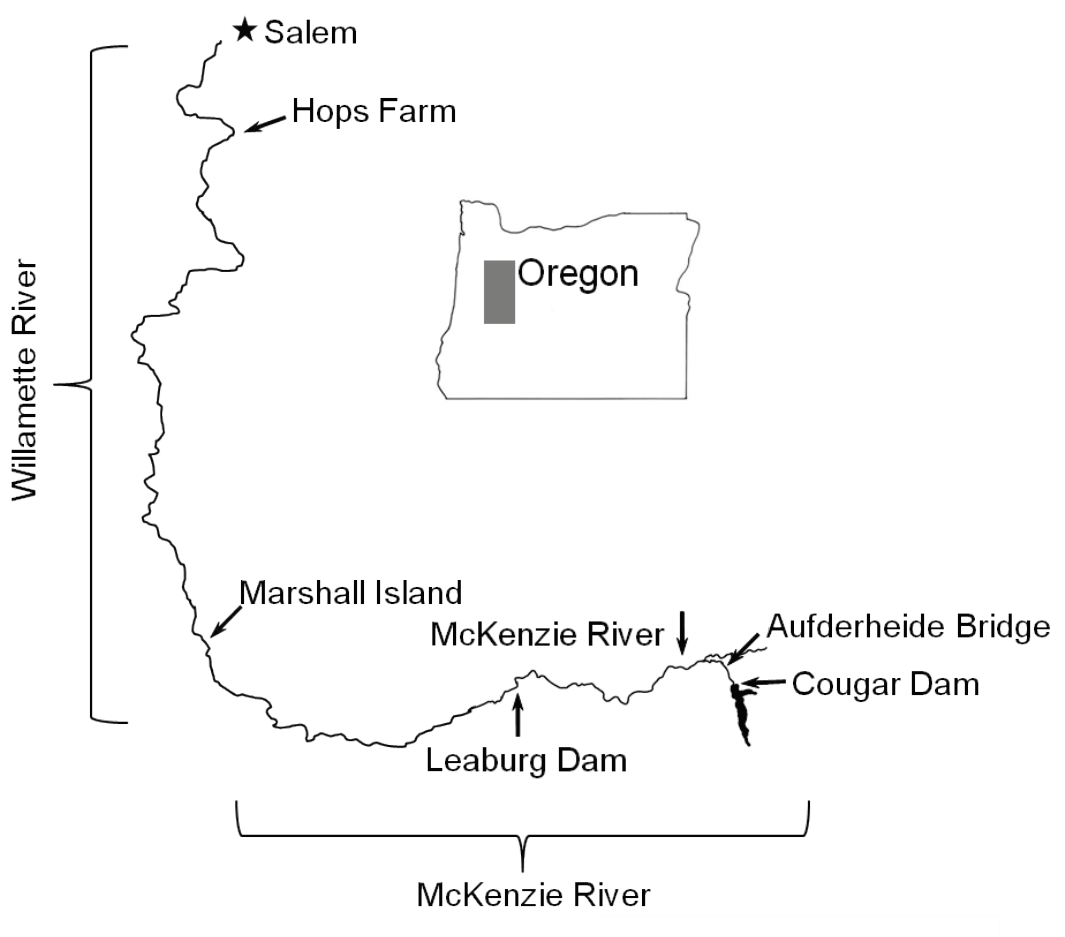

$\mathrm{N \uparrow} \stackrel{0}{0} \quad \mathbf{7 . 5}, 15, \ldots$ Kilometers

Figure 4. Schematic of study area showing radio-telemetry detection sites downstream of Cougar Dam, Oregon, used during the November and December 2012 studies. 
Table 1. Summary of radio-telemetry detection sites.

[Spatial coordinates of the sites are listed in appendix A. na, not applicable]

\begin{tabular}{|c|c|c|c|}
\hline \multirow[b]{2}{*}{ Site No. } & \multirow[b]{2}{*}{ Site name } & \multicolumn{2}{|c|}{ Kilometers from } \\
\hline & & $\begin{array}{c}\text { Site } \\
\text { upstream }\end{array}$ & $\begin{array}{c}\text { Cougar } \\
\text { Dam }\end{array}$ \\
\hline 1 & Forebay & na & -0.2 \\
\hline 2 & Inside Temperature Control tower & 0.2 & 0.0 \\
\hline 3 & Powerhouse tailrace $^{1}$ & 0.5 & 0.5 \\
\hline 4 & Regulating outlet tailrace $^{1}$ & 0.5 & 0.5 \\
\hline 5 & South Fork McKenzie River at Aufderheide Road Bridge & 3.0 & 3.5 \\
\hline 6 & McKenzie River near South Fork McKenzie River & 5.5 & 9.1 \\
\hline 7 & McKenzie River at Leaburg Dam & 31.1 & 40.2 \\
\hline 8 & Willamette River at Marshall Island Park & 65.6 & 105.8 \\
\hline 9 & Willamette River at Rogue Hops Farm & 106.8 & 212.6 \\
\hline
\end{tabular}

${ }^{1}$ Approximate distance from temperature control tower.

\section{Passive Integrated Transponder-Tag Detection System at Leaburg Dam}

The full-duplex PIT-detection system in the screened smolt-bypass channel at Leaburg Dam is on the western side of the McKenzie River slightly downstream of Leaburg Dam and consists of three coils. The site is owned and operated by the Eugene Water and Electric Board. PIT-tagged fish may be detected automatically at the series of three PIT coils in the bypass or by manually scanning fish collected in a rotary screw trap mounted inside the bypass. The trap is operated periodically by Oregon Department of Fish and Wildlife (ODFW) staff. Further information about the site is available at http://www.ptagis.org/sites/interrogation-site-metadata under the site code LEA.

\section{Data Management and Analysis}

\section{Removing False-Positive Records}

Records from the radio-telemetry receivers suspected of being false-positive detections were removed prior to analysis. False-positive detections are those that indicate presence of a transmitter when it is not present and are possible in all telemetry systems. Common causes of false-positive detections are overlapping transmissions of multiple transmitters creating a pattern of another transmitter, and ambient noise doing the same, with or without the presence of telemetry transmitters. Several commonly used steps were implemented to reduce the probability of false-positive detections in the data (Skalski and others, 2002; Beeman and Perry, 2012). The series of steps we used were similar to those of "Method B" described by Beeman and Perry (2012), and were chosen to minimize the number of spatiotemporal errors requiring human intervention and the number of true positives removed. First, only records from transmitters released as part of the study occurring after their time of release were retained. Second, only records within the maximum empirically determined transmitter life were retained. A transmitter life of 73 days was used, based on results of the transmitter life tests from the November study, because the transmitter life test from the December study was not complete until April 2013. Third, a minimum received power threshold equal to the 75th percentile of receiver-specific received power of false positive records (those not consistent with the first step) over the study period was applied. Fourth, a criterion of a minimum number of sequential detections (detections of sequential 
tag transmissions) was applied. This step was similar to methods C-E in Beeman and Perry (2012), but was modified for use with narrow-band receivers. During the November study, the minimum number of sequential detections for a valid record was 2, except for the Cougar Dam and Leaburg Dam tailraces and Cougar Dam forebay sites (minimum number of 3 ) and the site inside the temperature control tower (minimum number of 4). During the December study, the minimum number of sequential detections for a valid record was 2, except for the Aufderheide Bridge site (minimum number of 3), and the site inside the temperature control tower (minimum number of 4). A greater number of consecutive records were required at sites with more ambient noise.

\section{Assigning Route and Time of Passage}

The route of passage was assigned based on the location and time of the first detection of fish at the radio-telemetry arrays immediately downstream of Cougar or Leaburg Dams. Fish that were not detected by radio-telemetry arrays in the Cougar Dam tailraces but were captured in rotary-screw traps in the tailraces were not assigned a passage route based on the trap location, because Beeman and others (2012) found that some radio-tagged fish moved between tailraces prior to traveling downstream, which indicated that capture in a trap was not an absolute measure of their route of passage. Fish detected in the fish bypass at Leaburg Dam were always assigned that route of passage even if they also were detected with the antennas at the spillway, because underwater antennas in the bypass have very short ranges compared to the aerial antennas at the spillway.

\section{Estimating Travel Times}

The time elapsed between and among detection sites was described using the Kaplan-Meier survivorship function (Hosmer and Lemeshow, 1999). The travel time between any two detection sites was estimated as the time from the last detection at the upstream site to the first detection at the downstream site. The survivorship function of a variable $\mathrm{T}$ is defined as

$$
\mathrm{S}(\mathrm{t})=\operatorname{Pr}\{T>t\},
$$

where $\mathrm{T}$ is a random variable with a probability distribution, denoting an event time for an individual. If the event of interest is passing a particular site, the survivorship function gives the probability of not passing the site after time $t$. As such, the median time occurs when the survivorship function equals 0.5 . In the absence of censoring, the survivorship function represents the proportion of the population that has not experienced an event (for example, passing a site). Examining the survivorship function can be useful to describe the timing of events as well as the proportion of the population still at risk of the event at different points in time. To estimate multiple-reach travel times, incomplete detection histories were right censored at the last time of detection at the nearest upstream site.

\section{Estimating Passage, Detection, and Survival Probabilities}

Cormack-Jolly-Seber (CJS) mark-recapture methods were used to estimate passage, detection, and survival probabilities (Cormack, 1964; Jolly, 1965; Seber, 1965). Detection of a tagged animal is the product of the probability of presence and the probability of detection, so these parameters must be separately estimated. The Route-Specific Survival Model (RSSM) of Skalski and others (2002) was used to estimate passage, detection, and survival parameters of interest. Parameters of interest and profile-likelihood confidence intervals were estimated using maximum-likelihood techniques with the User-Specified Estimation Routine software (version 4.7.0, Powell's Direction Set optimizer; Lady and Skalski, 2009). 
The paired-release design was used to estimate survival. The term "paired-release" refers to the use of one or more releases of fish made at two locations to enable a paired, or "relative" survival of a treatment and control group. The goal of relative survival estimates is typically to restrict the area of inference to the spatial area between release of the treatment and control group and also as a means to control for tag and handling effects (Burnham and others, 1987). A schematic of the model structure is in figure 5 .

Survival and detection probabilities from the RSSM are subject to 11 assumptions. The assumptions as described by Skalski and others (2002) are:

1. Individuals marked for the study are a representative sample from the population of interest.

2. Survival and capture probabilities are not affected by tagging or sampling. That is, tagged animals have the same survival probabilities as untagged animals.

3. All sampling events are "instantaneous." That is, sampling occurs over a negligible distance relative to the length of the intervals between sampling events.

4. The fate of each tagged individual is independent of the fate of all others.

5. All tagged individuals alive at a sampling location have the same probability of downstream survival.

6. All tagged individuals alive at a sampling location have the same probability of being detected.

7. All tags are correctly identified and the status of smolt (that is, alive or dead) is correctly assessed.

8. Survival in the lower river segments is conditionally independent of survival in the upper river segments.

9. Both the upstream and downstream release groups within a paired release experience the same survival probability in the segment of the river that they travel together.

10. Routes taken by the radio-tagged fish through the project are known without error.

11. Detection in the primary and secondary antenna arrays within a passage route is independent.

Assumption 1 states the study animals should represent the animals of interest. In these studies, we used juvenile Chinook salmon from the Wild Fish Surrogate project, which were similar in size to wild fish in the reservoir. 


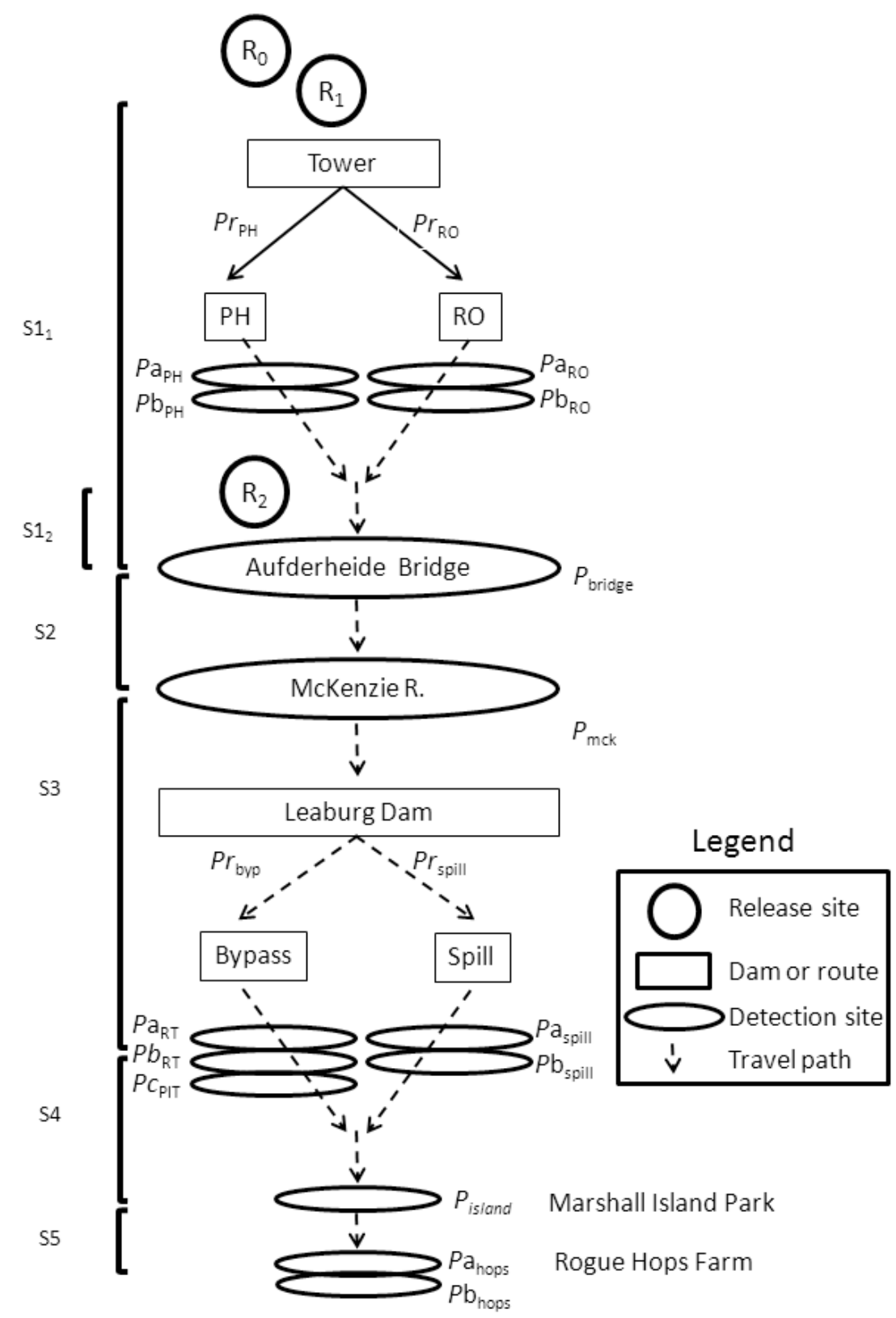

Figure 5. Schematic of the Route Specific Survival Model structure used to estimate detection, passage, and survival probabilities. PH is Cougar Dam powerhouse, RO is Cougar Dam regulating outlet at Leaburg Bypass, RT is radio- telemetry detector, and PIT is passive integrated transponder detector. $\mathrm{Pr}$ indicates passage probabilities, $P$ indicates detection probabilities, $S$ indicates survival probabilities. $R_{0}, R_{1}$, and $R_{2}$ denote reservoir, treatment, and control group release sites, respectively. Dashed travel paths indicate route-specific detection and survival parameters based on passage route at Cougar Dam that were omitted for clarity. All parameters are duplicated for day and night operating periods at Cougar Dam. Not to scale. 
Assumptions 2, 7, and 9 were formally examined. Assumption 2 is about tag and handling effects and was assessed by examining the data for differences in single-release survival estimates of fish tagged by each of the two taggers using Program MARK (White and Burnham, 1999). Support of models describing hypotheses of (a) tagger effects and (b) no tagger effects were assessed using the Akaike Information Criterion (Burnham and Anderson, 2002). The log-link function was used in these models. Assumption 7 was assessed by releasing euthanized fish with live transmitters at the control release site to test for false positives (detecting dead fish with live transmitters downstream) and by comparing transmitter lives to fish travel times to test for false negatives (premature transmitter failure). Violations of this assumption from false positives can be overcome by omitting the offending detection site and those upstream (Beeman and others, 2010), or by adjusting the estimated survival for the probability of detecting a dead fish with a live transmitter (Skalski and others, 2013b). The probability of false negatives was assessed by empirically determined transmitter lives and comparing them to fish travel times to estimate the probability of a transmitter functioning while the fish were in the study area using methods of Townsend and others (2006). Assumption 9 was examined by (a) comparing travel times and migration timing of control and treatment groups at each detection site, and (b) estimating the 95-percent confidence interval of reach-specific relative survival. The assumption was deemed to be satisfied for a study reach based on the latter criterion when the estimated 95-percent confidence interval of the reach-specific relative survival overlapped 1.0. The remaining assumptions generally are met in most studies using active tags. For example, Assumptions 3, 5, 10, and 11 are typically met due to the passive nature and large ranges common to radio telemetry.

The survival estimated in this and other studies in which the fate of animals is not directly observed is termed "apparent survival" (Burnham and others, 1987). Apparent survival is the probability that an animal remains available for recapture, or more specifically "detection," in the context of this study. In this study, it is the joint probability that the animal is alive and migrates through the study area. As such, fish that leave the study area undetected and do not return, stop migrating downstream during the life of their transmitters, or whose tags stop transmitting before they travel through the entire study area are counted as mortalities. Hereafter the term "survival" in this report refers to apparent survival.

Summarized detection histories make up the basic input for the mark-recapture model and are used in the estimation procedure. In general, the passage, detection, and survival probabilities are derived by estimating the probability of each possible detection from the observed frequencies of each detection history, and using maximum-likelihood methods to find parameter estimates of survival, passage, and detection probabilities that are most likely to occur, given the observed data. The RSSM uses a primary likelihood to estimate survival and passage probabilities and auxiliary likelihoods to estimate independent route-specific detection probabilities. The auxiliary likelihoods are based on detections at a primary and secondary detection array in each tailrace of Cougar Dam, the tailrace of Leaburg Dam, and at the farthest downstream site (Hops Farm), commonly referred to as a 'double array.' Alternatively, route-specific detection probabilities may be estimated for one route using CJS methods based on detections downstream while the other routes are estimated using the auxiliary likelihoods. The detection probabilities at sites downstream of the Cougar Dam tailraces were assumed to be equal for fish from the two rearing groups and those passing the spillway or bypass at Leaburg Dam were assumed to be equal downstream of Leaburg Dam. Model selection uncertainty was assessed by comparing competing models of survival, passage, and detection probabilities due to the large number of potential parameters given the various routes, dams, rearing groups, and detection sites (Burnham and Anderson, 2002; Skalski and others, 2013a). 


\section{Results}

Several fish were omitted prior to analysis. These included 26 from the November study and 20 from the December study that were collected in the ODFW RO tailrace screw trap and then examined non-lethally by USGS personnel for any maladies. Of the 26 Chinook salmon from the November study, three had hemorrhaged eyes and one was dead upon ODFW staff arrival at the trap. Three of the 20 Chinook salmon collected for the December study had damage to an operculum, three had hemorrhaged eyes or bodily injury, one was descaled and one was dead upon ODFW staff arrival at the trap. The fish examined were released into the tailrace, but were not included in analyses of passage and survival probabilities.

\section{Fish Capture, Handling, Tagging, and Release}

A total of 788 hatchery tagged Chinook salmon were released from November 6 to 10, 2012, and 718 were released from December 18 to 22, 2012, not counting the fish examined from the screw traps in the Cougar Dam RO tailrace. The allocation of effort among taggers as well as the numbers, sizes, and release times of the fish released are summarized in appendix B. The allocation of effort between taggers among the various release dates, times, rearing groups, and release sites was nearly equal. The fish released during the November study averaged $148.2 \mathrm{~mm}$ in fork length (FL; range 105-179 mm) and $35.7 \mathrm{~g}$ in weight (range 12.7-68.6 g). The fish released during the December study averaged 160.9 in FL (range 112-180 $\mathrm{mm}$ ) and $44.4 \mathrm{~g}$ in weight (range 15.2-72.3 g). The tag burden based on the 0.41 $\mathrm{g}$ combined weight of the radio transmitter and PIT tag ranged from 0.6 to 3.2 percent with an average of 1.2 percent in the November study and ranged from 0.6 to 2.7 percent with an average of 1.0 percent in the December study. During the November study, 2.5 percent of the fish available were rejected from tagging, and 0.7 percent of the total was due to fish being greater than $180 \mathrm{~mm}$ FL. In the December

study, 17.4 percent of the fish available were rejected from tagging and 15.2 percent of the total was due to fish being larger than $180 \mathrm{~mm}$ FL. There were no mortalities in the pre-tag or post-tag holding periods. The 25 euthanized tagged fish released during the November study had an average FL of 150.1 $\mathrm{mm}$ (range 127-174 $\mathrm{mm}$ ) and an average weight of $36.3 \mathrm{~g}$ (range 21.7-56.2 $\mathrm{g}$ ). The 25 euthanized tagged fish released during the December study had an average FL of $155.8 \mathrm{~mm}$ (range 124-180 $\mathrm{mm}$ ) and an average weight of $41.4 \mathrm{~g}$ (range 19.6-64.6 g).

Fish sizes were similar among release sites, treatment and controls groups, and live versus euthanized fish groups, but they differed between rearing groups and study periods. Results of two-way General Linear Models (GLM) of release group and study period indicated there was no significant difference in FL between reservoir, treatment, and control groups in either study period $(P=0.9461)$, but the FL at tagging of those released in November was smaller than those released in December $(P<$ 0.0001). The FLs of fish sacrificed prior to release and those of the treatment and control fish released alive were not significantly different (two-way GLM, $P=0.4268$ ). Fish from the two rearing groups differed slightly in FL at tagging in each of the study periods and had similar travel times and survivals. Comparisons of the fish from the two rearing groups are described in appendix C.

\section{Environmental Conditions}

The environmental conditions during each study period were summarized over two time periods. This was required because the fish released in the reservoir to estimate Dam Passage Efficiency (DPE) passed the dam over a longer time period than those used to estimate survival, which passed almost exclusively on the dates of release. 


\section{Passage Dates Used to Estimate Dam Passage Efficiency}

Dam passage of the fish released in the reservoir was used to estimate DPE. The dam operating conditions during the period of dam passage are summarized in appendix D and are described briefly here.

The dam operating conditions during the November study between the first release on November 6, 2012, and the last known passage date of fish released in the reservoir on December 23, 2012, generally consisted of decreases in forebay elevation and water temperature, and a variety of dam discharges (fig. 6). Over this period, the forebay elevation generally decreased from a high of $1595.4 \mathrm{ft}$ to a low of $1504.0 \mathrm{ft}$, and averaged $1550.8 \mathrm{ft}$; the hourly average water temperature of the upper 13-18 $\mathrm{ft}$ of water decreased from 8.1 to $5.0^{\circ} \mathrm{C}$, and averaged $6.8^{\circ} \mathrm{C}$. The total discharge ranged from 910.0 to $6,780.0 \mathrm{ft}^{3} / \mathrm{s}$, with an average of $2,325.9 \mathrm{ft}^{3} / \mathrm{s}$ during the day, and ranged from 780.0 to $4,040.0 \mathrm{ft}^{3} / \mathrm{s}$, with an average of $2,306.2 \mathrm{ft}^{3} / \mathrm{s}$ during the night.
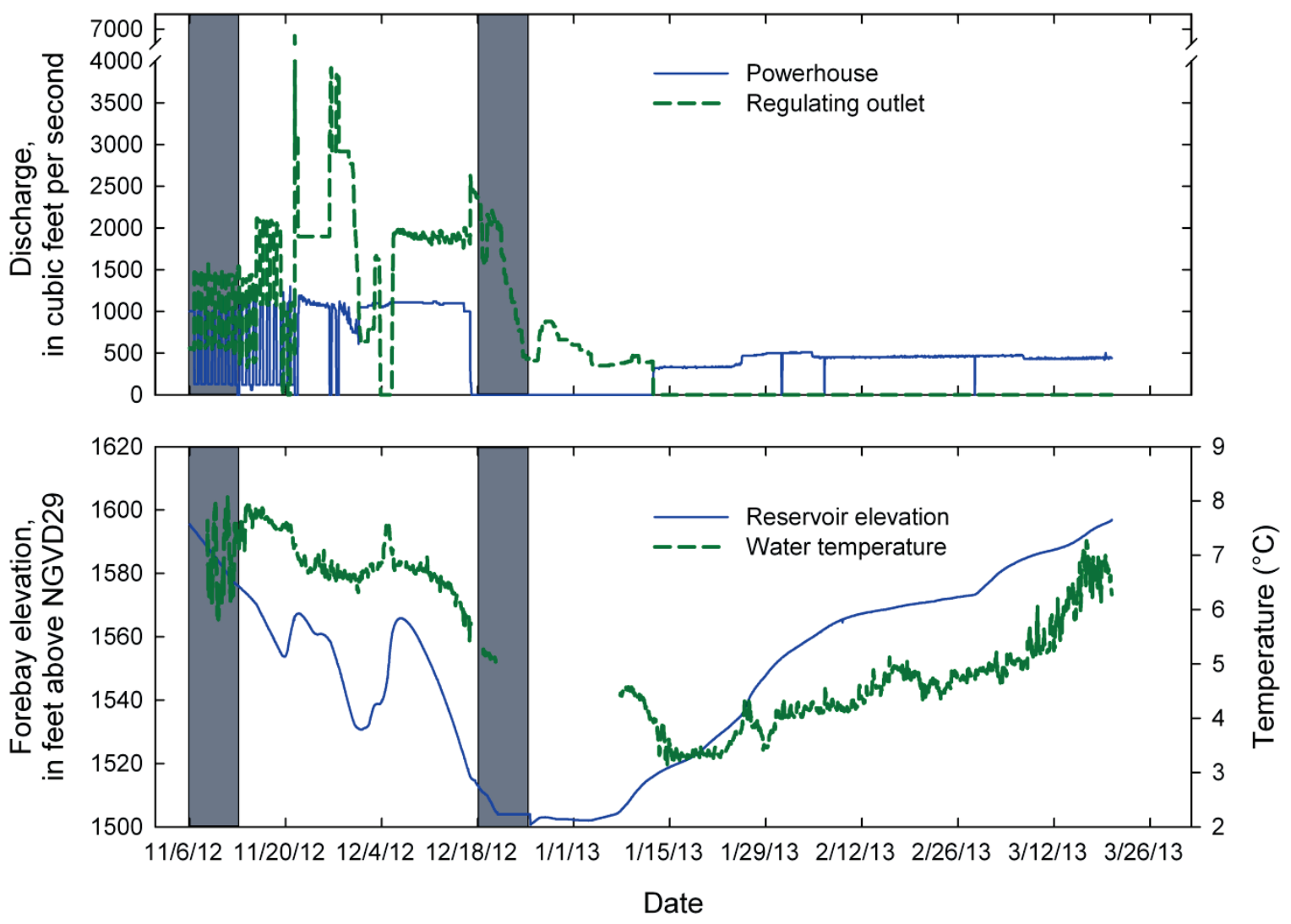

Figure 6. Graphs showing environmental conditions at Cougar Dam, Oregon, during the November and December 2012 studies. The periods of fish releases (November 6-10 and December 18-22) are shaded. The reservoir elevation was lower than the water temperature sensors from December 20, 2012, at 3 p.m. to January 7, 2013, at 7 p.m. 
The dam operating conditions during the December study between the first release on December 18 , 2012, and the last known passage date of fish released in the reservoir of February 22, 2013, included the planned operation of low reservoir elevation and all water passing through the RO (no turbine discharge) followed by a period of less constrained operations (fig. 6). The reservoir elevation declined during the beginning of this period, but began to rise in late December. The mean forebay elevation was $1,528.9 \mathrm{ft}$ and the elevation ranged from 1500.7 to $1569.3 \mathrm{ft}$. Water temperature ranged from 3.1 to $5.3^{\circ} \mathrm{C}$, with a mean of $4.0^{\circ} \mathrm{C}$. Temperature data were not available between December 20,2012 , at 3 p.m. and January 7, 2013, at 7 p.m. because the forebay elevation was lower than the temperature sensors. The total discharge ranged from 270.0 to $2,290.0 \mathrm{ft}^{3} / \mathrm{s}$ with an average of $561.9 \mathrm{ft}^{3} / \mathrm{s}$ during the day and ranged from 310.0 to $2,370.0 \mathrm{ft}^{3} / \mathrm{s}$ with an average of $585.0 \mathrm{ft}^{3} / \mathrm{s}$ during the night. The powerhouse was off from December 18, 2012, to January 12, 2013.

Discharge in the McKenzie and Willamette Rivers during the migration of most tagged fish was higher during the December study than during the November study. Discharge of the McKenzie River near Vida, Oregon, upstream of Leaburg Dam (USGS gage 14162500) averaged 4,371 $\mathrm{ft}^{3} / \mathrm{s}($ range 4,410-5,080 $\left.\mathrm{ft}^{3} / \mathrm{s}\right)$ between November 6 and 19, 2012, and averaged 5,790 $\mathrm{ft}^{3} / \mathrm{s}$ (range 4,110-8,380 $\left.\mathrm{ft}^{3} / \mathrm{s}\right)$ between December 18 and 31, 2012. Discharge in the Willamette River near Salem, Oregon (USGS gage 14191000), averaged 24,421 $\mathrm{ft}^{3} / \mathrm{s}$ (range $21,100-35,600 \mathrm{ft}^{3} / \mathrm{s}$ ) between November 6 and 19, 2012 , and averaged 56,114 $\mathrm{ft}^{3} / \mathrm{s}$ (range 35,400-66,600 $\mathrm{ft}^{3} / \mathrm{s}$ ) between December 18 and 31, 2012.

\section{Passage Dates Used to Estimate Dam Passage and Survival Probabilities}

Fish from the treatment group passing Cougar Dam on the dates of release were used to estimate passage and survival probabilities. The dam operating conditions during those periods are summarized in appendix D and are described briefly here.

During the release dates of the November study, the dam operation was similar to the planned condition (fig. 6). The forebay elevation over the release dates of November 6-10, 2012, declined from $1,595.4$ to $1,581.6 \mathrm{ft}$ and averaged $1,588.6 \mathrm{ft}$; at these elevations, all water entering the temperature control tower passed through the weir gates (fig. 1). The total discharge ranged from 1,540.0 to 1,600.0 $\mathrm{ft}^{3} / \mathrm{s}$, with an average of $1,574.7 \mathrm{ft}^{3} / \mathrm{s}$ during the day, and ranged from $1,520.0$ to $1,710.0 \mathrm{ft}^{3} / \mathrm{s}$, with an average of 1,561.4 $\mathrm{ft}^{3} / \mathrm{s}$ during the night. Per the planned operation, the average powerhouse discharge was higher during the day $\left(1,000.0 \mathrm{ft}^{3} / \mathrm{s}\right)$ than at night $\left(228.0 \mathrm{ft}^{3} / \mathrm{s}\right)$, and the average $\mathrm{RO}$ discharge was lower during the day $\left(547.7 \mathrm{ft}^{3} / \mathrm{s}\right)$ than at night $\left(1,333.4 \mathrm{ft}^{3} / \mathrm{s}\right)$. The mean RO gate number 2 opening was $1.21 \mathrm{ft}$ during the day and $3.18 \mathrm{ft}$ during the night. The RO gate number 1 was closed during the November study except for a brief period on November 6, 2012, when it was open $1.0 \mathrm{ft}$, and RO gate number 2 was open $2.0 \mathrm{ft}$. The mean hourly temperature of the top $13-18 \mathrm{ft}$ of the reservoir measured at the temperature control tower averaged $6.7^{\circ} \mathrm{C}$ (range $5.8-8.0^{\circ} \mathrm{C}$ ).

During the release dates of the December study, the dam operating conditions were as planned. The powerhouse was off, due to the low forebay elevation, and all water passed through the RO from December 18 through 22, 2012. The forebay elevation generally declined from 1,513.0 to 1,504.0 ft and the mean was $1,506.9 \mathrm{ft}$. The RO discharge ranged from $1,160.0$ to $2,370.0 \mathrm{ft}^{3} / \mathrm{s}$ with a mean of $1,820.8$ $\mathrm{ft}^{3} / \mathrm{s}$, and decreased shortly after the releases began, increased sharply, and then decreased over the remainder of the time period. The RO discharge was similar during the day and night. The mean RO gate number 2 opening was $7.34 \mathrm{ft}$ during the day and $7.55 \mathrm{ft}$ during the night. RO gate number 1 was open $0.95 \mathrm{ft}$ throughout the period. The range of water temperature in the upper 13-18 $\mathrm{ft}$ of the reservoir was $5.0-5.3^{\circ} \mathrm{C}$ with a mean of $5.1^{\circ} \mathrm{C}$. The weir gates were not in use during the December releases, and all water passing through the temperature control tower entered through the RO bypass gate (fig. 1). 


\section{Timing of Dam Passage}

Dam passage timing was evaluated using fish released in the reservoir to represent volitionally migrating fish. Most fish released into the reservoir passed the dam during the night (fig. 7). During the November study, 94.8 percent of the dam passage of these fish occurred during the night (between sunset and sunrise), and during the December study, 93.8 percent of their passage occurred during the night (table 2). The diel passage percentages of fish released during the day were similar to those released at night. The percentage of fish released in the reservoir that passed the dam during the life of the transmitter, an estimate of DPE, was 70.1 percent during the November study and 71.4 percent during the December study. The median time from release to dam passage was 9.3 days (range $0.1-46.3$ days) during the November study and 1.0 days (range 0.2-55.2 days) during the December study (fig. 8). In the November study, it took 37.0 days for at least 90 percent of the passage to occur and in the December study it took 6.9 days. For comparison, in the November study, 41 percent of the fish passed within 6.9 days. In November, most volitional passage was through the RO route, although 44 percent of the fish that passed were not detected in the tailraces and thus no passage route was assigned. Of the fish with known passage routes, 92.1 percent passed through the RO, and 7.9 percent passed through the powerhouse during the November study. All fish passage during the December study was through the $\mathrm{RO}$, because the powerhouse did not operate during most of that study.

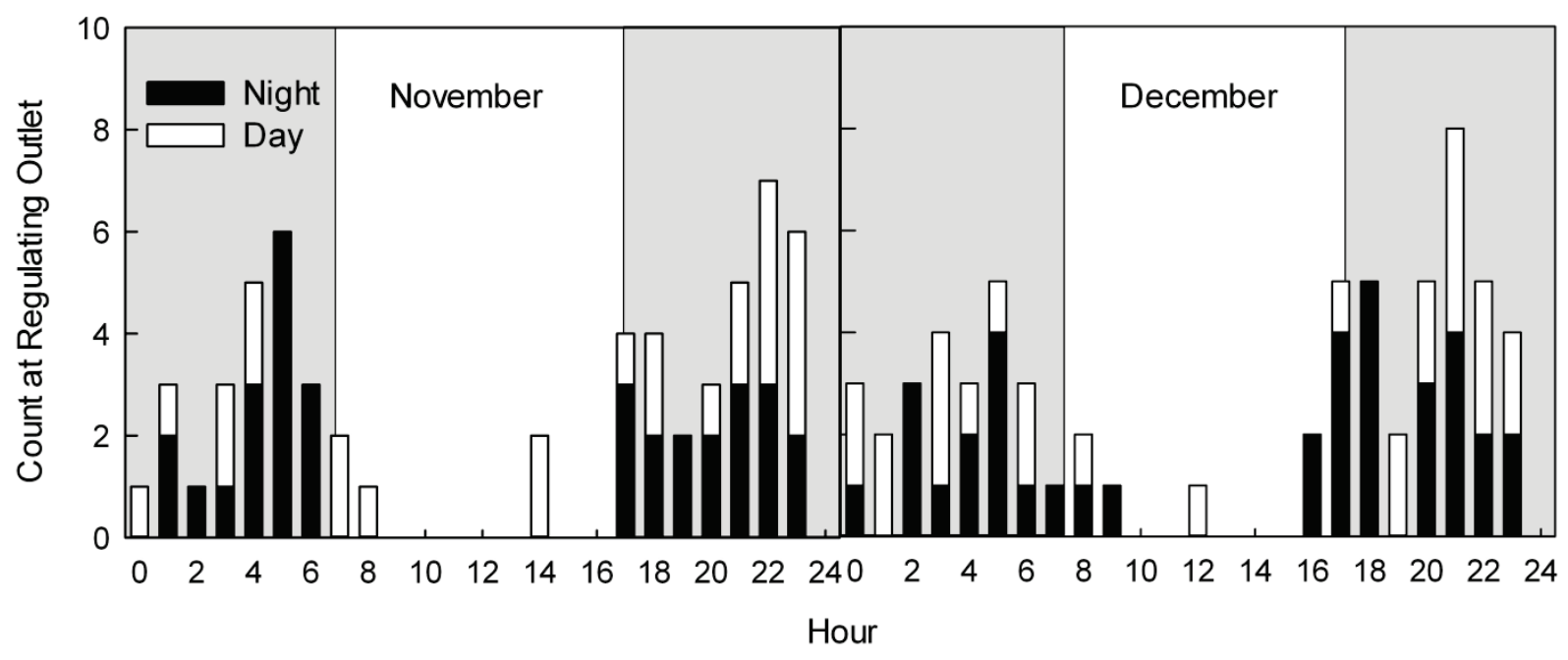

Figure 7. Graph showing hour of known dam passage of radio-tagged juvenile Chinook salmon released in Cougar Reservoir, Oregon, November and December 2012. Bar shading indicates diel period at release. Background shading indicates diel period of dam passage, with the period between the average sunset and sunrise times over the dates of passage shaded. 
Table 2. Summary of dam passage percentages of radio-tagged juvenile Chinook salmon released into the reservoir and into the temperature control tower at Cougar Dam, Oregon, November and December 2012.

[Results are divided by study period, release site and time of release. $N$ is the number of fish released]

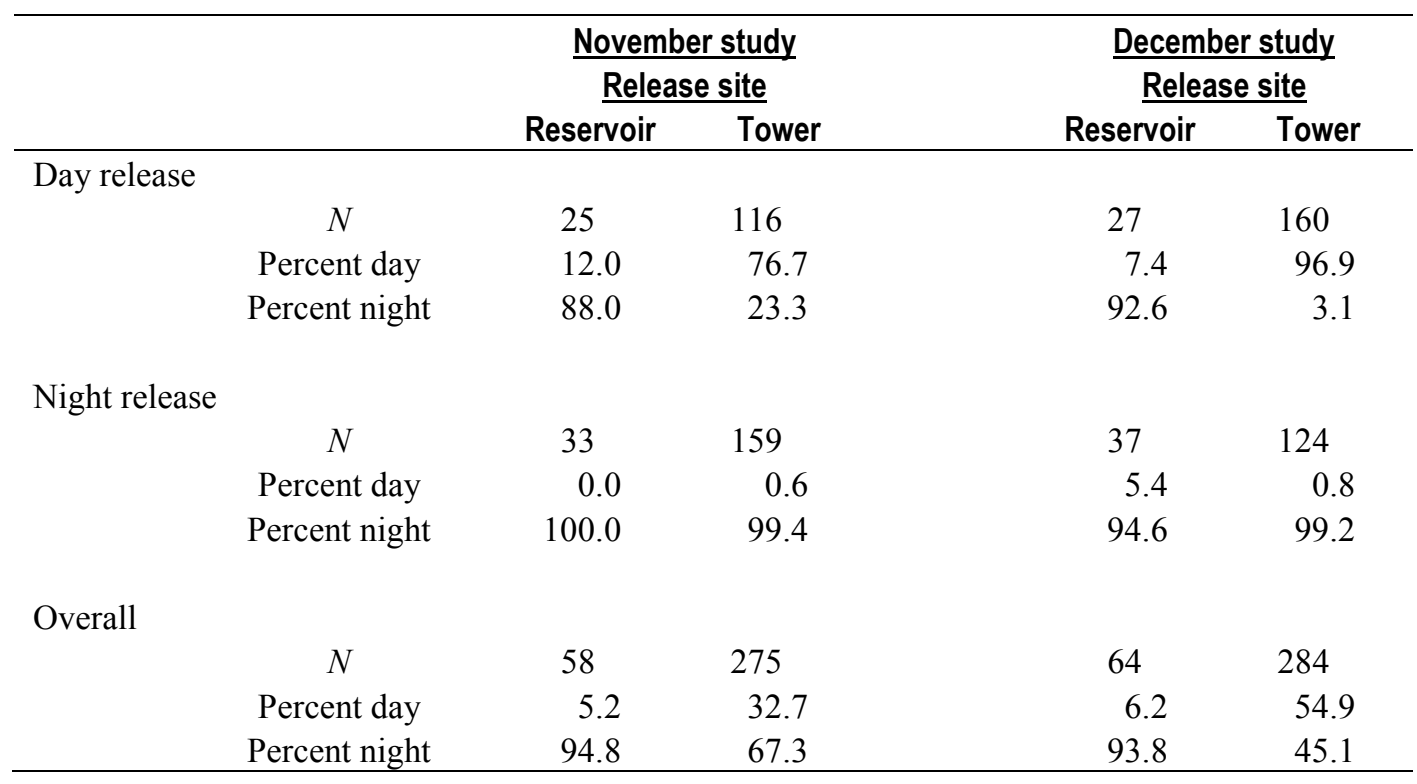

Date of passage

Date of passage
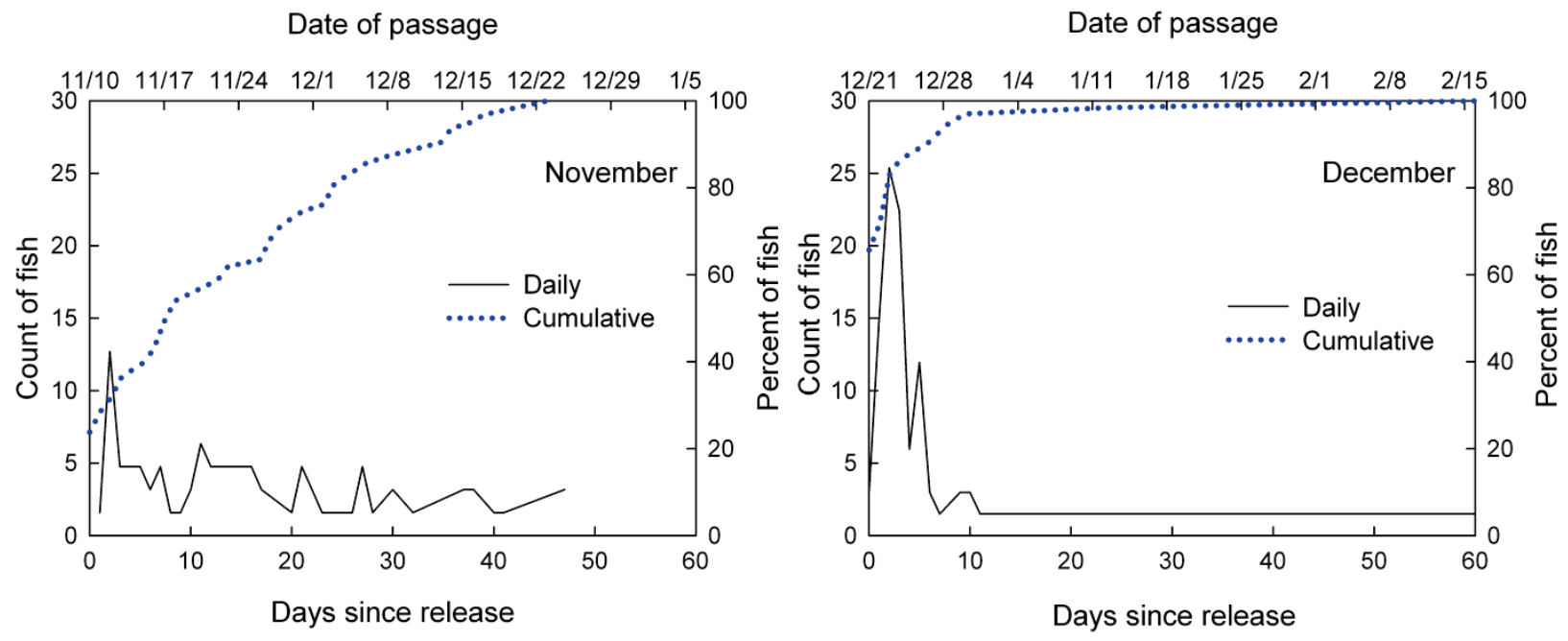

Figure 8. Graphs showing dam passage timing of radio-tagged juvenile Chinook salmon released into Cougar Reservoir, Oregon, during the November and December 2012 study periods. 
The dam passage timing of fish released directly in front of the temperature control tower (the treatment group) varied with time of release (table 2). Fish released during the day passed primarily during the day and those release at night passed primarily during the night.

\section{Travel Times}

Travel times through the study area varied by release site and study period. There was evidence that the travel times differed among the reservoir, control, and treatment groups during both studies (fig. 9). The travel times were shortest during the November study.
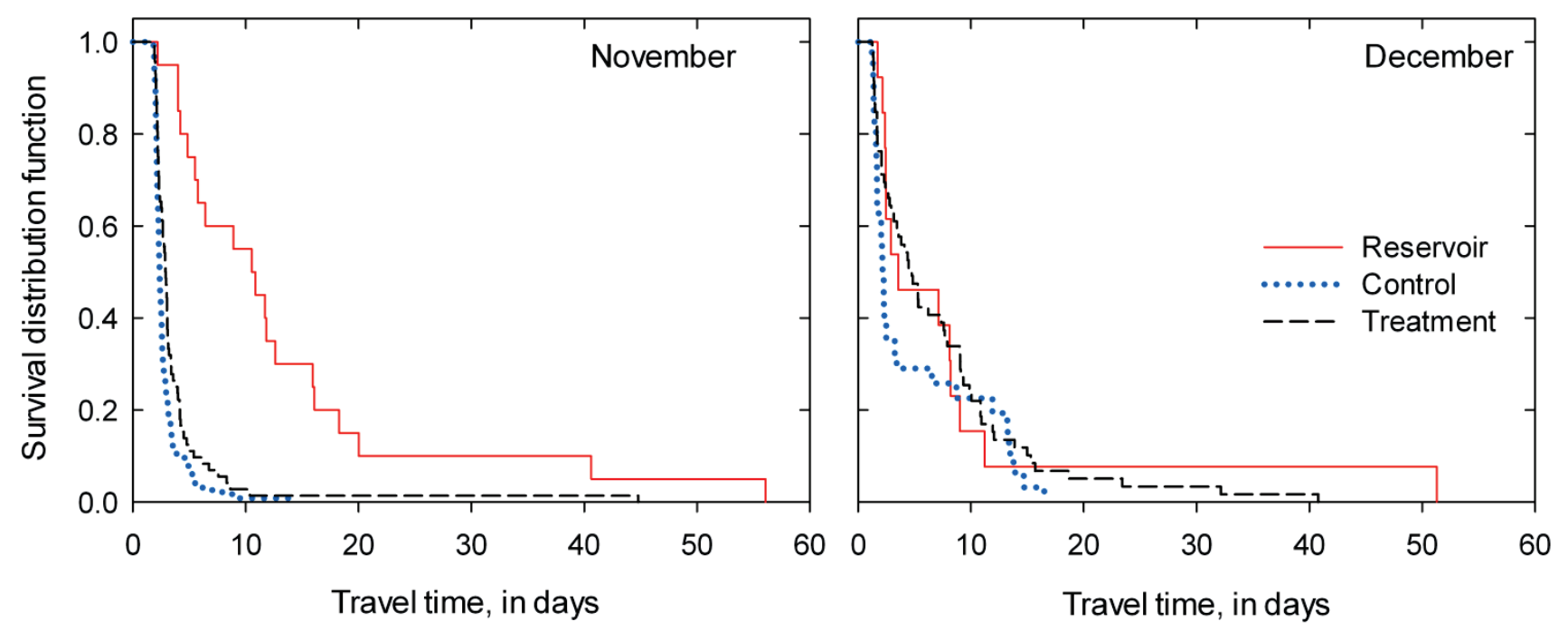

Figure 9. Graphs showing travel time distributions of the three release groups from release to first detection at the Hops Farm site. Survival distribution functions are based on sample sizes at the Hops Farm site of 20, 72, and 114 for the reservoir, treatment, and control groups, respectively, for the November study and 13, 31, and 59 for the reservoir, treatment, and control groups, respectively, for the December study.

During the November study, the travel times from release to the Hops Farm site ranged from 1.88 to 56.06 days, with medians of $2.35,2.89$, and 10.69 days for the control, treatment, and reservoir groups, respectively. The 90th percentile was 4.22 days for the control group, 5.40 days for the treatment group, and 20.02 days for the reservoir group. There were significant differences in the travel time distributions of the three groups (Wilcoxon test, $\mathrm{df}=2, \chi^{2}=39.25, P<0.0001$ ). That result was likely influenced by the long travel times of the reservoir group, so an additional comparison was done with only the control and treatment groups. The results of that comparison indicate that the travel time distributions of the control and treatment groups were significantly different (Wilcoxon test, $\mathrm{df}=2$, $\left.\chi^{2}=9.57, P=0.0020\right)$. The median travel time of fish in the treatment group from the Cougar Dam tailrace to the Leaburg Dam tailrace was 0.46 days and the median travel time of the control group from release to the Leaburg Dam tailrace was 0.36 days. 
There was evidence of a statistical difference among the travel time distributions of the three groups during the December study at the $\alpha=0.10$ level, but not at the $\alpha=0.05$ level (Wilcoxon test, $\mathrm{df}=2$, $\chi^{2}=4.94, P=0.0847$ ). The results comparing the travel time distributions of only the control and treatment groups were similar to those with all three groups (Wilcoxon test, $\mathrm{df}=2, \chi^{2}=3.74, P=0.0530$ ). The travel times through the study area ranged from 1.22 to 51.28 days with medians of 2.17 days for the control group, 4.76 days for the treatment group, and 3.56 days for the reservoir group. The 90th percentile was 13.48 days for the control group, 15.30 days for the treatment group, and 11.23 days for the reservoir group. The median travel time of the treatment group from the Cougar Dam tailrace to the Leaburg Dam tailrace was 0.55 days and the median travel time of the control group from release to the Leaburg Dam tailrace was 0.42 days.

As of December 2, 2013, a total of 140 study fish comprised of 88 fish from the November study and 16 fish from the December study were detected at PIT detectors at either the Cougar Dam tailraces, Leaburg Dam, Walterville Canal (McKenzie River $17 \mathrm{~km}$ downstream of Leaburg Dam), or the Sullivan plant at Willamette Falls (Willamette River $43 \mathrm{~km}$ upstream of the confluence of the Columbia and Willamette Rivers). All but three of the fish detected at PIT detectors were detected within the empirically determined life of the acoustic transmitter. Two of the exceptions were detected at the Walterville site, and one was detected at the Willamette Falls site. The two exceptions detected at the Walterville site included one fish released in the tailrace on November 10,2012, at 7:37 p.m. and detected at the Walterville site on April 18, 2013, at 11:07 a.m., and one released at the temperature control tower on December 22, 2012, at 11:14 a.m. and detected at the Walterville site on April 4, 2013, at 10:57 p.m. The former fish was not detected at any radio telemetry sites and the latter was last detected at a radio telemetry site in the Cougar Dam RO tailrace on December 22, 2012, at 5:05 p.m. The exception detected at the Willamette Falls site was detected there on March 9, 2013, at 5:30 p.m. and was last detected at a radio telemetry site at the Hops Farm on December 29, 2012, at 1:25 p.m.

\section{Estimates of Passage, Detection, and Survival Probabilities}

\section{Assessment of Survival Model Assumptions}

\section{Assumption 2}

Assumption 2 was evaluated by examining the estimates of survival for differences between taggers. The results from each study period were similar - there was little evidence to support a meaningful effect of tagger on fish survival. This conclusion is supported by the similarity of the AICc values of models with and without a tagger effects (table 3 ) and the differences in the estimated survivals. Data from the November study supported one of the tagger effect models (model 2) slightly more than the no tagger effect model (model 1), so we compared estimates of the model-averaged survivals of fish tagged by each tagger to incorporate the model-selection uncertainty. The difference in model-averaged reach-specific single-release survivals between taggers ranged from 0.0254 to 0.0544 , which were well within the error of the estimates. The differences in the relative survivals from the model-averaged estimates were a maximum of 0.0008 . Results from the December study were similar to those of the November study. The model of no tagger effect had similar support from the data as the models with tagger effects, so model-averaged results were examined. The model-averaged reachspecific single-release estimates of survival of fish tagged by the two taggers differed by a maximum of 0.0325 . The largest difference between the reach-specific relative survivals from the model-averaged estimates was 0.0003 . Based on these results, we concluded that there was no meaningful effect of tagger on fish survival. 
Table 3. Comparisons of models with and without effects of tagger on estimates of survival of radio-tagged juvenile Chinook salmon released near Cougar Dam, Oregon, November and December 2012.

[In addition to the factors listed, all models include factors of diet group, treatment group, and reach plus their 2-way interactions on survival (phi) and the factor of reach on detection probability (p). '+' indicates an additive effect, “*” indicates a multiplicative effect, AICc is the Akaike Information Criterion adjusted for sample size, No. parm is number of parameters in the model. The estimated overdispersion parameter (c-hat) was near 1.0 for the November and December studies, so no adjustment was applied. The models are based on the log-link function and are ordered by AICc value. The tagger*trt effect in model 4 from the December Study proved to be a spurious effect and was not considered (nc)]

\begin{tabular}{|c|c|c|c|c|c|c|c|}
\hline $\begin{array}{l}\text { Model } \\
\text { number }\end{array}$ & Model description & $\mathrm{AICc}$ & $\begin{array}{l}\text { Delta } \\
\text { AICc }\end{array}$ & $\begin{array}{c}\text { AICc } \\
\text { weights }\end{array}$ & $\begin{array}{c}\text { Model } \\
\text { likelihood }\end{array}$ & $\begin{array}{l}\text { No. } \\
\text { parm }\end{array}$ & Deviance \\
\hline \multicolumn{8}{|c|}{ - November Study - } \\
\hline \multicolumn{2}{|c|}{ Phi(tagger+reach) } & 2597.950 & 0.000 & 0.852 & 1.000 & 21 & 2555.338 \\
\hline \multicolumn{2}{|c|}{ Phi(no tagger effect) } & 2601.853 & 3.903 & 0.121 & 0.142 & 20 & 2561.296 \\
\hline \multicolumn{2}{|r|}{ Phi(tagger*reach) } & 2605.806 & 7.856 & 0.017 & 0.020 & 25 & 2554.942 \\
\hline \multicolumn{2}{|r|}{ Phi(tagger*trt, tagger*reach) } & 2606.706 & 8.755 & 0.011 & 0.013 & 26 & 2553.771 \\
\hline & \multicolumn{6}{|c|}{ December Study --------------------- } \\
\hline $\mathrm{Ph}$ & hi(no tagger effect) & 2570.382 & 0.000 & 0.559 & 1.000 & 20 & 2529.759 \\
\hline $\mathrm{Ph}$ & hi(tagger+reach) & 2571.482 & 1.100 & 0.323 & 0.577 & 21 & 2528.796 \\
\hline $\mathrm{Ph}$ & hi(tagger*reach) & 2573.501 & 3.119 & 0.118 & 0.210 & 25 & 2522.533 \\
\hline $\mathrm{Ph}$ & hi(tagger*trt, tagger*reach) & 2575.507 & 5.124 & $\mathrm{nc}$ & $\mathrm{nc}$ & 26 & 2522.460 \\
\hline
\end{tabular}

\section{Assumption 7}

Assumption 7 was evaluated by releasing tagged euthanized fish to check directly for false positives, and by comparing transmitter lives to fish travel times to estimate the probability of false negatives. One of the 25 euthanized tagged fish released during each study period was detected downstream of the control release site, indicating violation of Assumption 7 due to false positives. During the November study, one fish released on November 6 was detected at the Leaburg Dam spillway site on November 11. During the December study, one fish released on December 20 was detected at the Aufderheide Bridge and McKenzie River sites on December 21. Detection of dead fish with live transmitters biases estimates of survival upward. There was no compelling evidence supporting violation of Assumption 7 based on false negatives due to transmitter lives being too short for the fish travel times through the study area. The lowest estimated probability of a transmitter being functional at the longest fish travel time was 0.9993 (appendix E). 
To mitigate the violation of Assumption 7 resulting from false positives, the estimates of survival were adjusted using methods described in Skalski and others (2013b). The adjustment accounts for the probability of false positives from detecting dead fish with live transmitters, and reduces the estimated survival accordingly. To enable the adjustment to the data from the November study, the Aufderheide Bridge and McKenzie River sites were omitted from analysis and the adjustment was made to the estimated survival of control and treatment groups between release and Leaburg Dam. For the adjustment to the December data, the Aufderheide Bridge site was omitted and the adjustment was made to the estimated survival of control and treatment groups between release and the McKenzie River site.

\section{Assumption 9}

Assumption 9 was evaluated by comparing reach-specific travel times and site-specific arrival dates of treatment and control groups, and by examining estimates of reach-specific relative survival. There were statistically significant differences in travel time distributions of treatment and control groups in three of the four reach-specific comparisons from the November study, but the groups traveled through the study reaches during similar time periods. In each case, the travel times of the treatment group were longer than those of the control group (table 4), and in most cases the greatest differences occurred late in the distributions (fig. 10). The differences in median travel times ranged from 0.01 days through the $3.2 \mathrm{~km}$ Aufderheide Bridge-to-McKenzie River reach to 0.28 days through the $106.8 \mathrm{~km}$ Marshall Island-to-Hops Farm reach. There also was a significant difference in travel times from Aufderheide Bridge-to-Leaburg Dam, although the median travel times differed by only 0.05 days. Despite the statistical differences in travel times, the treatment and control groups were well mixed temporally as they passed the detection sites downstream of the control release site, and likely experienced similar mortality pressures in those areas (fig. 11). The fish released in the reservoir passed the sites later than the treatment and control groups due to the additional time between release and dam passage, but the reservoir fish were used only used to estimate DPE and passage timing at Cougar Dam.

Table 4. Results of Wilcoxon tests comparing distributions of travel times (days) of treatment and control groups of fish released near Cougar Dam, Oregon, November 6-10, 2012.

[ $N$ denotes the sample size of fish used in the comparison. $>$ is greater than. $\chi^{2}$ is Chi square. $P$ is probability. The numerator degrees of freedom was 1 in each comparison]

\begin{tabular}{|c|c|c|c|c|c|c|c|c|}
\hline \multirow[b]{2}{*}{ Reach } & \multicolumn{3}{|c|}{ Treatment } & \multicolumn{3}{|c|}{ Control } & \multirow[b]{2}{*}{$\mathrm{x}^{2}$} & \multirow[b]{2}{*}{$P>X^{2}$} \\
\hline & $N$ & Median & Range & $N$ & Median & Range & & \\
\hline Aufderheide B. to McKenzie R. & 114 & 0.04 & $0.02-8.14$ & 131 & 0.03 & $0.03-1.50$ & 2.88 & 0.0895 \\
\hline McKenzie River to Leaburg Dam & 86 & 0.28 & $0.22-2.76$ & 114 & 0.25 & $0.20-1.23$ & 18.58 & $<0.0001$ \\
\hline Leaburg Dam to Marshall Island & 83 & 0.93 & $0.46-59.6$ & 99 & 0.90 & $0.41-6.33$ & 1.77 & 0.1838 \\
\hline Marshall Island to Hops Farm & 58 & 1.20 & $0.82-3.15$ & 92 & 0.92 & $0.81-12.93$ & 6.42 & 0.0113 \\
\hline Aufderheide B. to Leaburg Dam & 123 & 0.34 & $0.03-4.94$ & 149 & 0.29 & $0.03-11.48$ & 26.97 & $<0.0001$ \\
\hline
\end{tabular}



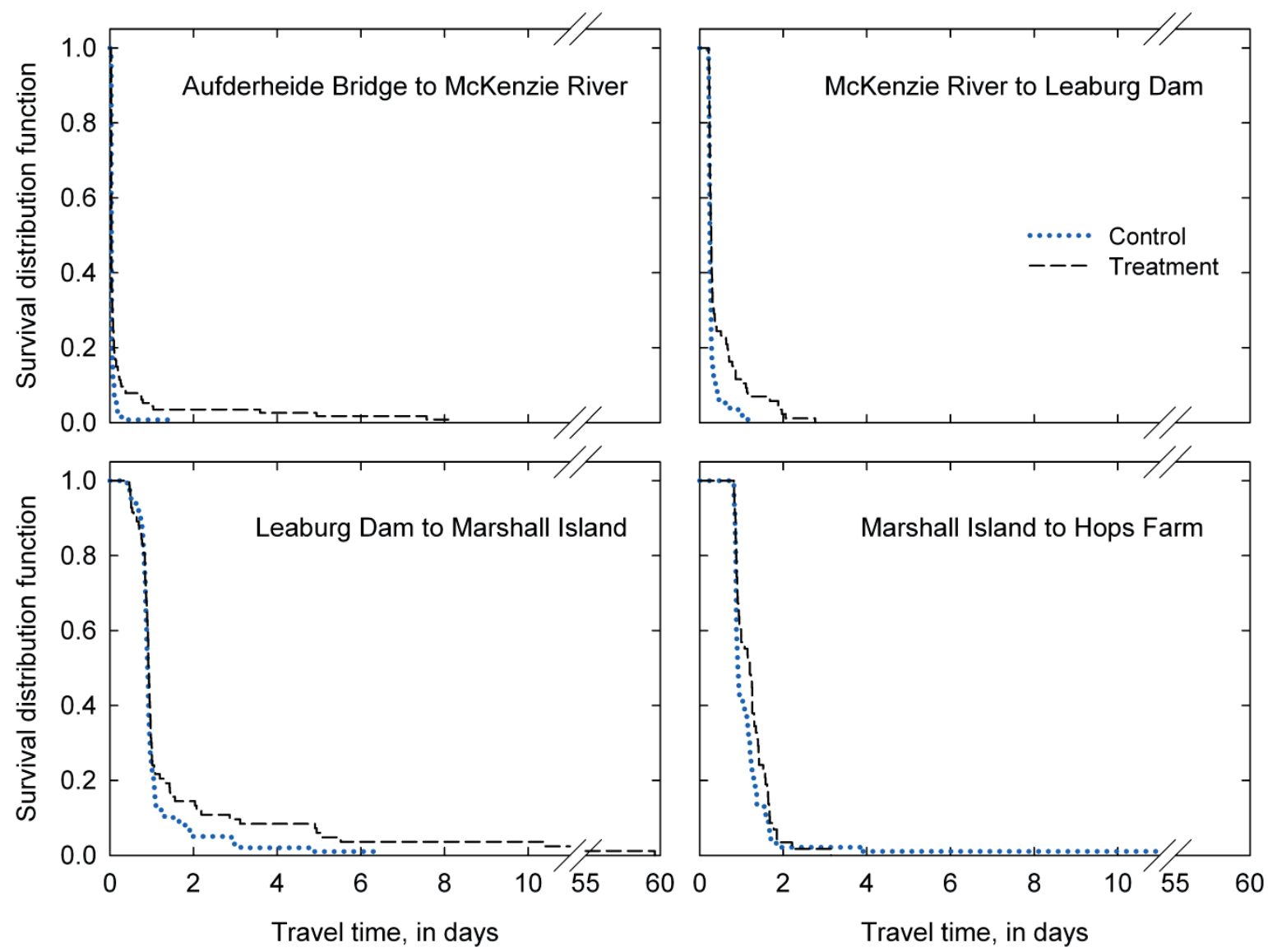

Figure 10. Graphs showing travel time distributions of control and treatment groups of radio-tagged juvenile Chinook salmon released near Cougar Dam, Oregon, November 6-10, 2012. 

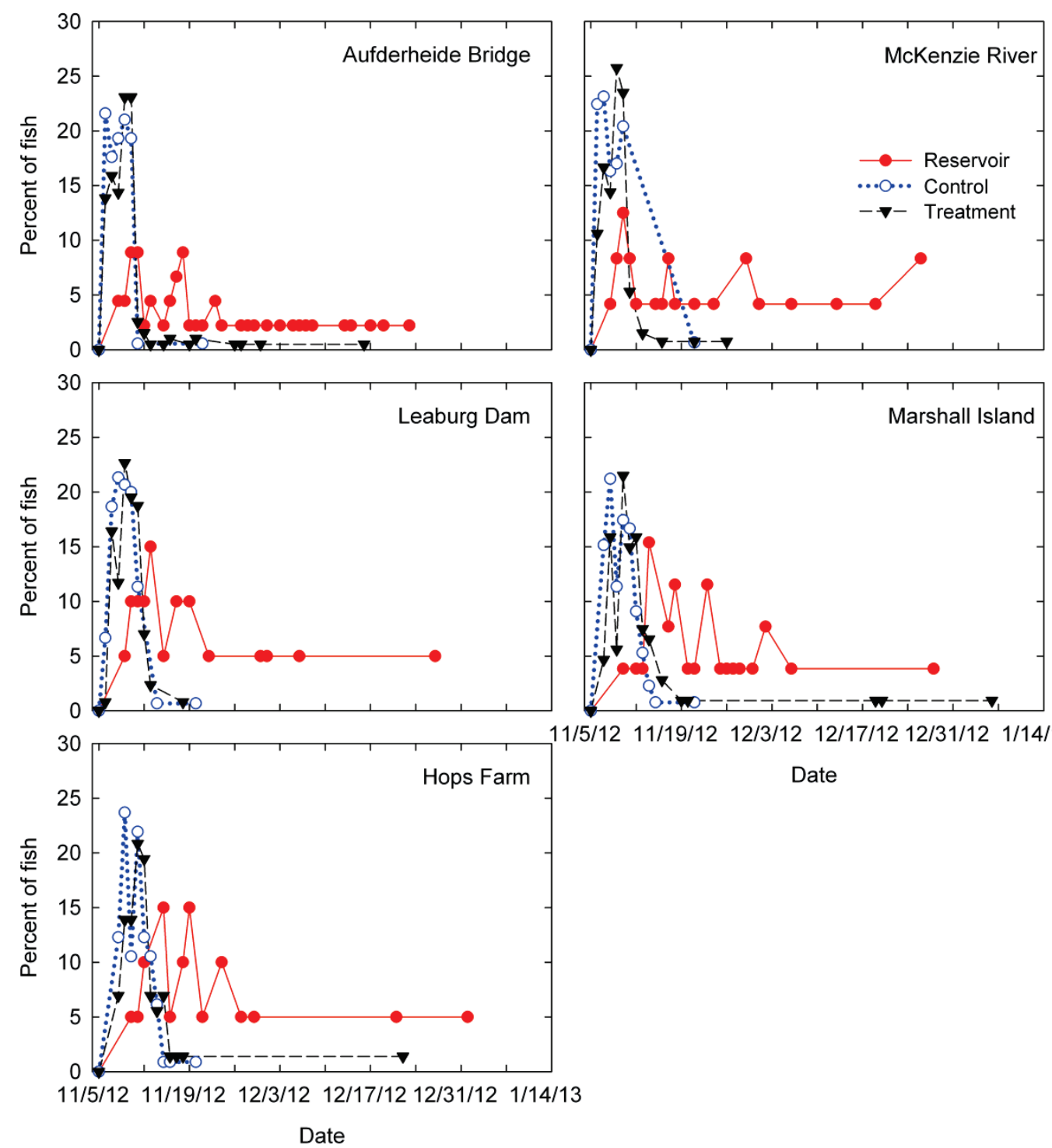

Date

Figure 11. Graphs showing site-specific daily passage percentages of radio-tagged juvenile Chinook salmon released near Cougar Dam, Oregon, November 6-10, 2012. 
As in the November study, during the December study there were statistically significant differences in travel time distributions of treatment and control groups in some reaches, but the groups traveled through the study reaches during similar time periods. The travel times of the treatment group were significantly longer than those of the control group in two of the four reaches (table 5), with the greatest differences occurring late in the distributions (fig. 12). The differences in median travel times were 0.05 days in the $3.2 \mathrm{~km}$ Aufderheide Bridge-to-McKenzie River reach and 1.47 days in the 106.8 $\mathrm{km}$ Marshall Island-to-Hops Farm reach. There also was a significant difference in travel times from Aufderheide Bridge-to-Leaburg Dam, although the median travel times differed by only 0.10 days. The treatment and control groups were well mixed temporally as they passed the detection sites downstream of the control release site, and likely experienced similar mortality pressures in those areas (fig. 13). As in the November study, the fish released in the reservoir passed the detections sites later than the other release groups, but were only used to estimate DPE and passage timing at Cougar Dam.

Table 5. Results of Wilcoxon tests comparing distributions of travel times (days) of treatment and control groups of fish released near Cougar Dam, Oregon, December 18-22, 2012.

$\left[N\right.$ denotes the sample size of fish used in the comparison. $>$ is greater than. $\chi^{2}$ is Chi square. $P$ is probability. The numerator degrees of freedom was 1 in each comparison]

\begin{tabular}{|c|c|c|c|c|c|c|c|c|}
\hline \multirow[b]{2}{*}{ Reach } & \multicolumn{3}{|c|}{ Treatment } & \multicolumn{3}{|c|}{ Control } & \multirow[b]{2}{*}{$x^{2}$} & \multirow[b]{2}{*}{$P>x^{2}$} \\
\hline & $N$ & Median & Range & $\mathrm{N}$ & Median & Range & & \\
\hline Aufderheide B. to McKenzie R. & 160 & 0.12 & $0.02-25.95$ & 91 & 0.07 & $0.02-19.12$ & 4.67 & 0.0307 \\
\hline McKenzie River to Leaburg Dam & 86 & 0.23 & $0.18-2.07$ & 60 & 0.24 & $0.16-33.88$ & 0.32 & 0.5717 \\
\hline Leaburg Dam to Marshall Island & 58 & 0.65 & $0.35-18.54$ & 43 & 0.52 & $0.35-40.74$ & 0.21 & 0.6500 \\
\hline Marshall Island to Hops Farm & 41 & 2.29 & $0.60-14.99$ & 22 & 0.82 & $0.60-14.07$ & 3.93 & 0.0474 \\
\hline Aufderheide B. to Leaburg Dam & 137 & 0.42 & $0.02-31.53$ & 85 & 0.32 & $0.03-34.04$ & 6.43 & 0.0112 \\
\hline
\end{tabular}



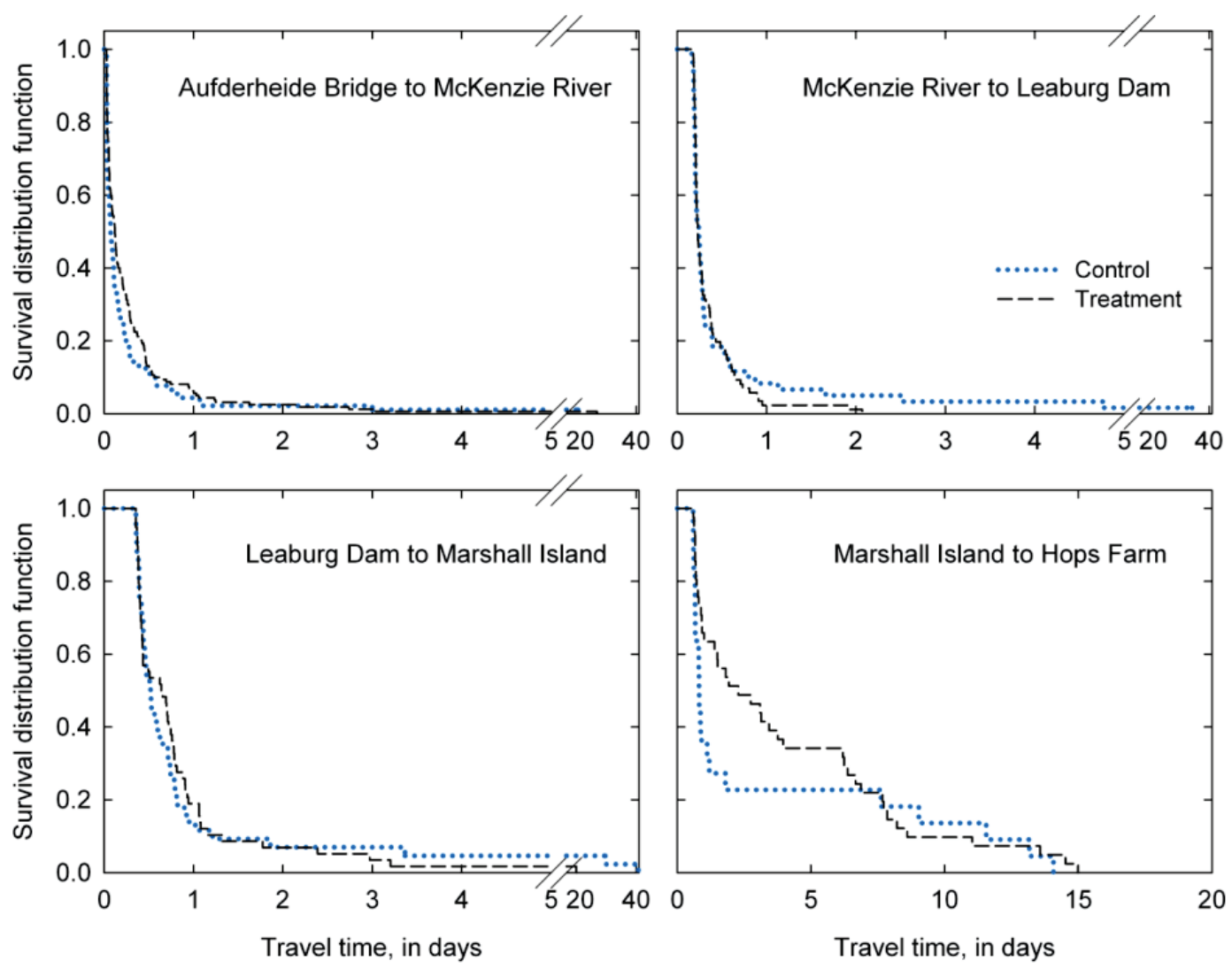

Figure 12. Graphs showing travel time distributions of control and treatment groups of radio-tagged juvenile Chinook salmon released near Cougar Dam, Oregon, December 18-22, 2012. Note that the horizontal-axis scale in the Marshall Island-to-Hops Farm graph differs from the others. 

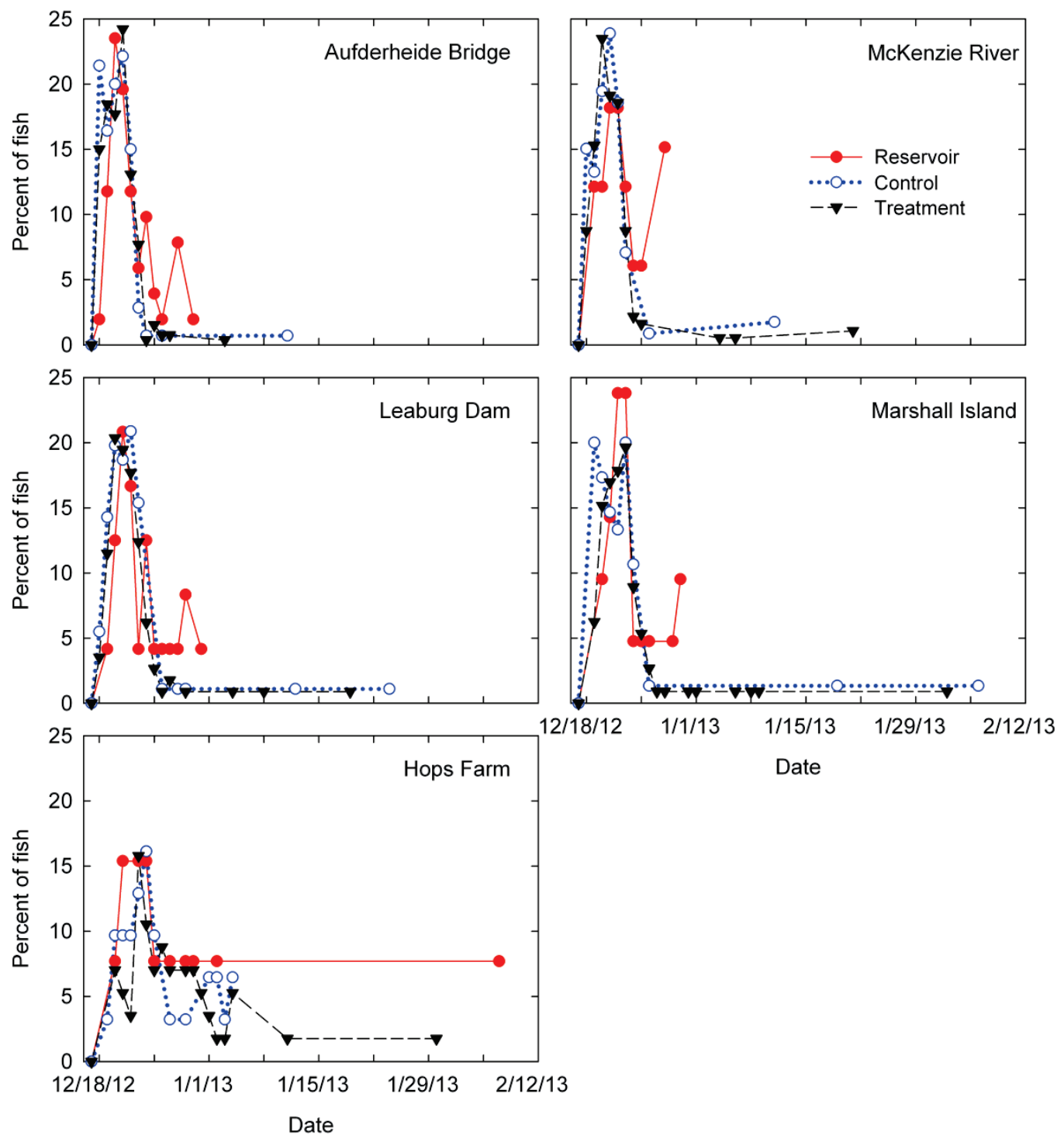

Figure 13. Graphs showing site-specific daily passage percentages of radio-tagged juvenile Chinook salmon released near Cougar Dam, Oregon, December 18-22, 2012.

There was evidence that the mortality associated with dam passage was not fully expressed until the Marshall Island site. The 95-percent confidence intervals of the unadjusted reach-specific relative survivals did not overlap one until the Leaburg Dam-to-Marshall Island reach (fig. 14), indicating Assumption 9 was violated in the reaches upstream. There was much more variability in the estimates for reaches downstream of Leaburg Dam than those upstream of the dam. The median travel time of treatment fish from release to Marshall Island was 1.64 days during the November study and 1.36 days during the December study. We recommend that the assessment of the full mortality associated with Cougar Dam passage during the November and December studies include river reaches to at least the Marshall Island site. 


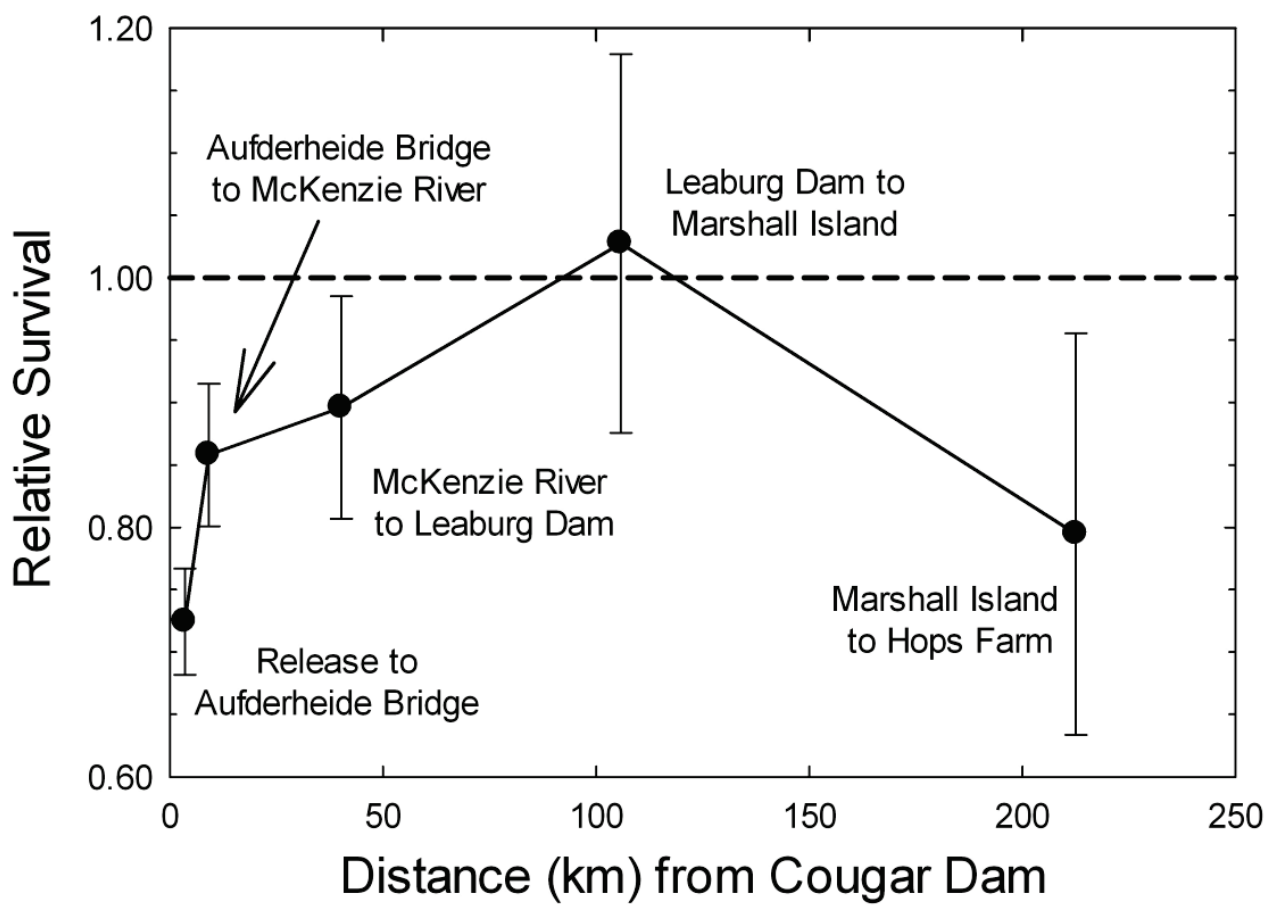

Figure 14. Graphs showing estimates and 95-percent confidence intervals of unadjusted reach-specific relative survival of radio-tagged juvenile Chinook salmon released near Cougar Dam, Oregon, November and December 2012. Confidence intervals spanning the dashed reference line indicate equal survival of treatment and control groups.

\section{Model Selection}

Several models of detection, passage, and survival probabilities were evaluated to determine the most parsimonious means to estimate the parameters. The potential effect of rearing group was evaluated by examining the fish size, travel time, and single-release estimates of survival of treatment and control groups. Based on results from that evaluation, hypotheses about detection, passage, and survival probabilities were evaluated prior to choosing a model from which to estimate the final parameters.

The data from the November and December studies supported models with and without effects of rearing group, and the estimates of survival of fish from the two rearing groups had confidence intervals that overlapped considerably (appendix C). Further inferences were therefore based on data from the rearing groups pooled together.

The reported estimates of passage and survival probabilities were based on simplified models of the parameters (appendix F). The data and models indicated strong support for use of CJS methods to estimate route-specific detection probabilities at the RO and Leaburg Dam spillway, and for fish passing Cougar Dam during the day and night operation periods, so detection probabilities were estimated using that method. The data and models showed moderate support for common spillway and bypass passage probabilities at Leaburg Dam for fish passing Cougar Dam during the day and night operation periods, 
so these were pooled. Lastly, data from fish passing Cougar Dam during the day and night operation periods were pooled to estimate the final survival probabilities based on the similarity in support of models with and without the diel factor and the large overlap of the confidence intervals of survival estimates from the two groups. Site-specific detection probabilities based on the final models ranged from 0.6540 (SE 0.0390) to 0.9862 (SE 0.0141) during the November study, and from 0.5027 (SE 0.0453 ) to 0.9046 (SE 0.0482) during the December study.

\section{Route-Specific Passage Probabilities}

Dam passage of fish in the treatment group during the November study was primarily through the RO and primarily during the night operational period (5:00 p.m.-5:00 a.m.). The treatment group was composed of nearly equal numbers of fish released directly upstream of the temperature control tower during the day and night, and do not represent fish entering the temperature control tower volitionally. The estimated treatment group dam passage probability was 0.893 (SE 0.026) during the November study, indicating that all but about 11 percent of the fish released at the tower passed the dam during the release dates (table 6). Of the treatment fish passing the dam, the estimated probability of dam passage during the day operation was 0.3464 (SE 0.0274), and during the night operation it was 0.6536 (SE 0.0274); that is, about 35 percent of the fish in the treatment group passed during the day operation and the remaining 65 percent passed during the night operation (table 6). The estimated probability of passage through the RO was 0.8842 (SE 0.0294) for treatment fish passing during the day operation and 0.9423 (SE 0.0156) for treatment fish passing during the night operation. The overall RO passage probability when day and night operation periods were pooled was 0.9222 (SE 0.0145).

During the December study, the RO was the only route available and most fish passed during the day operation period. The estimated treatment group dam passage probability was 1.016 (SE 0.027), indicating all or nearly all of the fish passed the dam. Of the treatment fish passing the dam, the diel passage probability estimates were 0.6216 (SE 0.0301) during the day operation, and 0.3784 (SE 0.0301 ) during the night operation (table 6).

The route-specific passage probabilities and the detection probability of the PIT detection system within the fish bypass at Leaburg Dam also were estimated. Most tagged fish passed Leaburg Dam through the spillway. During the November study, the estimate of spillway passage probability was 0.8210 (SE 0.0206), and during the December study, it was 0.9435 (SE 0.0122). The bypass passage probability is estimated as ( 1 minus the spillway passage probability) and was 0.1790 (SE 0.0206) during the November study and 0.0565 (SE 0.0122) during the December study. The estimate of the detection probability of the PIT detection system within the fish bypass was 0.9557 (SE 0.0432) during the November study, and 1.0 (all fish detected) during the December study. 
Table 6. Estimates of route-specific passage probabilities of radio-tagged juvenile Chinook salmon released at Cougar Dam, Oregon, November and December 2012.

[The results are based on fish released at the temperature control tower. PH is powerhouse, RO is regulating outlet, Overall is $\mathrm{PH}$ and RO pooled. The powerhouse did not operate on the passage dates of the treatment fish during the December study. Day and night dam passage periods refer to the operational periods of 5:00 a.m.-5:00 p.m. (day) and 5:00 p.m.-5:00 a.m. (night)]

\begin{tabular}{|c|c|c|c|c|c|}
\hline \multirow{2}{*}{$\begin{array}{l}\text { Dam } \\
\text { passage } \\
\text { period }\end{array}$} & \multirow[b]{2}{*}{ Route } & \multirow[b]{2}{*}{ Estimate } & \multirow{2}{*}{$\begin{array}{c}\text { Standard } \\
\text { error }\end{array}$} & \multicolumn{2}{|c|}{ 95-percent confidence interval } \\
\hline & & & & lower & upper \\
\hline Day & RO & $\begin{array}{l}----- \text { Nov } \\
0.8842\end{array}$ & 0.0294 & 0.8265 & 0.9418 \\
\hline Night & $\begin{array}{l}\mathrm{PH} \\
\mathrm{RO} \\
\mathrm{PH}\end{array}$ & $\begin{array}{l}0.1158 \\
0.9423 \\
0.0577\end{array}$ & $\begin{array}{l}0.0294 \\
0.0156 \\
0.0156\end{array}$ & $\begin{array}{l}0.0582 \\
0.9116 \\
0.0271\end{array}$ & $\begin{array}{l}0.1735 \\
0.9729 \\
0.0884\end{array}$ \\
\hline $\begin{array}{c}\text { Day } \\
\text { Night }\end{array}$ & $\begin{array}{l}\text { Overall } \\
\text { Overall }\end{array}$ & $\begin{array}{l}0.3464 \\
0.6536\end{array}$ & $\begin{array}{l}0.0274 \\
0.0274\end{array}$ & $\begin{array}{l}0.2927 \\
0.5999\end{array}$ & $\begin{array}{l}0.4001 \\
0.7073\end{array}$ \\
\hline Overall & $\begin{array}{l}\mathrm{RO} \\
\mathrm{PH}\end{array}$ & $\begin{array}{l}0.9222 \\
0.0778\end{array}$ & $\begin{array}{l}0.0145 \\
0.0145\end{array}$ & $\begin{array}{l}0.8937 \\
0.0494\end{array}$ & $\begin{array}{l}0.9506 \\
0.1063\end{array}$ \\
\hline $\begin{array}{c}\text { Day } \\
\text { Night }\end{array}$ & $\begin{array}{l}\text { RO } \\
\text { RO }\end{array}$ & $\begin{array}{l}0.6216 \\
0.3784\end{array}$ & $\begin{array}{l}0.0301 \\
0.0301\end{array}$ & $\begin{array}{l}0.5626 \\
0.3193\end{array}$ & $\begin{array}{l}0.6807 \\
0.4374 \\
\end{array}$ \\
\hline
\end{tabular}

\section{Single-Release Survival Probabilities}

The estimated single-release reach-specific survivals of the control group generally were greater than those of the treatment group, as expected. Trends in the single-release estimates of survival from which the relative survival probabilities were calculated generally were as expected. During the November study, the single-release estimates of survival of the control group were higher than those of the treatment group in each reach, but their 95-percent confidence intervals overlapped to a greater degree with distance from Cougar Dam. The single-release estimate of survival of the control group in the November study from release in the Cougar Dam tailrace to Leaburg Dam was 0.9655 (SE 0.0262), indicating a high survival through that reach (appendix $G$ ). The estimate from the treatment group from release at the temperature control tower to Leaburg Dam was 0.4716 (SE 0.0469). The point estimates of single-release survival for the control group from the December study were higher than those for the treatment group in reaches upstream of Leaburg Dam, but they were lower than the treatment group in reaches downstream of Leaburg Dam (appendix G). As in the November study, the amount of overlap of their 95-percent confidence intervals increased with distance from Cougar Dam. The jointprobabilities of the single-release estimates for the survival from release to Leaburg Dam during the December study were 0.8781 (SE 0.0614) for the control group and 0.5588 (SE 0.0464) for the treatment group.

The control group single-release survival estimates from the December study were lower than those from the November study, suggesting the in-river survival conditions differed between studies (appendix G). For example, the reach-specific estimate of control group survival in the Marshall Islandto-Hops Farm reach was 0.7239 (SE 0.0420) in the November study, and 0.3643 (SE 0.0816) during the December study. 
The single-release survival estimates of the control groups also may be expressed as the survival per $100 \mathrm{~km}$ for comparison with other studies. The estimated survivals of the control group per $100 \mathrm{~km}$ during the November study were 0.7900 (SE 0.1341), 0.8041 (SE 0.0366), and 0.7390 (SE 0.0401) for the release-to-McKenzie River, McKenzie River-to-Marshall Island, and Marshall Island-to-Hops Farm reaches, respectively. The estimates from the December study were 0.6431 (SE 0.2644), 0.5942 (SE 0.0733), and 0.3884 (SE 0.0815) for release-to-McKenzie River, McKenzie River-to-Marshall Island, and Marshall Island-to-Hops Farm reaches, respectively. The three reaches represent migration primarily through the South Fork of the McKenzie River, the McKenzie River, and the Willamette River, respectively. The point estimates from the December study are lower than those from the November study, but the 95-percent confidence intervals (estimated as \pm 1.96 times the SE) of the reach-specific estimates overlap in all but the Marshall Island-to-Hops Farm reach.

\section{Relative Survival Probabilities}

Adjusting estimates of survival for the probability of false positives due to detecting euthanized fish with live radio transmitters lowered the estimates of relative survival for the pooled reaches by about 0.02 from the unadjusted results. The minimum reaches over which adjusted survival could be estimated was release-to-Leaburg Dam for the November study and release-to-McKenzie River for the December study. However, the reach-specific paired release estimates of survival suggested the treatment effect was not expressed until the Leaburg Dam-to-Marshall Island reach.

The estimated relative survival of RO passage was lower during the November study than during the December study. The relative survival of dam passage between release and Marshall Island was 0.4594 (SE 0.0543) during the November study and 0.7389 (SE 0.1160) during the December study (table 7). The temperature control tower-to-Marshall Island relative survival during the December study was higher than the temperature control tower-to-Leaburg Dam estimate, because the estimate of relative survival from Leaburg Dam to Marshall Island was greater than 1.0. Estimates greater than 1.0 can arise normally due to variation in estimated survivals of treatment and control groups. In this case, the point estimate of survival for the control group was low relative to the treatment group ( 0.6680 versus 0.7699 ; appendix $\mathrm{G}$ ) resulting in a relative survival of 1.1612 . The confidence intervals about the estimates overlapped considerably (control 0.4966-0.8305, treatment 0.6172-0.9226), suggesting the estimates were similar. In general, the estimates for the reaches downstream of Leaburg Dam were imprecise compared to those upstream of the dam. 
Table 7. Estimates of relative reach-specific survival probabilities of radio-tagged juvenile Chinook salmon passing through the regulating outlet at Cougar Dam, Oregon, November and December 2012.

[Results are based on the estimated survival of fish released at the temperature control tower (treatment group) divided by the estimated survival of fish released in the tailrace (control group) after adjustment for detection of euthanized fish with live transmitters]

\begin{tabular}{|c|c|c|c|c|}
\hline \multirow[b]{2}{*}{ Reach } & \multirow[b]{2}{*}{ Estimate } & \multirow{2}{*}{$\begin{array}{l}\text { Standard } \\
\text { error }\end{array}$} & \multicolumn{2}{|c|}{ 95-percent confidence interva } \\
\hline & & & lower & upper \\
\hline & ber Study - & & & \\
\hline Temperature control tower to Leaburg Dam & 0.4885 & 0.0497 & 0.3910 & 0.5860 \\
\hline Temperature control tower to Marshall Island ${ }^{1}$ & 0.4594 & 0.0543 & 0.3530 & 0.5659 \\
\hline Marshall Island to Hops Farm & 0.7675 & 0.0821 & 0.6066 & 0.9284 \\
\hline & ber Study & r & & \\
\hline Temperature control tower to McKenzie River & 0.6669 & 0.0496 & 0.5626 & 0.6807 \\
\hline McKenzie River to Leaburg Dam & 0.9543 & 0.0934 & 0.7713 & 1.1373 \\
\hline Leaburg Dam to Marshall Island & 1.1612 & 0.1898 & 0.7891 & 1.5333 \\
\hline Marshall Island to Hops Farm & 1.0396 & 0.2766 & 0.4975 & 1.5817 \\
\hline Temperature control tower to Leaburg Dam & 0.6364 & 0.0682 & 0.5026 & 0.7701 \\
\hline Temperature control tower to Marshall Island ${ }^{1}$ & 0.7389 & 0.1160 & 0.5115 & 0.9664 \\
\hline
\end{tabular}

${ }^{1}$ Minimum reach for expression of treatment effects.

\section{Discussion}

The route-specific passage probabilities were similar to those previously reported for radiotagged fish at Cougar Dam. The probabilities of day and night RO passage from the November study (0.8842 day, 0.9423 night) were nearly identical to those from a similar study in November 2011 (0.8896 day, 0.9417 night; Beeman and others, 2012). When all available data are used together, the resulting spill efficiency fitted curve shows a steep increase in RO fish passage proportion up to an RO discharge passage proportion of about 0.2 , after which it is nearly linear (fig. 15). The predicted relation can be used to estimate the proportion of fish expected to pass through the $\mathrm{RO}$ at various allocations of total discharge between the powerhouse and $\mathrm{RO}$, although data from low proportions of water passing the $\mathrm{RO}$ is lacking. The high efficiency of the RO relative to the penstock is likely because the elevation of the $\mathrm{RO}$ entrance is $60 \mathrm{ft}$ higher than the elevation of the penstock, and volitionally migrating fish pass the $\mathrm{RO}$ entrance prior to the penstock entrance. 


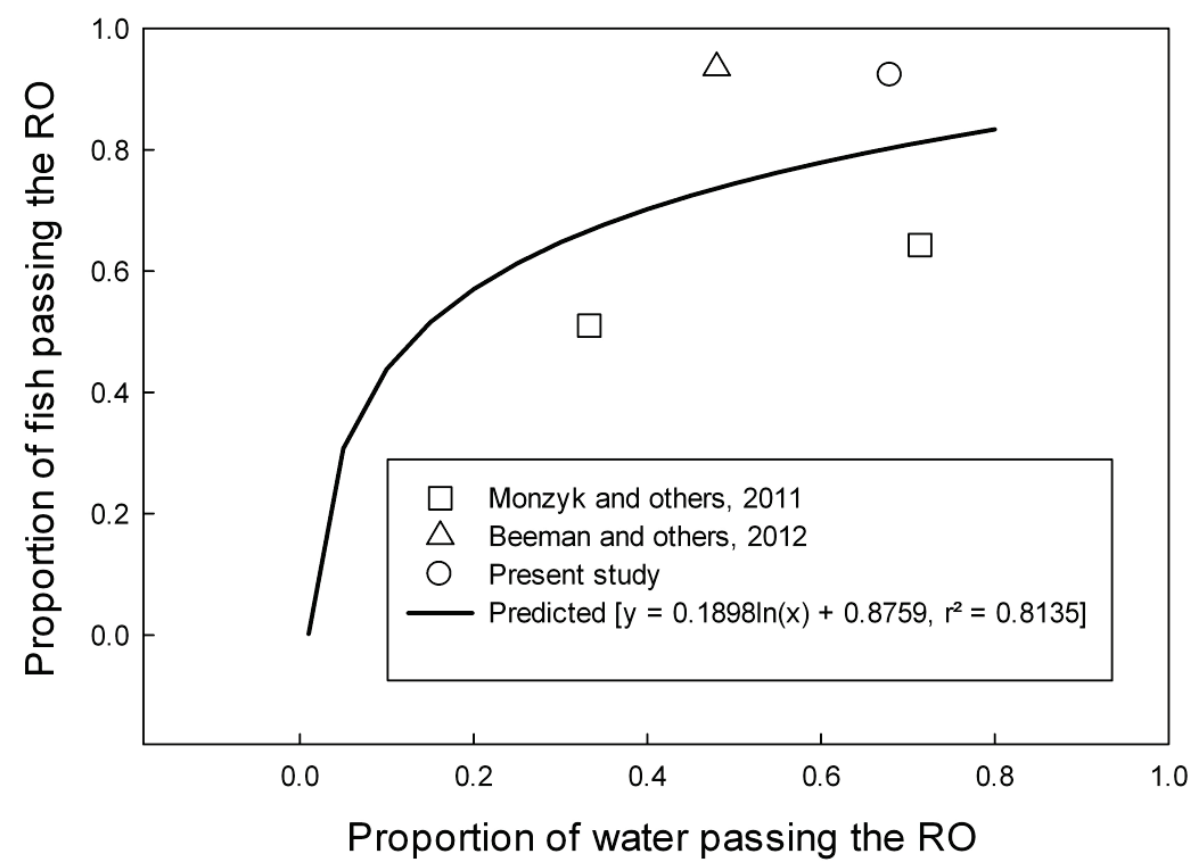

Figure 15. Graph showing regulating outlet (RO) fish passage efficiency curve for juvenile Chinook salmon at Cougar Dam, Oregon, based on the available data. The logarithmic function (solid line) is forced through the $x, y$ pair $0.01,0.01$.

Most tagged fish released in the reservoir passed at night, which is consistent with results of other studies. The percentage of these fish passing the dam at night was 94.8 during the November study, and 93.8 during the December study. Beeman and others (2013) estimated that 92.7 percent of volitionally migrating acoustic-tagged fish passed Cougar Dam at night; the tagged fish in that study had been in Cougar Reservoir for weeks, and were presumed to be depth-acclimated. Volitional passage at dams is often greater at night than during the day (Bregge and others, 1996). If future fish passage actions at Cougar Dam include a device to collect fish from nearer to the water surface the predominance of night passage may change, because night passage can be less pronounced at routes with shallow entrances like spillway weirs compared to deep entrances like turbines (Beeman and others, 2010; Ploskey and others, 2013).

The DPE of volitionally passing fish was similar during the November and December studies, but their dam passage was much quicker during the December study. About 70 percent of the fish released in the reservoir passed the dam during each study. This is similar to the estimated DPE of fish implanted with acoustic transmitters for a concurrent study we conducted, which was 69.8 percent $(226$ of 324 fish) during the passage dates of the fish released in the reservoir during the November study (unpub. data; there were too few fish from that study to estimate DPE during the December study period). The time from release to passage during the November study (median 9.3 days) was much longer than during the December study (median 1.0 day), indicating the dam operating conditions were more conducive to fish passage during the December study. The fate of the fish that did not pass is unknown; they may have died before passing the dam, lived but never passed the dam during the study periods, or passed the dam without detection at any downstream sites. It is possible that at release some 
fish migrated upstream instead of downstream and were never at risk of passing the dam — this would explain the similarity in DPE and difference in passage timing between the study periods.

The survival model assumptions were either satisfied or adjusted for during each study period. There was little evidence of an effect of tagger skill or premature failure of radio transmitters on survival estimates. There were statistically significant differences in travel times between treatment and control groups through several of the reaches they had in common, but the differences were typically of a few hours and were likely not biologically meaningful. Fish of each group were likely exposed to the same mortality pressures in the reaches they had in common. There was direct evidence of false positive detections at some sites, as indicated by detection of 1 of 25 euthanized tagged fish released in each study period. This did not occur during a similar study during November 2011, but the dam discharge was much lower then (Beeman and others, 2012). The effects of this assumption violation were ameliorated by adjusting the survival estimates for the probability of detecting euthanized tagged fish. This required fewer detection sites to be omitted (1-2 sites) from analysis than an alternative method, which requires omission of all sites with detections of euthanized fish (2-3 sites). The adjusted relative survival probabilities were about 0.02 lower than the original estimates, but the violation precluded unbiased survival estimates in reaches upstream of Leaburg Dam for the November study and the McKenzie River site for the December study.

The effects of passage at Cougar Dam were not fully expressed until the Leaburg Dam-toMarshall Island reach. A delay in expression of passage mortality is consistent with results based on balloon-tagged fish reported by Normandeau and Associates, Inc. (2010), given the differences in their estimated survivals 1- and 48-hours post passage, and the fast migration rates of the fish in our studies. The median travel time of the treatment group from release to the Marshall Island site $105.8 \mathrm{~km}$ downstream of the Cougar Dam was 1.64 days during the November study and 1.36 days during the December study, reflecting median travel rates of $64.5 \mathrm{~km} / \mathrm{d}$ and $77.8 \mathrm{~km} / \mathrm{d}$. The median travel times from the Cougar Dam tailrace to the Hops Farm site $212.6 \mathrm{~km}$ downstream was 2.89 days in the November study and 4.76 days in the December study and the fastest fish traveled at an average rate of more than $100 \mathrm{~km} / \mathrm{d}$. We cannot discern from the data exactly where the effects were fully expressed, only that it was between Leaburg Dam and the Marshall Island site. Due to the fast travel rates of the fish, we recommend that future active telemetry studies of dam passage survival at sites like Cougar Dam maintain detection sites well downstream to enable the effects of dam passage to be evaluated over appropriate time frames. It also may be useful to hold fish from future balloon-tag studies at facilities like Cougar Dam for longer than 48 hours after passage to broaden the evaluation period for estimating the time required to fully express treatment effects.

The relative survival of fish passing through the RO was greater during December than during November. The estimate was 0.4594 (95 percent CI $0.3530-0.5659$ ) for the November study and 0.7389 (95 percent CI 0.5115-0.9664) for the December study. The primary differences in the dam operating conditions between the studies were the reservoir elevation, dam discharge, location of the entrance to the temperature control tower, and height of the RO gate openings. During the December study, the reservoir elevation was below the power pool elevation and all discharge passed through the RO through the RO bypass gate rather than through the $\mathrm{RO}$ weir gates. The increased discharge and low pool elevation resulted in much larger RO gate openings than in the November study.

The results of November and December studies indicate that dam passage survival of juvenile Chinook salmon passing through the RO was greater than the estimate from radio-tagged fish during November 2011. The November 2011 study was based on a single-release design to estimate survival and estimated that survival of fish passing through the RO downstream to Leaburg Hatchery (slightly downstream of Leaburg Dam) was 0.1927 (95 percent CI 0.1421-0.2550; Beeman and others, 2012). 
The November 2012 single-release estimate to Leaburg Dam was 0.5176 (95 percent CI 0.4434 0.5918 ), which is 2.7 times greater than the estimate from 2011. The December 2012 single-release estimate to Leaburg Dam was 0.6364 (95 percent CI 0.5026-0.7701), which is 3.3 times greater than the estimate from 2011. The conditions during the two November studies were similar except for the deliberate changes in dam operations as part of the study design and the release pipe diameter $(5.1 \mathrm{~cm}$ in 2011 and $7.62 \mathrm{~cm}$ in 2012). The conditions were much different during the December 2012 study due to the low pool elevation, the use of the RO bypass entrance, and large RO gate opening. The primary differences in the conditions between the two November studies are the total discharge, the allocation of discharge between the powerhouse and RO, and the RO gate opening (table 8). The average total discharge at Cougar Dam in the 2012 study was 2.1 times greater than in the 2011 study, and discharge in the rivers downstream was greater as well. During the 2011 study, the discharge was nearly evenly divided between powerhouse and RO routes, but in the November 2012 study the discharge was primarily through the powerhouse during the day and primarily through the RO at night. The differences in the allocation and magnitudes of the discharge led to differences in the RO gate openings between years with an average of $1.21 \mathrm{ft}$ during the day and $3.18 \mathrm{ft}$ at night in 2012 and $1.25 \mathrm{ft}$ (assumed constant during day and night) in 2011. Previous studies have shown survival and passage conditions to improve with RO gate opening size at Cougar Dam (Duncan, 2011; Monzyk and others, 2011). Thus, the greater RO gate opening during the night in November 2012 may be one reason for the higher survival in 2012 compared to 2011. It also is possible that greater discharge in the rivers downstream provided a survival benefit as fish traveled through the study area after dam passage. The effect of the different release pipes cannot be separated from the other differences between the studies.

The estimates of dam passage survival from the studies based on radio-tagged fish at Cougar Dam have been considerably lower than those of previous studies using balloon tags or PIT tags. The results from balloon-tagged fish released near the $\mathrm{RO}$ gate opening indicated direct relative survival 48 hours post-passage was 84.6-88.3 percent, depending on the study conditions (Normandeau Associates, Inc., 2010; table 8). A study using PIT-tagged fish released in the same manner as the balloon-tagged fish estimated the relative recapture probability to Leaburg Dam, a surrogate for relative survival, was 0.85 (SE 0.06) at the $1.5 \mathrm{ft}$ gate opening and 1.04 (SE 0.09) at the $3.7 \mathrm{ft}$ opening (Monzyk and others, 2011). There are several differences between the studies that can be examined here, including the dam operating and environmental conditions, tagging and handling effects, and the release method.

The mortality measured in the studies using radio transmitters and PIT tags includes both direct and indirect effects, whereas mortality measured in balloon-tag studies includes only direct effects. Direct effects include strike, shear, and barotrauma and indirect effects include increased vulnerability to predation. Estimates of survival accounting for direct and indirect mortality effects are often lower than those with only direct effects (Ferguson and others, 2006). In addition, indirect effects may take longer than direct effects to be fully expressed, given the differences in the mechanisms. Thus, survival estimated from balloon-tagged fish is expected to be higher than those from radio-tagged or PIT-tagged fish. However, the differences between the results of the balloon-tag and radio-tag studies are greater than one would expect unless the indirect mortality was very high, which is not supported by the results from PIT-tagged fish. 
Table 8. Summary of test conditions of studies of passage survival through the regulating outlet at Cougar Dam, Oregon.

[Radio telemetry 2011 data are from Beeman and others (2012), balloon tag data is from Normandeau and Associates, Inc. (2010), and PIT tag data are from Monzyk and others (2011). Numbers other than survival estimates are means. Head is the difference between forebay elevation and passage route centerline elevation.RO is regulating outlet, $\mathrm{ft}^{3} / \mathrm{s}$ is cubic feet per second, $\mathrm{ft}$ is feet, and ${ }^{\circ} \mathrm{C}$ is degrees Celsius. -- indicates not applicable or not reported]

\begin{tabular}{|c|c|c|c|c|c|c|c|c|}
\hline \multirow[b]{4}{*}{ Metric } & \multirow[b]{4}{*}{ Type } & \multicolumn{7}{|c|}{ Study } \\
\hline & & \multicolumn{3}{|c|}{ Radio telemetry } & \multirow{2}{*}{\multicolumn{2}{|c|}{$\begin{array}{c}\text { Balloon tag } \\
2009\end{array}$}} & \multirow{2}{*}{\multicolumn{2}{|c|}{$\begin{array}{c}\text { PIT tag } \\
2009\end{array}$}} \\
\hline & & \multirow{2}{*}{$\begin{array}{c}2011 \\
\text { November }\end{array}$} & \multicolumn{2}{|c|}{2012} & & & & \\
\hline & & & November & December & $\begin{array}{l}1.5 \mathrm{ft} \\
\mathrm{RO}\end{array}$ & $\begin{array}{l}3.7 \mathrm{ft} \\
\mathrm{RO}\end{array}$ & $\begin{array}{l}1.5 \mathrm{ft} \\
\mathrm{RO}\end{array}$ & $\begin{array}{c}3.7 \mathrm{ft} \\
\mathrm{RO}\end{array}$ \\
\hline Total discharge $\left(\mathrm{ft}^{3} / \mathrm{s}\right)$ & Overall & 1,110 & 1,566 & 1,821 & -- & -- & -- & -- \\
\hline \multirow[t]{3}{*}{ RO discharge $\left(\mathrm{ft}^{3} / \mathrm{s}\right)$} & Day & -- & 548 & 1,855 & 440 & 1040 & 440 & 1040 \\
\hline & Night & -- & 1,333 & 1,800 & -- & -- & -- & -- \\
\hline & Overall & 540 & 1,024 & 1,821 & -- & -- & -- & -- \\
\hline \multirow[t]{2}{*}{ RO gate opening ( $\mathrm{ft}$ ) } & Day & 1.25 & 1.21 & 7.34 & 1.5 & 3.7 & 1.51 & 3.7 \\
\hline & Night & 1.25 & 3.18 & 7.55 & -- & -- & -- & -- \\
\hline \multicolumn{9}{|l|}{ Elevation (ft } \\
\hline NGVD29) & & 1,580 & 1,589 & 1,507 & 1,532 & 1,532 & 1,532 & 1,532 \\
\hline Head (ft) & & 91.3 & 100.1 & 18.4 & 43.5 & 43.5 & 43.5 & 43.5 \\
\hline Temperature $\left({ }^{\circ} \mathrm{C}\right)$ & & 7.2 & 6.7 & 5.1 & 10.5 & 10.5 & -- & -- \\
\hline Fork length (mm) & & 132.4 & 148.2 & 160.1 & 172.3 & 172.3 & -- & -- \\
\hline $\begin{array}{l}\text { Single-release } \\
\text { survival (percent) }\end{array}$ & $\begin{array}{l}\text { to Leaburg } \\
\text { Dam }\end{array}$ & 19.3 & 47.2 & 55.9 & -- & -- & -- & -- \\
\hline \multirow[t]{3}{*}{$\begin{array}{l}\text { Relative survival } \\
\text { (percent) }\end{array}$} & $\begin{array}{l}\text { to Leaburg } \\
\text { Dam }\end{array}$ & -- & 51.8 & 63.6 & -- & -- & 85 & 104 \\
\hline & 1 hour & -- & -- & -- & 91.7 & 92.6 & -- & -- \\
\hline & 48 hour & -- & -- & -- & 84.6 & 88.3 & -- & -- \\
\hline
\end{tabular}

Dam operating conditions may affect survival, but many aspects of the conditions during the various studies were similar. In particular, the conditions during the studies of radio-tagged fish conducted in November 2011 and 2012 were similar to those during the December 2009 studies based on balloon tags and PIT tags (table 8). The time of year, discharge, and gate opening at the RO are similar among the studies and the primary dam operating difference between studies was the forebay elevation. The forebay elevation of the balloon tag and PIT tag studies was $1,533 \mathrm{ft}$, whereas the November studies based on radio telemetry were done at mean elevations of 1,580 and 1,586 ft. The elevation differences resulted in a difference in head over the centerline of the RO opening of 47.8-56.6 ft. Passage survival through turbines has been shown to be negatively related to head (hydrostatic pressure) due to barotrauma caused by the difference between acclimation and minimum exposure pressures (Carlson and others, 2012). The minimum exposure pressures during turbine passage are typically at the downstream side of the turbine runner and approach vapor pressure in some cases, depending on turbine design and operating conditions. In contrast to passage through turbines, the conditions during passage through some other routes, such as the RO at Cougar Dam, are not likely to 
result in minimum exposure pressures much different than atmospheric pressure, because they are open to the atmosphere at the downstream end. This premise is supported for the RO at Cougar Dam by results from sensor packages passed through the RO during the balloon tag and PIT tag studies. Duncan (2011) reported that the minimum exposure pressures of sensor packages passed through the RO were about 14 pounds per square inch absolute (psia) and they occurred near the downstream side of the RO gate. Thus, the acclimation and minimum exposure pressures will be very similar and the differences in head among the studies are not likely to result in differences in survival through the RO due to barotrauma.

There are differences in tagging, handling, and release procedures among the three tag types used to study passage survival at Cougar Dam. Radio-tagged fish had the tags surgically implanted under deep anesthesia, were held near the water surface for at least 18 hours to recover from the tagging procedure, and were released through a PVC pipe near the water surface. During the recovery period, the fish can add air to their swim bladder to regain near-neutral buoyancy The surface-acclimated radiotagged fish then passed through the temperature control tower and into the RO volitionally. Balloontagged fish have radio transmitters and balloon tags externally attached under light anesthesia shortly (about 30-45 minutes) prior to release and are passed through flexible hoses to the release point, usually at the desired depth slightly upstream of the route of passage. The balloon-tagged fish were released inside the temperature control tower about $2 \mathrm{ft}$ higher than the centerline of the RO gate opening (Normandeau Associates, Inc., 2010). Balloon-tagged fish are surface-acclimated, may not be neutrally buoyant, and do not pass the route volitionally. The PIT-tagged fish were sedated and tagged an unspecified time prior to release (generally days or weeks beforehand) and were released using the same mechanism used for the balloon-tagged fish (Monzyk and others, 2011). There are several issues that could affect estimates of survival based on differences in the tag and handling procedures among the studies. These include the release mechanism, tag burden, and passage conditions.

The release pipe used in the studies based on radio-tagged and balloon-tagged/PIT-tagged fish were different in size and material. The differences in pipe type and diameter among studies could affect survival, but the single-release survival estimates of control fish during the studies in 2012 were high (release to Leaburg Dam 0.9655 November, 0.8781 December), leaving little room for an effect to be present. The 2011 radio tag study was based on a single-release design, so there were no downstream releases with which to evaluate the question. Based on the available information, we surmise that this source is a plausible, yet unlikely, factor affecting the differences in survival among the studies.

The potential for tag burden to increase mortality due to barotrauma during passage may differ among the studies. The radio-tagged fish in $2012 \mathrm{had}$ an internal tag and a tag burden average of 1.2 percent (range 0.6-3.2 percent). When weight is added to juvenile salmonids they can gulp air at the water surface to increase the size of their swim bladder to regain a near-neutrally buoyant state, a process generally taking several hours (Fried and others, 1976). Internal tags reduce the space available for air bladder expansion and have been shown to increase the detrimental effects of barotrauma during simulated turbine passage (Carlson and others, 2012). Tags placed on the outside of a fish, such as those used in the studies based on balloon tags, also require swim bladder inflation to regain neutral buoyancy, but do not reduce the internal space available for expansion. PIT tags are much smaller and lighter than radio transmitters and generally are not assumed to affect fish survival during dam passage. As previously noted, passage through the RO at Cougar Dam does not present a significant risk of mortality due to barotrauma alone; however, presence of the internal radio transmitter could increase the effect of barotrauma. To evaluate this question, we used equation 1 from Carlson and others (2012) to estimate the probability of mortal injury during passage of radio-tagged fish through the RO at Cougar Dam during the November 2012 study. The model inputs were the acclimation pressure (we assumed a 
surface acclimation pressure of 15 psia), minimum exposure pressure (about 14 psia based on Duncan (2011)), and tag burden (maximum 3.2 percent-we use the maximum here rather than the average). The resulting probability of mortal injury during passage was 0.022 which is equivalent to 2.2 percent. From this result, we conclude that tag burden during dam passage is not an important source of the differences in survivals between the studies.

The passage conditions experienced by the fish may have differed among studies. Releasing fish through a hose directly into the desired route of passage is useful to study how specific conditions affect injury and survival, but the results can only be extrapolated to the population at large when the passage conditions experienced by the hose-released fish release represent those of volitionally passing fish. Extrapolating results from hose-released fish to the population generally is the goal of such studies and the release sites are carefully chosen, however, there have been instances when the hose-released fish did not represent the volitionally passing population. The balloon-tagged fish released near the ogee crest of the spillway weir at Ice Harbor Dam on the Snake River is one example. In that case, the survival of balloon-tagged fish released at a location close to the spillway ogee was lower than desired, and subsequent evaluation of untagged volitionally passing fish based on hydroacoustics showed that few fish passed near that location (Normandeau Associates, Inc. and Skalski, 2006; Ham and others, 2007). Different passage conditions between hose-released and volitionally passing fish are a plausible cause of the differences in survival estimates between the studies at Cougar Dam. The mechanism is a difference in the paths the tagged fish take as they enter the RO, pass the RO gate, and potentially through the pipe and chute, exposing them to different mortality pressures resulting in differences in survival. This could be tested by releasing tagged fish or by observing untagged fish as they enter the RO. Estimates of RO passage survival of a PIT-tagged group and a radio-tagged group (or other active tag type) of volitionally passing fish could be compared. Active tags have much higher detection probabilities than passive tags (such as PIT tags) and therefore require fewer tagged fish for studies such as these. It may be possible to monitor the paths of untagged fish entering the RO directly using acoustic cameras or indirectly using hydroacoustics either alternatively or in conjunction with a study of tagged fish. It also is possible that conditions inside the wet well of the tower contribute to different passage conditions of hose-released and volitionally passing fish, but this seems less likely than differences near the RO gate.

The results from these and previous studies indicate that entrainment and survival of juvenile salmonids passing Cougar Dam varies with dam operating conditions. The condition most conducive to dam passage has been the low pool elevation and discharge regime tested during December 2012. The highest dam passage survival has been for fish passing through the RO when the RO gate openings were large.

\section{Acknowledgments}

Many people assisted with this study. We wish to thank Rob Chitwood, Eric Billman, and other staff of the Wild Fish Surrogate project for providing the fish for the study, and the staff at Leaburg Fish Hatchery for providing space to hold them. Brian Ekstrom, Gabriel Hansen, Pete Kofoot, Dana Shurtleff, and Ryan Tomka of the USGS Columbia River Research Laboratory assisted with the field work. The staff at Cougar Dam assisted us in many ways. David Griffith at the U.S. Army Corps of Engineers Portland District provided insight and project support. Dr. John Plumb and Eric Hockersmith reviewed an earlier version of the report. This study was funded by the U.S. Army Corps of Engineers Portland District under contract WK66QKZ22296184. 


\section{References Cited}

Beeman, J.W., Braatz, A.C., Hansel, H.C., Fielding, S.D., Haner, P.V., Hansen, G.S., Shurtleff, D.J., Sprando, J.M., and Rondorf, D.W., 2010, Approach, passage, and survival of juvenile salmonids at Little Goose Dam, Washington-Post-construction evaluation of a temporary spillway weir, 2009: U.S. Geological Survey Open-File Report 2010-1224, 102 p., http://pubs.usgs.gov/of/2010/1224/.

Beeman, J.W., Grant, C., and Haner, P.V., 2004, Comparison of three underwater antennas for use in radio telemetry: North American Journal of Fisheries Management, v. 24, p. 275-281.

Beeman, J.W., Hansel, H.C., Hansen, A.C., Haner, P.V., Sprando, J.M., Smith, C.D., Evans, S.D., and Hatton, T.W., 2013, Behavior and dam passage of juvenile Chinook salmon at Cougar Reservoir and Dam, Oregon, March 2011-February 2012: U.S. Geological Survey Open-File Report 2013-1079, 48 p., http://pubs.usgs.gov/of/2013/1079/.

Beeman, J.W., Hansen, A.C., Evans, S.E., Haner, P.V., Hansel, H.C., and Smith, C.D., 2012, Passage probabilities of juvenile Chinook salmon through the powerhouse and regulating outlet at Cougar Dam, Oregon, 2011: U.S. Geological Survey Open-File Report 2012-1250, 26 p., http://pubs.usgs.gov/of/2012/1250/.

Beeman, J.W., and Perry, R.W., 2012, Bias from false-positive detections and strategies for their removal in studies using telemetry, in Adams, N.S., Beeman, J.W., and Eiler, J.H., eds., Telemetry techniques - A user guide for fisheries research: Bethesda, Maryland, American Fisheries Society, $p$. 505-518.

Bregge, D.A., Absolon, R.F., and Graves, R.J., 1996, Seasonal and diel passage of juvenile salmonids at John Day dam on the Columbia River: North American Journal of Fisheries Management v. 16, p. 659-665.

Burnham, K.P., and Anderson, D.R., 2002, Model selection and multimodel inference-A practical information-theoretic approach: New York, Springer-Verlag, 488 p.

Burnham, K.P., Anderson, D.R., White, G.C., Brownie, C., and Pollock, K.H., 1987, Design and analysis methods for fish survival experiments based on release-recapture: Bethesda, Maryland, American Fisheries Society, America Fisheries Society Monograph 5, 737 p.

Carlson, T.J., Brown, R.S., Stephenson, J.R., Pflugrath, B.D., Colotelo, A.H., Gingerich, A.J., Benjamin, P.A., Langeslay, M.J., Ahmann, M.A., Johnson, R.L., Skalski, J.R., Seaburg, A.G., and Townsend, R.L., 2012, The Influence of tag presence on the mortality of juvenile Chinook Salmon exposed to simulated hydroturbine passage-Implications for survival estimates and management of hydroelectric facilities: North American Journal of Fisheries Management, v. 32, p. 249-261.

Cormack, R.M., 1964, Estimates of survival from the sighting of marked animals: Biometrika, v.51, no. 3-4, p. 429-438.

Cowen, L., and Schwarz, C.J., 2005, Capture-recapture studies using radio telemetry with premature radio-tag failure: Biometrics, v. 61, p. 657-664.

Duncan, J.P, 2011, Characterization of fish passage conditions through a Francis turbine and regulating outlet at Cougar Dam, Oregon, using sensor fish, 2009-2010: Pacific Northwest Laboratory report PNNL-20408, 172 p.

Evans, S.D., and Stevenson, J.R., 2012, Optimization of radio telemetry receiving systems, in Adams, N.S., Beeman, J.W., and Eiler, J.H., eds., Telemetry techniques-A user guide for fisheries research: Bethesda, Maryland, American Fisheries Society, p. 139-162.

Ferguson, J.W., Absolon, R.F., Carlson, T.J., and Sandford, B.P., 2006, Evidence of delayed mortality on juvenile pacific salmon passing through turbines at Columbia River dams: Transactions of the American Fisheries Society, v. 135, p. 139-150. 
Fried, S.M., McLeave, J.D., and Stred, K.A., 1976, Buoyancy compensation by Atlantic salmon (Salmo salar) smolts tagged internally with dummy telemetry transmitters: Journal of the Fisheries Research Board of Canada v. 33, p. 1,377-1,380.

Ham, K.D., Titzler, P.S., Reese, S.P., and Moursund, R.A., 2007, Hydroacoustic evaluation of fish distributions at the Ice Harbor Dam removable spillway weir in 2006: Pacific Northwest National Laboratory report PNWD-3862, 55 p.

Hosmer, D.W., Jr., and Lemeshow, S., 1999, Applied survival analysis-Regression modeling of time to event data: New York, John Wiley and Sons, 386 p.

Jolly, G.M., 1965, Explicit estimates from capture-recapture data with both death and immigrationstochastic model: Biometrika, v. 52, no. 1/2, p. 225-247.

Lady, J.M., and Skalski, J.R., 2009, USER 4-User-specified estimation routine: Prepared for U.S. Department of Energy, Bonneville Power Administration, Portland, Oregon, Project No. 198910700, Portland, Oregon, 45 p., accessed October 25, 2012, at http://www.cbr.washington.edu/paramest/user/.

Monzyk, F., Heisey, P., Duncan, J., and Griffith, D., 2011, Draft executive summary to Willamette Action Team for Restoration, preliminary results for 2009-2010 downstream passage studies at Cougar Dam: Report to U.S. Army Corps of Engineers, Portland, Oregon, 22 p.

National Oceanic and Atmospheric Administration, 2008, Endangered Species Act section 7(a)(2) consultation biological opinion \& Magnuson-Stevens Fishery Conservation \& Management Act essential fish habitat consultation-Consultation on the "Willamette River Basin Flood Control Project", NOAA Fisheries Log Number: National Oceanic and Atmospheric Administration, FINWR12000/02117, June 11, 2008, accessed October 25, 2012, at http://www.nwr.noaa.gov/SalmonHydropower/Willamette-Basin/Willamette-BO.cfm.

Normandeau and Associates, Inc., and Skalski, J.R., 2006, Comparative direct survival and injury rates of juvenile salmon passing the new removable spillway weir (RSW) and a spillbay at Ice Harbor Dam, Snake River, Washington: Normandeau Associates, Inc., Prepared for U.S. Army Corps of Engineers, Portland District, Normandeau project number 18880.017, Portland, Oregon, 200 p.

Normandeau and Associates, Inc., 2010, Estimates of direct survival and injury of juvenile Chinook salmon (Oncorhynchus tshawytscha), passing a regulating outlet and turbine at Cougar Dam, Oregon: Normandeau Associates, Inc., Prepared for U.S. Army Corps of Engineers, Portland District, contract 912EF-08-D-0005 task order DT01, Portland, Oregon, 160 p.

Ploskey, G.R., Batten III, G.R., Cushing, A.W., Kim, J., Johnson, G.E., Skalski, J.R., Townsend, R.L., Seaburg, A.G., Carlson, T.J., Carpenter, S.M., Deng, Z., Etherington, D.J., Fischer, E.S., Fu, T., Greiner, M.J., Hennen, M.J., Hughes, J.H., Martinez, J.J., Mitchell, T.D., Rayamajhi, B., Weiland, M.A., Woodley, C.M., and Zimmerman, S.A., 2013, Survival and Passage of Juvenile Chinook Salmon and Steelhead Passing Through Bonneville Dam, 2010: Pacific Northwest National Laboratory draft final report PNNL-22178, 210 p.

Seber, G.A.F., 1965, A note on the multiple recapture census: Biometrika, v. 52, no. 1/2. p. $249-259$.

Skalski, J.R., Townsend, R., Lady, J., Giorgi, A.E., Stevenson, J.R., and McDonald, R.S., 2002, Estimating route-specific passage and survival probabilities at a hydroelectric project from smolt radiotelemetry studies: Canadian Journal of Fisheries and Aquatic Sciences, v. 59, p. 1,385-1,393. Skalski, J.R., Seaburg, A.G., and Buchanan, R.A., 2013a, The effects of high detection probabilities on model selection in paired release-recapture studies in the era of electronic tagging studies: Animal Biotelemetry, v. 1, no. 12. 
Skalski, J.R., Townsend, R.L., Seaburg, A.G., McMichael, G.A., Oldenburg, E.W., Harnish, R.A., Ham, K.D., Colotelo, A.H., Deters, K.A., and Deng, Z.D., 2013b, BiOp performance testing-Passage and survival of yearling and subyearling Chinook salmon and juvenile steelhead at Little Goose Dam, 2012: Pacific Northwest National Laboratory draft report PNNL-22140, 130 p.

Surgical Protocol Steering Committee, 2011, Surgical protocols for implanting JSATS transmitters into juvenile salmonids for studies conducted for the U.S. Army Corps of Engineers: Surgical Protocols Steering Committee, Report prepared for U.S. Army Corps of Engineers, Portland, Oregon, 18 p. Townsend, R.L., Skalski, J.R., Dillingham, P., and Steig, T.W., 2006, Correcting bias in survival estimation resulting from tag failure in acoustic and radiotelemetry studies: Journal of Agricultural, Biological, and Environmental Statistics, v. 11, p. 183-196.

White, G.C., and Burnham, K.P., 1999, Program MARK-Survival estimation from populations of marked animals: Bird Study, v. 46, Supplement, p. 120-138. 


\section{Appendix A. Type and Location of Radio-Telemetry Detection Sites}

[Yagi is a type of aerial antenna. Coax refers to an underwater stripped coaxial cable. Latitude and Longitude are degrees, minutes, and hundredths of minutes]

\begin{tabular}{|c|c|c|c|c|}
\hline Number & Name & Antenna type, number & Latitude & Longitude \\
\hline 1 & Forebay & Yagi, 2 & $440739.32 \mathrm{~N}$ & $1221440.67 \mathrm{~W}$ \\
\hline 2 & Inside Temperature Control tower & Coax, 3 & $440738.58 \mathrm{~N}$ & $1221440.90 \mathrm{~W}$ \\
\hline \multirow[t]{4}{*}{3} & Powerhouse tailrace $^{1}$ & & & \\
\hline & Antenna 1 & Yagi, 1 & $440753.38 \mathrm{~N}$ & $1221437.00 \mathrm{~W}$ \\
\hline & Antenna 2 & Yagi, 1 & $440755.18 \mathrm{~N}$ & $1221435.55 \mathrm{~W}$ \\
\hline & Antenna 3 & Yagi, 1 & $440756.82 \mathrm{~N}$ & $1221435.48 \mathrm{~W}$ \\
\hline \multirow[t]{4}{*}{4} & Regulating outlet tailrace $^{1}$ & & & \\
\hline & Antenna 1 & Yagi, 1 & $440753.35 \mathrm{~N}$ & $1221438.88 \mathrm{~W}$ \\
\hline & Antenna 2 & Yagi, 1 & $440754.61 \mathrm{~N}$ & $1221438.23 \mathrm{~W}$ \\
\hline & Antenna 3 & Yagi, 1 & $440756.77 \mathrm{~N}$ & $1221437.42 \mathrm{~W}$ \\
\hline \multirow[t]{2}{*}{5} & South Fork McKenzie River at Aufderheide & & & \\
\hline & Road Bridge & Yagi, 1 & $440925.00 \mathrm{~N}$ & $1221543.98 \mathrm{~W}$ \\
\hline \multirow[t]{2}{*}{6} & McKenzie River near South Fork McKenzie & & & \\
\hline & River & Yagi, 1-3 & $440904.31 \mathrm{~N}$ & $1221905.99 \mathrm{~W}$ \\
\hline \multirow[t]{4}{*}{7} & McKenzie River at Leaburg Dam ${ }^{1}$ & & & \\
\hline & West bank & Yagi, 2 & $440814.89 \mathrm{~N}$ & $1223645.22 \mathrm{~W}$ \\
\hline & East bank & Yagi, 2 & $440815.25 \mathrm{~N}$ & $1223639.96 \mathrm{~W}$ \\
\hline & Juvenile fish bypass & Coax, 4 & $440813.36 \mathrm{~N}$ & $1223644.94 \mathrm{~W}$ \\
\hline 8 & Willamette River at Marshall Island Park & Yagi, 2 & $441120.40 \mathrm{~N}$ & $1230849.62 \mathrm{~W}$ \\
\hline 9 & Willamette River at Rogue Hops Farm ${ }^{1}$ & Yagi, 2 & $444817.48 \mathrm{~N}$ & $1230538.38 \mathrm{~W}$ \\
\hline
\end{tabular}

${ }^{1}$ Two identical systems at this site. 


\section{Appendix B. Summaries of the Allocation of Tagger Effort and the Numbers and Sizes of Fish Released during the November and December Studies}

Table B1. Summary of the numbers of fish tagged by each tagger for each release time (Release), rearing group (Group), and release type, Cougar Dam, Oregon, November 2012 study.

[Release format is CGR followed by mmdd-time, where mmdd-time is the month, day, and AM or PM release group. Release types are reservoir (RES), treatment (TRT), control (CON), and euthanized (EUT)]

\begin{tabular}{|c|c|c|c|c|c|c|c|c|c|c|c|}
\hline \multirow[b]{2}{*}{ Release } & \multirow[b]{2}{*}{ Group } & \multicolumn{5}{|c|}{ Tagger 1} & \multicolumn{5}{|c|}{ Tagger 2} \\
\hline & & RES & TRT & CON & EUT & Total & RES & TRT & CON & EUT & Total \\
\hline CGR1106- AM & A & 3 & 11 & 5 & 1 & 20 & 3 & 11 & 5 & 2 & 21 \\
\hline CGR1106- AM & B & 3 & 11 & 5 & 1 & 20 & 3 & 11 & 5 & 1 & 20 \\
\hline CGR1106- PM & A & 3 & 12 & 5 & 0 & 20 & 3 & 12 & 5 & 0 & 20 \\
\hline CGR1106- PM & B & 3 & 6 & 11 & 0 & 20 & 4 & 12 & 5 & 0 & 21 \\
\hline CGR1107- AM & A & 3 & 12 & 5 & 2 & 22 & 3 & 11 & 5 & 1 & 20 \\
\hline CGR1107- AM & B & 3 & 11 & 5 & 1 & 20 & 3 & 11 & 5 & 1 & 20 \\
\hline CGR1107-PM & A & 4 & 12 & 6 & 0 & 22 & 3 & 12 & 6 & 0 & 21 \\
\hline CGR1107- PM & B & 3 & 12 & 4 & 0 & 19 & 3 & 12 & 4 & 0 & 19 \\
\hline CGR1108- AM & A & 3 & 11 & 5 & 0 & 19 & 3 & 12 & 5 & 0 & 20 \\
\hline CGR1108- AM & B & 3 & 11 & 5 & 0 & 19 & 3 & 11 & 5 & 0 & 19 \\
\hline CGR1108- PM & A & 3 & 11 & 6 & 1 & 21 & 4 & 12 & 5 & 1 & 22 \\
\hline CGR1108- PM & B & 3 & 13 & 5 & 2 & 23 & 3 & 12 & 5 & 1 & 21 \\
\hline CGR1109- AM & A & 3 & 11 & 5 & 1 & 20 & 3 & 11 & 5 & 1 & 20 \\
\hline CGR1109- AM & B & 3 & 11 & 5 & 1 & 20 & 3 & 11 & 5 & 2 & 21 \\
\hline CGR1109- PM & A & 3 & 12 & 5 & 0 & 20 & 3 & 12 & 5 & 0 & 20 \\
\hline CGR1109- PM & B & 4 & 12 & 5 & 0 & 21 & 3 & 12 & 5 & 0 & 20 \\
\hline CGR1110- AM & A & 3 & 11 & 5 & 2 & 21 & 3 & 12 & 5 & 1 & 21 \\
\hline CGR1110- AM & B & 3 & 12 & 5 & 1 & 21 & 3 & 10 & 5 & 1 & 19 \\
\hline CGR1110- PM & A & 3 & 12 & 5 & 0 & 20 & 3 & 12 & 5 & 0 & 20 \\
\hline CGR1110- PM & B & 3 & 12 & 5 & 0 & 20 & 4 & 12 & 5 & 0 & 21 \\
\hline Total Group A & & 31 & 115 & 52 & 7 & 205 & 31 & 117 & 51 & 6 & 205 \\
\hline $\begin{array}{l}\text { Total Group B } \\
\text { Grand total }\end{array}$ & & 31 & 111 & 55 & 6 & $\begin{array}{l}203 \\
408\end{array}$ & 32 & 114 & 49 & 6 & $\begin{array}{l}201 \\
406\end{array}$ \\
\hline
\end{tabular}


Table B2. Summary of the numbers of fish tagged by each tagger for each release time (Release), rearing group (Group), and release type, Cougar Dam, Oregon, December 2013 study.

[Release format is CGR followed by mmdd-time, where mmdd-time is the month, day, and AM or PM release group. Release types are reservoir (RES), treatment (TRT), control (CON), and euthanized (EUT)]

\begin{tabular}{|c|c|c|c|c|c|c|c|c|c|c|c|}
\hline \multirow[b]{2}{*}{ Release } & \multirow[b]{2}{*}{ Group } & \multicolumn{5}{|c|}{ Tagger 1} & \multicolumn{5}{|c|}{ Tagger 2} \\
\hline & & RES & TRT & CON & EUT & Total & RES & TRT & CON & EUT & Total \\
\hline CGR1218-AM & $\mathrm{A}$ & 3 & 12 & 5 & 0 & 20 & 2 & 12 & 5 & 0 & 19 \\
\hline CGR1218-AM & B & 3 & 11 & 5 & 0 & 19 & 4 & 11 & 5 & 0 & 20 \\
\hline CGR1218-PM & A & 3 & 12 & 5 & 1 & 21 & 6 & 12 & 5 & 2 & 25 \\
\hline CGR1218-PM & B & 1 & 11 & 5 & 1 & 18 & 0 & 7 & 5 & 1 & 13 \\
\hline CGR1219-AM & $\mathrm{A}$ & 3 & 11 & 5 & 1 & 20 & 3 & 11 & 5 & 1 & 20 \\
\hline CGR1219-AM & B & 3 & 11 & 5 & 2 & 21 & 3 & 12 & 5 & 1 & 21 \\
\hline CGR1219-PM & $\mathrm{A}$ & 2 & 5 & 4 & 0 & 11 & 3 & 7 & 5 & 0 & 15 \\
\hline CGR1219-PM & B & 4 & 13 & 3 & 0 & 20 & 4 & 11 & 3 & 0 & 18 \\
\hline CGR1220-AM & $\mathrm{A}$ & 3 & 11 & 5 & 0 & 19 & 3 & 10 & 5 & 0 & 18 \\
\hline CGR1220-AM & B & 3 & 11 & 5 & 0 & 19 & 3 & 13 & 5 & 0 & 21 \\
\hline CGR1220-PM & $\mathrm{A}$ & 5 & 12 & 5 & 2 & 24 & 3 & 11 & 5 & 1 & 20 \\
\hline CGR1220-PM & B & 2 & 13 & 5 & 1 & 21 & 3 & 14 & 5 & 1 & 23 \\
\hline CGR1221-AM & $\mathrm{A}$ & 3 & 11 & 6 & 1 & 21 & 3 & 7 & 5 & 2 & 17 \\
\hline CGR1221-AM & B & 3 & 12 & 4 & 1 & 20 & 3 & 11 & 5 & 1 & 20 \\
\hline CGR1221-PM & A & 3 & 13 & 4 & 0 & 20 & 4 & 17 & 5 & 0 & 26 \\
\hline CGR1221-PM & B & 3 & 13 & 6 & 0 & 22 & 3 & 15 & 5 & 0 & 23 \\
\hline CGR1222-AM & A & 2 & 5 & 3 & 0 & 10 & 1 & 8 & 2 & 1 & 12 \\
\hline CGR1222-AM & B & 3 & 9 & 1 & 2 & 15 & 3 & 9 & 2 & 2 & 16 \\
\hline CGR1222-PM & $\mathrm{A}$ & 1 & 5 & 3 & 0 & 9 & 1 & 7 & 2 & 0 & 10 \\
\hline CGR1222-PM & B & 3 & 7 & 9 & 0 & 19 & 3 & 4 & 5 & 0 & 12 \\
\hline Total Group A & & 28 & 97 & 45 & 5 & 175 & 29 & 102 & 44 & 7 & 182 \\
\hline Total Group B & & 28 & 111 & 48 & 7 & 194 & 29 & 107 & 45 & 6 & 187 \\
\hline Grand total & & & & & & 369 & & & & & 369 \\
\hline
\end{tabular}


Table B3. Summary statistics of fork length $(\mathrm{mm})$ and weight $(\mathrm{g})$ of radio- and PIT-tagged juvenile Chinook salmon released in the reservoir upstream of Cougar Dam, Oregon, November and December, 2012.

[N, number of fish collected; SD, standard deviation $]$

\begin{tabular}{|c|c|c|c|c|c|c|c|}
\hline \multirow[t]{2}{*}{ Release date and time } & \multicolumn{4}{|c|}{ Fork length } & \multicolumn{3}{|c|}{ Weight } \\
\hline & $N$ & Mean & SD & Range & Mean & SD & Range \\
\hline $11 / 6 / 1213: 59$ & 12 & 148.3 & 14.2 & $118-172$ & 37.3 & 10.3 & $19.8-53.4$ \\
\hline 11/6/12 19:11 & 13 & 152.1 & 7.7 & $140-166$ & 38.6 & 6.5 & $29.8-50.8$ \\
\hline $11 / 7 / 1214: 42$ & 12 & 142.3 & 15.0 & $115-163$ & 32.1 & 9.1 & $18.9-47.8$ \\
\hline $11 / 7 / 12 \quad 17: 53$ & 13 & 147.2 & 15.4 & $120-163$ & 34.6 & 10.5 & $19.6-50.5$ \\
\hline $11 / 8 / 1214: 10$ & 12 & 143.5 & 14.0 & $120-169$ & 32.4 & 10.2 & $18.9-53.9$ \\
\hline $11 / 8 / 12 \quad 17: 47$ & 13 & 146.9 & 10.7 & $131-172$ & 33.4 & 6.6 & $24.0-48.7$ \\
\hline 11/9/12 11:05 & 12 & 148.8 & 13.8 & $131-174$ & 35.3 & 10.9 & $21.8-53.8$ \\
\hline $11 / 9 / 1217: 56$ & 13 & 144.9 & 17.3 & $119-173$ & 34.3 & 13.6 & $15.6-67.2$ \\
\hline $11 / 10 / 1210: 31$ & 12 & 147.7 & 14.0 & $120-168$ & 35.1 & 10.1 & $18.2-55.9$ \\
\hline $11 / 10 / 1217: 30$ & 13 & 148.4 & 9.9 & $132-167$ & 35.8 & 8.9 & $26.2-56.0$ \\
\hline $12 / 18 / 1215: 07$ & 12 & 168.1 & 9.8 & $152-179$ & 48.3 & 8.0 & $37.8-59.1$ \\
\hline $12 / 18 / 1219: 57$ & 10 & 167.0 & 14.6 & $128-180$ & 49.8 & 11.2 & $22.4-63.8$ \\
\hline 12/19/12 14:12 & 12 & 152.4 & 19.8 & $118-176$ & 39.5 & 15.2 & $18.4-59.4$ \\
\hline $12 / 19 / 12 \quad 17: 30$ & 13 & 158.1 & 15.3 & $134-177$ & 42.1 & 10.7 & $25.6-55.7$ \\
\hline $12 / 20 / 1212: 56$ & 12 & 161.8 & 9.7 & $144-177$ & 44.9 & 8.9 & $30.7-58.3$ \\
\hline $12 / 20 / 12$ 17:54 & 13 & 165.9 & 10.5 & $150-180$ & 47.8 & 10.6 & $31.8-62.0$ \\
\hline $12 / 21 / 1213: 13$ & 12 & 168.5 & 10.1 & $143-180$ & 49.3 & 9.6 & $30.1-63.4$ \\
\hline $12 / 21 / 1218: 24$ & 13 & 159.5 & 17.1 & $132-180$ & 43.5 & 14.4 & $25.2-64.4$ \\
\hline $12 / 22 / 12$ 11:42 & 9 & 154.0 & 15.2 & $125-168$ & 39.3 & 12.1 & $20.3-52.7$ \\
\hline $12 / 22 / 1218: 06$ & 8 & 158.8 & 15.1 & $128-174$ & 41.6 & 11.7 & $22.3-59.7$ \\
\hline Overall & 239 & 154.0 & 15.6 & $115-180$ & 39.5 & 11.7 & $15.6-67.2$ \\
\hline
\end{tabular}


Table B4. Summary statistics of fork length $(\mathrm{mm})$ and weight $(\mathrm{g})$ of radio- and PIT-tagged juvenile Chinook salmon released near the temperature control tower at Cougar Dam, Oregon, November and December 2012.

[N, number of fish collected; SD, standard deviation $]$

\begin{tabular}{|c|c|c|c|c|c|c|c|}
\hline \multirow[t]{2}{*}{ Release date and time } & \multicolumn{4}{|c|}{ Fork length } & \multicolumn{3}{|c|}{ Weight } \\
\hline & $N$ & Mean & SD & Range & Mean & SD & Range \\
\hline 11/6/12 13:39 & 44 & 148.0 & 15.6 & $105-178$ & 36.5 & 11.4 & $12.7-62.9$ \\
\hline 11/6/12 19:32 & 42 & 145.8 & 13.6 & $116-174$ & 34.7 & 9.6 & $16.3-52.7$ \\
\hline $11 / 7 / 1214: 15$ & 45 & 146.8 & 9.8 & $121-165$ & 34.7 & 6.5 & $20.5-49.4$ \\
\hline $11 / 7 / 1217: 31$ & 48 & 148.6 & 15.5 & $114-174$ & 36.3 & 10.6 & $16.2-56.1$ \\
\hline $11 / 8 / 1214: 47$ & 45 & 146.2 & 14.0 & $110-168$ & 34.6 & 10.2 & $15.0-62.6$ \\
\hline 11/8/12 18:06 & 48 & 148.0 & 14.1 & $114-178$ & 35.8 & 10.7 & $15.9-59.7$ \\
\hline $11 / 9 / 12 \quad 10: 24$ & 44 & 146.3 & 14.0 & $110-167$ & 33.1 & 8.5 & $13.1-46.8$ \\
\hline $11 / 9 / 12 \quad 17: 32$ & 48 & 149.8 & 13.5 & $115-170$ & 36.4 & 9.8 & $15.0-66.8$ \\
\hline $11 / 10 / 12 \quad 10: 50$ & 45 & 152.7 & 14.2 & $107-179$ & 39.4 & 10.5 & $13.2-68.6$ \\
\hline $11 / 10 / 1217: 55$ & 48 & 151.7 & 13.0 & $116-177$ & 37.4 & 10.5 & $16.3-60.1$ \\
\hline 12/18/12 14:41 & 46 & 161.0 & 11.8 & $132-180$ & 44.0 & 10.2 & $22.6-66.8$ \\
\hline $12 / 18 / 1219: 57$ & 42 & 161.5 & 14.0 & $129-180$ & 45.8 & 11.3 & $22.3-63.5$ \\
\hline 12/19/12 15:00 & 45 & 163.3 & 14.7 & $120-180$ & 46.6 & 11.7 & $17.8-66.4$ \\
\hline $12 / 19 / 1217: 51$ & 36 & 163.2 & 15.1 & $126-180$ & 46.5 & 11.9 & $20.6-66.5$ \\
\hline $12 / 20 / 12 \quad 12: 31$ & 45 & 162.7 & 15.0 & $122-180$ & 45.4 & 11.1 & $19.4-62.7$ \\
\hline $12 / 20 / 12 \quad 17: 30$ & 50 & 161.8 & 15.6 & $119-180$ & 45.7 & 12.2 & $18.5-72.3$ \\
\hline $12 / 21 / 1213: 33$ & 41 & 158.6 & 16.1 & $120-180$ & 42.9 & 12.9 & $17.6-66.9$ \\
\hline $12 / 21 / 1218: 50$ & 58 & 161.9 & 14.4 & $120-180$ & 44.6 & 10.7 & $16.8-60.0$ \\
\hline $12 / 22 / 1211: 14$ & 31 & 154.4 & 15.1 & $112-179$ & 39.1 & 10.4 & $16.1-59.8$ \\
\hline $12 / 22 / 1217: 34$ & 23 & 153.5 & 18.0 & $114-176$ & 38.5 & 12.6 & $15.2-57.7$ \\
\hline Overall & 874 & 154.3 & 15.7 & $105-180$ & 39.9 & 11.6 & $12.7-72.3$ \\
\hline
\end{tabular}


Table B5. Summary statistics of fork length $(\mathrm{mm})$ and weight $(\mathrm{g})$ of radio- and PIT-tagged juvenile Chinook salmon released alive in the tailrace at Cougar Reservoir, Oregon, November and December 2012.

[N, number of fish collected; SD, standard deviation $]$

\begin{tabular}{|c|c|c|c|c|c|c|c|}
\hline \multirow[t]{2}{*}{ Release date and time } & \multicolumn{4}{|c|}{ Fork length } & \multicolumn{3}{|c|}{ Weight } \\
\hline & $N$ & Mean & SD & Range & Mean & SD & Range \\
\hline $11 / 6 / 1215: 23$ & 26 & 150.3 & 12.0 & $121-167$ & 37.2 & 8.3 & $21.7-54.4$ \\
\hline $11 / 6 / 12 \quad 17: 22$ & 20 & 142.6 & 12.5 & $123-164$ & 31.7 & 8.4 & $20.2-53.2$ \\
\hline $11 / 7 / 1213: 15$ & 20 & 148.3 & 11.4 & $127-165$ & 34.2 & 8.7 & $22.9-53.1$ \\
\hline 11/7/12 19:07 & 20 & 148.7 & 12.5 & $128-167$ & 36.9 & 9.6 & $22.7-55.2$ \\
\hline $11 / 8 / 1212: 28$ & 20 & 154.5 & 9.7 & $133-178$ & 40.7 & 9.3 & $25.6-62.9$ \\
\hline 11/8/12 19:09 & 20 & 152.2 & 8.2 & $128-165$ & 39.1 & 6.0 & $24.0-47.1$ \\
\hline 11/9/12 9:23 & 20 & 142.1 & 14.7 & $110-170$ & 31.3 & 8.8 & $15.5-48.2$ \\
\hline 11/9/12 19:06 & 20 & 146.7 & 10.9 & $123-165$ & 33.7 & 7.7 & $20.5-48.3$ \\
\hline $11 / 10 / 129: 14$ & 20 & 148.5 & 12.0 & $121-177$ & 35.6 & 10.0 & $19.4-63.0$ \\
\hline $11 / 10 / 1219: 37$ & 20 & 149.1 & 13.5 & $118-175$ & 36.6 & 11.2 & $18.2-61.3$ \\
\hline $12 / 18 / 12 \quad 17: 12$ & 20 & 161.8 & 15.0 & $129-179$ & 46.0 & 11.7 & $24.4-65.3$ \\
\hline 12/18/12 18:02 & 20 & 164.8 & 9.2 & $144-178$ & 47.6 & 7.8 & $29.6-61.2$ \\
\hline $12 / 19 / 1211: 58$ & 20 & 159.0 & 14.4 & $129-179$ & 42.5 & 10.4 & $22.3-61.7$ \\
\hline 12/19/12 19:01 & 15 & 165.7 & 8.5 & $151-180$ & 48.0 & 8.4 & $34.9-64.7$ \\
\hline $12 / 20 / 12 \quad 10: 52$ & 20 & 159.6 & 15.7 & $118-180$ & 43.8 & 11.8 & $17.5-62.8$ \\
\hline $12 / 20 / 1219: 13$ & 20 & 163.7 & 13.8 & $132-180$ & 46.4 & 11.7 & $22.8-65.0$ \\
\hline $12 / 21 / 12 \quad 14: 47$ & 20 & 160.5 & 17.5 & $115-179$ & 44.1 & 13.5 & $16.0-64.0$ \\
\hline $12 / 21 / 1217: 46$ & 20 & 161.7 & 15.2 & $127-180$ & 44.3 & 12.1 & $20.2-60.8$ \\
\hline $12 / 22 / 12 \quad 10: 01$ & 8 & 143.5 & 18.4 & $126-174$ & 31.7 & 12.1 & $21.6-54.4$ \\
\hline $12 / 22 / 12 \quad 19: 24$ & 19 & 158.6 & 14.5 & $120-178$ & 41.3 & 10.2 & $17.3-58.6$ \\
\hline Overall & 388 & 154.2 & 14.7 & $110-180$ & 39.3 & 11.1 & $15.5-65.3$ \\
\hline
\end{tabular}

Table B6. Summary statistics of fork length $(\mathrm{mm})$ and weight $(\mathrm{g})$ of radio- and PIT-tagged juvenile Chinook salmon euthanized and released in the tailrace at Cougar Reservoir, Oregon, November and December 2012.

$[N$, number of fish collected; SD, standard deviation $]$

\begin{tabular}{|c|c|c|c|c|c|c|c|}
\hline \multirow[t]{2}{*}{ Release date and time } & \multicolumn{4}{|c|}{ Fork length } & \multicolumn{3}{|c|}{ Weight } \\
\hline & $N$ & Mean & SD & Range & Mean & SD & Range \\
\hline $11 / 6 / 12 \quad 15: 23$ & 5 & 145.6 & 13.5 & $130-163$ & 33.6 & 9.3 & $21.7-43.4$ \\
\hline $11 / 7 / 1213: 15$ & 5 & 146.8 & 10.1 & $132-158$ & 32.8 & 7.2 & $23.3-40.1$ \\
\hline 11/8/12 19:09 & 5 & 155.4 & 13.8 & $136-174$ & 40.8 & 12.0 & $24.6-56.2$ \\
\hline $11 / 9 / 129: 23$ & 5 & 154.6 & 13.9 & $136-171$ & 38.8 & 11.0 & $24.5-52.3$ \\
\hline $11 / 10 / 129: 14$ & 5 & 148.0 & 15.9 & $127-170$ & 35.8 & 10.8 & $22.5-51.5$ \\
\hline 12/18/12 18:02 & 5 & 154.4 & 13.5 & $136-170$ & 38.9 & 7.9 & $28.8-49.0$ \\
\hline $12 / 19 / 1211: 58$ & 5 & 151.6 & 21.4 & $124-176$ & 38.2 & 15.8 & $19.6-57.7$ \\
\hline 12/20/12 19:13 & 5 & 158.2 & 20.7 & $125-180$ & 43.9 & 16.1 & $20.5-63.3$ \\
\hline $12 / 21 / 12 \quad 14: 47$ & 5 & 159.0 & 15.9 & $133-172$ & 43.2 & 12.6 & $24.5-54.6$ \\
\hline 12/22/12 10:01 & 5 & 156.0 & 27.8 & $125-180$ & 42.7 & 21.0 & $20.6-64.6$ \\
\hline Overall & 50 & 153.0 & 16.3 & $124-180$ & 38.9 & 12.3 & $19.6-64.6$ \\
\hline
\end{tabular}




\section{Appendix C. Comparisons of Fish from the Two Rearing Groups}

\section{Introduction}

The fish used in these studies were reared as part of the Wild Fish Surrogate project conducted by Oregon State University. The goal of the Wild Fish Surrogate project, funded by the USACE, is to provide fish for studies of fish behavior and passage at Willamette River reservoirs. There were not enough fish from a single rearing group to provide fish for both the November and December studies because of the late inception of the studies. There were, however, adequate numbers of fish to conduct each study with fish from a unique rearing group, or if each study was conducted with fish from both rearing groups. We chose the latter scenario so we could compare the results of the November and December studies without the confounding effects of rearing group. This approach enabled an examination of the effects of rearing group on the results of each study.

The fish were progeny of hatchery spring Chinook salmon that returned to the North Santiam River, Oregon in the fall of 2011. The fish were fed either Abernathy Diet or Wild Chinook Grower Diet. Fish from each of the two diet groups were used in nearly equal numbers during each study. Fish used in the November study were reared at the Fish Performance and Genetics Laboratory in Corvallis, Oregon. For the December study fish fed the commercial diet were reared at the Fish Performance and Genetics Laboratory and fish fed the experimental diet were reared at the Oregon Hatchery Research Center in Alsea, Oregon. Fish from the two combinations of feed type and rearing site will hereafter be called rearing group A (Abernathy Diet) and rearing group B (Wild Chinook Grower Diet).

\section{Fish Size}

There were statistically significant differences in the fish sizes between rearing groups and study periods. In November, the size of the fish from rearing group A (mean FL $146.9 \mathrm{~mm}$, range 105-179 $\mathrm{mm}$ ) was significantly smaller than that of rearing group B (mean FL $149.6 \mathrm{~mm}$, range 107-178 mm; 1way General Linear Model $(\mathrm{GLM}), \mathrm{df}=1,787, \mathrm{~F}=8.25, P=0.0042)$, but in December the fish in group A (mean FL $163.1 \mathrm{~mm}$, range 114-180 mm) were significantly larger than those in group B (mean FL 158.8, range 112-180 mm; 1-way GLM, $\mathrm{df}=1,711, \mathrm{~F}=14.82, P=0.0001$ ). The FL of the tagged fish released in November was significantly smaller than those released in December (mean November 149.2 mm, December 160.9 mm; 1-way General Linear Model, df=1, 1500, $\mathrm{F}=304.95, P<0.0001)$.

\section{Travel Times}

During the November study, the travel times of fish from the two rearing groups were similar in most comparisons. There were no significant differences $(P<0.05)$ in travel times of rearing groups A and $\mathrm{B}$ within the treatment or control groups (tables $\mathrm{C} 1, \mathrm{C} 2)$. There were significant differences in travel times of rearing groups $\mathrm{A}$ and $\mathrm{B}$ released in the reservoir in two of the eight comparisons, but the results were often based on very small sample sizes (table C3). 
During the December study, there were statistically significant differences in travel times of the two rearing groups. For fish in the treatment group, the travel time distribution of group A indicated significantly faster migration than group B in all but the last reach (table C4). The differences in their median travel times ranged from less than $0.01 \mathrm{~d}$ from release to the tailrace to $0.47 \mathrm{~d}$ through the 71.2 $\mathrm{km}$ Leaburg Dam-to-Marshall Island reach. There were also significant differences in travel time distributions in three of the six comparisons for the control group. For the control group, fish from group A traveled significantly faster in two of the four reaches examined (table C5). The differences in median travel times ranged from $0.04 \mathrm{~d}$ in the release-to-Aufderheide Bridge reach to $0.20 \mathrm{~d}$ in the 71.2 $\mathrm{km}$ Leaburg Dam-to-Marshall Island reach. There were no significant differences in the travel time distributions of groups A and B released in the reservoir (table C6).

Table C1. Results of Wilcoxon tests comparing travel time distributions of rearing groups $A$ and $B$ fish released at the temperature control tower at Cougar Dam, Oregon, November 6-10, 2012.

[ $\chi^{2}$ is Chi Square, $P$ is probability, $>$ is greater than, the numerator degrees of freedom was 1 in each comparison]

\begin{tabular}{lrrrrr}
\hline & \multicolumn{3}{c}{ Sample size } & & \\
\cline { 2 - 3 } \multicolumn{1}{c}{ Reach } & Group & Group & & \\
& A & \multicolumn{1}{c}{$\mathbf{B}$} & $\mathbf{X}^{2}$ & $\mathbf{P}^{>} \mathbf{X}^{2}$ \\
\hline Release to tailrace & 156 & 147 & 0.09 & 0.7621 \\
Tailrace to Aufderheide Bridge & 88 & 77 & 0.16 & 0.6901 \\
Aufderheide Bridge to McKenzie River & 56 & 58 & 1.72 & 0.1896 \\
McKenzie River to Leaburg Dam & 42 & 44 & 2.73 & 0.0983 \\
Leaburg Dam to Marshall Island & 34 & 49 & 3.69 & 0.0549 \\
Marshall Island to Hops Farm & 27 & 31 & 0.50 & 0.4781 \\
& & & & \\
Release to Hops Farm & 36 & 36 & 0.00 & 0.9641 \\
\hline
\end{tabular}

Table C2. Results of Wilcoxon tests comparing travel time distributions of rearing groups $A$ and $B$ fish released into the tailrace of Cougar Dam, Oregon, November 6-10, 2012.

[ $\chi^{2}$ is Chi Square, $P$ is probability, $>$ is greater than, the numerator degrees of freedom was 1 in each comparison]

\begin{tabular}{lccccc}
\hline & \multicolumn{3}{c}{ Sample size } & & \\
\cline { 2 - 3 } \multicolumn{1}{c}{ Reach } & Group & Group & & \\
& A & B & $\mathbf{X}^{2}$ & $\boldsymbol{P}_{\boldsymbol{>} \mathbf{X}^{2}}$ \\
\hline Release to Aufderheide Bridge & 91 & 85 & 0.41 & 0.5241 \\
Aufderheide Bridge to McKenzie River & 69 & 62 & 0.74 & 0.3911 \\
McKenzie River to Leaburg Dam & 56 & 58 & 0.14 & 0.7129 \\
Leaburg Dam to Marshal Island & 46 & 53 & 0.01 & 0.9053 \\
Marshall Island to Hops Farm & 43 & 49 & 0.11 & 0.7398 \\
& & & & \\
Release to Hops Farm & 55 & 58 & 2.02 & 0.1550 \\
\hline
\end{tabular}


Table C3. Results of Wilcoxon tests comparing travel time distributions of rearing groups $A$ and $B$ fish released into Cougar Reservoir, Oregon, November 6-10, 2012.

[ $\chi^{2}$ is Chi Square, $P$ is probability, $>$ is greater than, the numerator degrees of freedom was 1 in each comparison]

\begin{tabular}{|c|c|c|c|c|}
\hline \multirow[b]{2}{*}{ Reach } & \multicolumn{2}{|c|}{ Sample size } & \multirow[b]{2}{*}{$x^{2}$} & \multirow[b]{2}{*}{$P>X^{2}$} \\
\hline & $\begin{array}{c}\text { Group } \\
\text { A }\end{array}$ & $\begin{array}{c}\text { Group } \\
\text { B }\end{array}$ & & \\
\hline Release to forebay & 53 & 53 & 0.11 & 0.7400 \\
\hline Release to tailrace & 35 & 40 & 0.09 & 0.7660 \\
\hline Tailrace to Aufderheide Bridge & 9 & 25 & 0.28 & 0.5938 \\
\hline Aufderheide Bridge to McKenzie River & 3 & 13 & 8.01 & 0.0047 \\
\hline McKenzie River to Leaburg Dam & 1 & 8 & 1.00 & 0.3173 \\
\hline Leaburg Dam to Marshall Island & 2 & 10 & 0.34 & 0.5582 \\
\hline Marshall Island to Hops Farm & 4 & 12 & 7.32 & 0.0068 \\
\hline Release to Hops Farm & 7 & 13 & 0.13 & 0.7229 \\
\hline
\end{tabular}

Table C4. Results of Wilcoxon tests comparing travel time distributions of rearing groups $A$ and $B$ fish released at the temperature control tower at Cougar Dam, Oregon, December 18-22, 2012.

[ $\chi^{2}$ is Chi Square, $P$ is probability, $>$ is greater than, the numerator degrees of freedom was 1 in each comparison]

\begin{tabular}{|c|c|c|c|c|}
\hline \multirow[b]{2}{*}{ Reach } & \multicolumn{2}{|c|}{ Sample size } & \multirow[b]{2}{*}{$x^{2}$} & \multirow[b]{2}{*}{$P>X^{2}$} \\
\hline & $\begin{array}{c}\text { Group } \\
\text { A }\end{array}$ & $\begin{array}{c}\text { Group } \\
\text { B }\end{array}$ & & \\
\hline Release to tailrace & 147 & 163 & 3.89 & 0.0485 \\
\hline Tailrace to Aufderheide Bridge & 94 & 92 & 0.53 & 0.4660 \\
\hline Aufderheide Bridge to McKenzie River & 83 & 77 & 12.82 & 0.0003 \\
\hline McKenzie River to Leaburg Dam & 47 & 39 & 4.28 & 0.0386 \\
\hline Leaburg Dam to Marshal Island & 40 & 18 & 12.02 & 0.0005 \\
\hline Marshall Island to Hops Farm & 30 & 11 & 0.74 & 0.3883 \\
\hline Release to Hops Farm & 41 & 18 & 1.05 & 0.3063 \\
\hline
\end{tabular}


Table C5. Results of Wilcoxon tests comparing travel time distributions of rearing groups $A$ and $B$ fish released into the tailrace of Cougar Dam, Oregon, December 18-22, 2012.

[ $\chi^{2}$ is Chi Square, $P$ is probability, $>$ is greater than, the numerator degrees of freedom was 1 in each comparison]

\begin{tabular}{lccccc}
\hline & \multicolumn{3}{c}{ Sample size } & & \\
\cline { 2 - 4 } \multicolumn{1}{c}{ Reach } & Group & Group & & \\
& A & B & $\mathbf{X 2}^{2}$ & P > X2 \\
\hline Release to Aufderheide Bridge & 70 & 69 & 6.91 & 0.0086 \\
Aufderheide Bridge to McKenzie River & 44 & 47 & 0.78 & 0.3758 \\
McKenzie River to Leaburg Dam & 29 & 31 & 4.17 & 0.0411 \\
Leaburg Dam to Marshal Island & 23 & 20 & 5.62 & 0.0178 \\
Marshall Island to Hops Farm & 12 & 10 & 0.00 & 0.9478 \\
& & & & \\
Release to Hops Farm & 18 & 13 & 0.10 & 0.7509 \\
\hline
\end{tabular}

Table C6. Results of Wilcoxon tests comparing travel time distributions of rearing groups A and B fish released into Cougar Reservoir, Oregon, December 18-22, 2012.

[ $\chi^{2}$ is Chi Square, $P$ is probability, $>$ is greater than, the numerator degrees of freedom was 1 in each comparison]

\begin{tabular}{lccccc}
\hline & \multicolumn{3}{c}{ Sample size } & & \\
\cline { 2 - 4 } \multicolumn{1}{c}{ Reach } & Group & Group & & \\
& A & B & & $\mathbf{X 2}$ & P > X2 \\
\hline Release to forebay & 48 & 43 & 0.00 & 0.9684 \\
Release to tailrace & 33 & 37 & 0.12 & 0.7281 \\
Tailrace to Aufderheide Bridge & 25 & 23 & 1.96 & 0.1618 \\
Aufderheide Bridge to McKenzie River & 17 & 14 & 0.57 & 0.4497 \\
McKenzie River to Leaburg Dam & 7 & 8 & 0.48 & 0.4891 \\
Leaburg Dam to Marshal Island & 6 & 6 & 1.25 & 0.2639 \\
Marshall Island to Hops Farm & 4 & 5 & 0.06 & 0.8097 \\
& & & & \\
Release to Hops Farm & 8 & 5 & 2.12 & 0.1457 \\
\hline
\end{tabular}

\section{Survival}

There was evidence to support an effect of rearing group on survival during each study, but the estimated differences were small. The potential for rearing group effects on survival was evaluated based on support of one model without a rearing group effect relative to several models with different hypothetical rearing group effects. The support of the models by the data was gauged using informationtheoretic methods (Burnham and Anderson, 2002). Data from the November study showed considerably less support for the model without a rearing group effect (model 1) compared to models with an effect, and there was considerable model-selection uncertainty, suggesting model-averaged results should be examined (table C7). The range of the differences between model-averaged reach-specific single-release estimates of survival of the two rearing groups was $0.0003-0.0669$, indicating the effect was small. The reach-specific relative survival estimates from the two rearing groups differed by a maximum of 0.0109 , which was well within the error of the estimates. 
Data from the December study supported rearing group effects on survival more than the data from the November study, but the effects in most reaches were small. The model without an effect of rearing group (model 1) was much less supported than the best model in the suite (model 4), as indicated by the delta AICc of 8.097 (table C7). Model-averaged estimates of the survivals of the two rearing groups were examined because of the model-selection uncertainty present, as indicated by the similarity in the AICc values of two of the models. The range of differences between the modelaveraged reach-specific single-release estimates of survival of the two rearing groups was 0.0030 0.2843 , indicating some differences were large. The largest differences were in the last two reaches, for which the estimates were imprecise. The range of differences in reach-specific single-release survival between the rearing groups for the three reaches between Cougar Dam and Leaburg Dam was 0.00300.0901 .

Table C7. Comparisons of models with and without effects of rearing group (rear) on estimates of survival of radiotagged juvenile Chinook salmon released near Cougar Dam, Oregon, November and December 2012.

[In addition to the factors listed, all models include factors of tagger, treatment group, and reach plus their 2-way interactions on survival (phi) and the factor of reach on detection probability (p). '+' indicates an additive effect, "“*” indicates a multiplicative effect, AICc is the Akaike Information Criterion adjusted for sample size, No. parm is number of parameters in the model. The estimated overdispersion parameter (c-hat) was near 1.0 for the November and December studies, so no adjustments were applied. The models are based on the log link function and are ordered by AICc value]

\begin{tabular}{|c|c|c|c|c|c|c|c|}
\hline $\begin{array}{l}\text { Model } \\
\text { number }\end{array}$ & Model description & $\mathrm{AICC}$ & $\begin{array}{l}\text { Delta } \\
\text { AlCc }\end{array}$ & $\begin{array}{l}\text { AICc } \\
\text { weights }\end{array}$ & $\begin{array}{c}\text { Model } \\
\text { likelihood }\end{array}$ & $\begin{array}{l}\text { No. } \\
\text { parm }\end{array}$ & Deviance \\
\hline \multicolumn{8}{|c|}{ 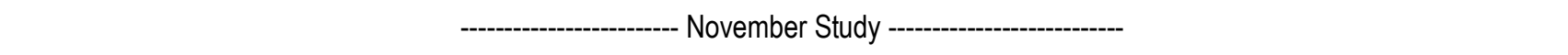 } \\
\hline 2 & Phi (rear+reach) & 2603.619 & 0.000 & 0.659 & 1.000 & 21 & 2561.007 \\
\hline 4 & Phi(rear*reach, rear*trt) & 2606.706 & 3.086 & 0.141 & 0.214 & 26 & 2553.771 \\
\hline 3 & Phi(rear*reach) & 2606.969 & 3.350 & 0.124 & 0.187 & 25 & 2556.105 \\
\hline \multirow[t]{2}{*}{1} & Phi(no rear effect) & 2607.940 & 4.321 & 0.076 & 0.115 & 20 & 2567.384 \\
\hline & & ------------- & er Study & 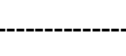 & & & \\
\hline 4 & Phi(rear*reach, rear*trt) & 2575.507 & 0.000 & 0.499 & 1.000 & 26 & 2522.460 \\
\hline 3 & Phi(rear*reach) & 2575.624 & 0.118 & 0.470 & 0.943 & 25 & 2524.656 \\
\hline 2 & Phi (rear+reach) & 2581.705 & 6.198 & 0.022 & 0.045 & 21 & 2539.019 \\
\hline 1 & Phi(no rear effect) & 2583.603 & 8.097 & 0.009 & 0.017 & 20 & 2542.980 \\
\hline
\end{tabular}


The data from each release date of the December study were examined because of the support for differences between the rearing groups. Estimates of single-release reach-specific survivals of the control and treatment groups released on each of the five dates were examined. The results indicated the survival of fish released on the first three dates was lower in rearing group B, but the survival of fish released on the last two dates were similar between groups; the trend was primarily evident in the treatment group and persisted through each reach. Data from the Aufderheide Bridge-to-McKenzie River reach are shown as an example in figure $\mathrm{C} 1$. However, the estimated reach-specific relative survivals with and without rearing group B were similar (fig. C2). This was likely due to the potential rearing-group effect being expressed in both treatment and control groups and nearly cancelling out in the estimates of relative survival. Based on these results the inferences about DPE, route-specific dam passage probabilities, and $\mathrm{RO}$ passage survival probabilities were based on data from both rearing groups pooled.

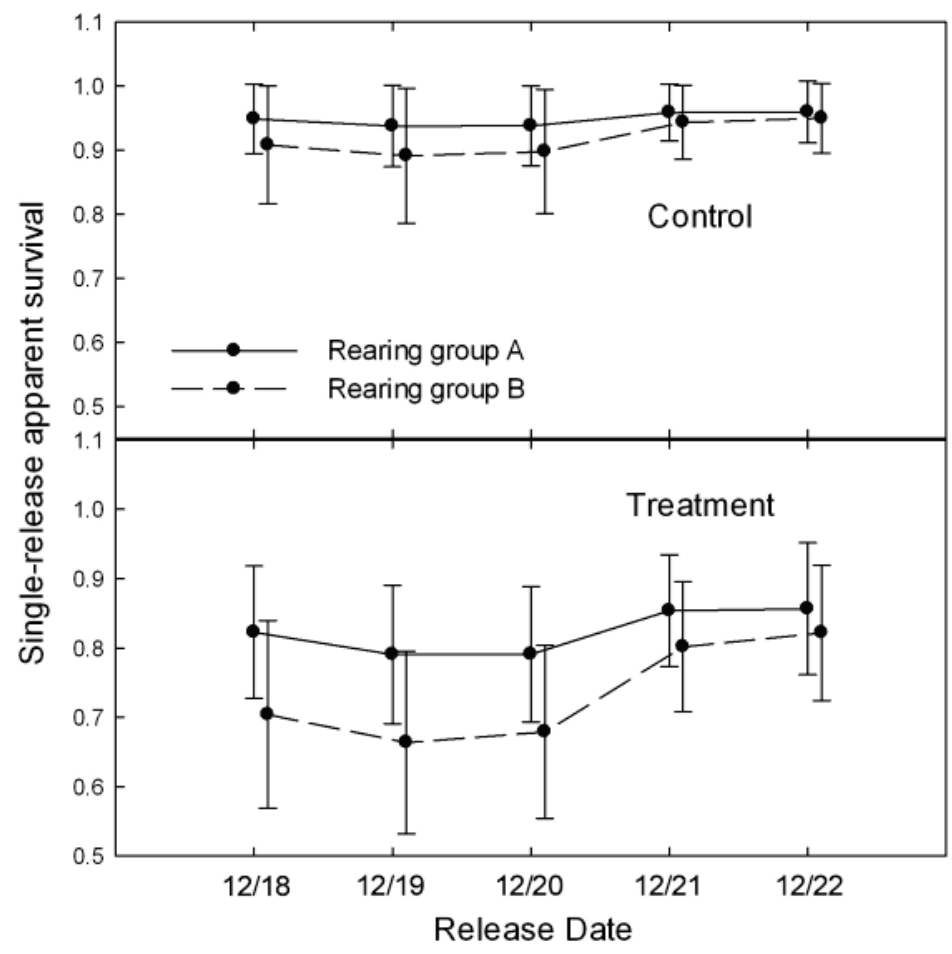

Figure C1. Estimates and 95-percent confidence intervals of unadjusted single-release survival of radio-tagged juvenile Chinook salmon from two rearing groups released near Cougar Dam, Oregon, December 2012. The results are from control and treatment groups passing through the Aufderheide Bridge-to-McKenzie River reach. 


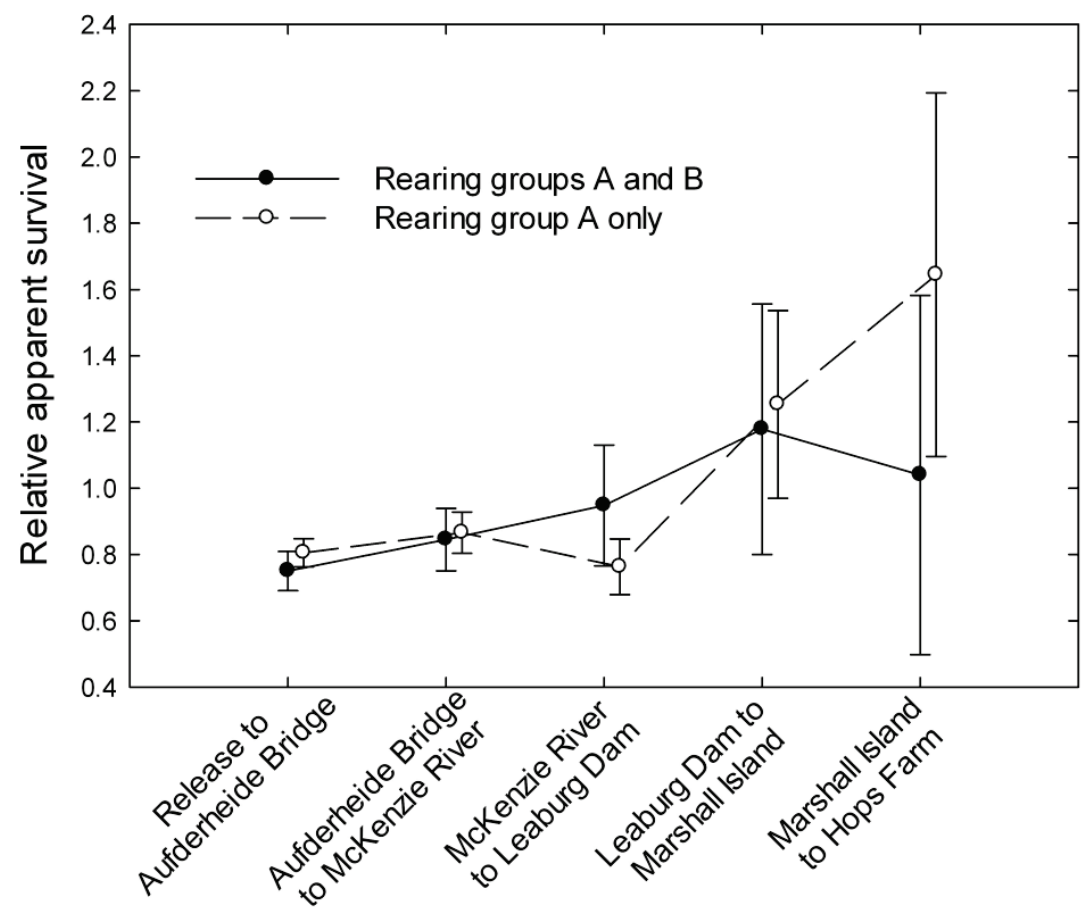

Figure C2. Estimates and 95-percent confidence intervals of unadjusted reach-specific relative survival of radiotagged juvenile Chinook salmon released near Cougar Dam, Oregon, December 2012. 


\section{Appendix D. Summaries of the Environmental and Operating Conditions at Cougar Dam, Oregon, November and December 2012 Studies}

Table D1. Summary statistics of dam operations and environmental conditions at Cougar Reservoir, Oregon, November 7 through December 23, 2012.

[This period represents the passage dates of fish released in the reservoir during the November study period. SD, standard deviation; $\mathrm{ft}^{3} / \mathrm{s}$, cubic feet per second]

\begin{tabular}{llrrrr}
\hline & Time period & Mean & Median & Range & SD \\
\hline Powerhouse $\left(\mathrm{ft}^{3} / \mathrm{s}\right)$ & Overall & 710.7 & $1,050.0$ & $0.0-1,300.0$ & 483.8 \\
& Day & 848.0 & $1,070.0$ & $0.0-1,300.0$ & 430.1 \\
& Night & 627.2 & $1,000.0$ & $0.0-1,190.0$ & 495.8 \\
Regulating outlet $\left(\mathrm{ft}^{3} / \mathrm{s}\right)$ & Overall & $1,602.9$ & $1,865.0$ & $0.0-6,780.0$ & 758.7 \\
& Day & $1,477.9$ & $1,705.0$ & $0.0-6,780.0$ & 915.4 \\
& Night & $1,679.1$ & $1,870.0$ & $0.0-3,860.0$ & 633.7 \\
Reservoir elevation (feet, NGVD29) & Overall & $1,550.8$ & $1,556.8$ & $1,504.0-1,595.4$ & 24.7 \\
& Day & $1,551.1$ & $1,558.1$ & $1,504.0-1,594.6$ & 24.9 \\
& Night & $1,550.6$ & $1,556.2$ & $1,504.0-1,595.4$ & 24.6 \\
Temperature (degrees Celsius) & Overall & 6.8 & 6.8 & $5.0-8.1$ & 0.6 \\
& Day & 6.9 & 6.8 & $5.0-8.1$ & 0.6 \\
& Night & 6.8 & 6.7 & $5.1-8.0$ & 0.6 \\
\hline
\end{tabular}

Table D2. Summary statistics of dam operations and environmental conditions at Cougar Reservoir, Oregon, December 18, 2012, through February 22, 2013.

[This period represents the passage dates of fish released in the reservoir during the December study period. SD, standard deviation; $\mathrm{ft}^{3} / \mathrm{s}$, cubic feet per second]

\begin{tabular}{llcrrr}
\hline & Time period & Mean & Median & Range & SD \\
\hline Powerhouse $\left(\mathrm{ft}^{3} / \mathrm{s}\right)$ & Overall & 243.3 & 330.0 & $0.0-510.0$ & 213.9 \\
& Day & 258.2 & 330.0 & $0.0-510.0$ & 213.6 \\
& Night & 232.3 & 330.0 & $0.0-510.0$ & 213.6 \\
Regulating outlet $\left(\mathrm{ft}^{3} / \mathrm{s}\right)$ & Overall & 331.9 & 0.0 & $0.0-2,370.0$ & 532.3 \\
& Day & 303.6 & 0.0 & $0.0-2,290.0$ & 516.8 \\
& Night & 352.7 & 0.0 & $0.0-2,370.0$ & 542.9 \\
Reservoir elevation (feet, NGVD29) & Overall & $1,528.9$ & $1,521.1$ & $1,500.7-1,569.3$ & 24.8 \\
& Day & $1,531.0$ & $1,524.0$ & $1,500.7-1,569.2$ & 25.3 \\
Temperature (degrees Celsius) & Night & $1,527.4$ & $1,519.9$ & $1,500.8-1,569.3$ & 24.3 \\
& Overall & 4.0 & 4.1 & $3.1-5.3$ & 0.5 \\
& Day & 4.0 & 4.1 & $3.1-5.2$ & 0.5 \\
& Night & 4.0 & 4.1 & $3.3-5.3$ & 0.5 \\
\hline
\end{tabular}


Table D3. Summary statistics of dam operations and environmental conditions at Cougar Reservoir, Oregon, November 6 through November 10, 2012.

[This period represents the release dates of fish released at the temperature control tower (treatment group) and in the tailrace (control group) during the November study period.SD, standard deviation; $\mathrm{ft}^{3} / \mathrm{s}$, cubic feet per second]

\begin{tabular}{llrrrr}
\hline & Time period & Mean & Median & \multicolumn{1}{c}{ Range } & SD \\
\hline Powerhouse $\left(\mathrm{ft}^{3} / \mathrm{s}\right)$ & Overall & 543.3 & 130.0 & $130.0-1,000.0$ & 436.3 \\
& Day & $1,000.0$ & $1,000.0$ & $1,000.0-1,000.0$ & 0.0 \\
& Night & 228.0 & 130.0 & $130.0-1,000.0$ & 277.0 \\
Regulating outlet $\left(\mathrm{ft}^{3} / \mathrm{s}\right)$ & Overall & $1,023.6$ & $1,395.0$ & $540.0-1,580.0$ & 431.7 \\
& Day & 574.7 & 570.0 & $540.0-600.0$ & 18.4 \\
& Night & $1,333.4$ & $1,420.0$ & $550.0-1,580.0$ & 279.7 \\
Reservoir elevation (feet, NGVD29) & Overall & $1,588.6$ & $1,588.6$ & $1,581.6-1,595.4$ & 4.0 \\
& Day & $1,588.7$ & $1,588.6$ & $1,582.4-1,594.6$ & 4.0 \\
& Night & $1,588.5$ & $1,588.0$ & $1,581.6-1,595.4$ & 4.1 \\
Temperature (degrees Celsius) & Overall & 6.7 & 6.5 & $5.8-8.0$ & 0.6 \\
& Day & 6.9 & 6.7 & $6.2-7.9$ & 0.6 \\
& Night & 6.6 & 6.4 & $5.8-8.0$ & 0.5 \\
\hline
\end{tabular}

Table D4. Summary statistics of dam operations and environmental conditions at Cougar Reservoir, Oregon, December 18 through December 22, 2012.

[This period represents the release dates of fish released at the temperature control tower (treatment group) and in the tailrace (control group) during the December study period. SD, standard deviation; $\mathrm{ft}^{3} / \mathrm{s}$, cubic feet per second]

\begin{tabular}{llrrrr}
\hline & Time period & Mean & Median & Range & SD \\
\hline Powerhouse $\left(\mathrm{ft}^{3} / \mathrm{s}\right)$ & Overall & 0.0 & 0.0 & $0.0-0.0$ & 0.0 \\
& Day & 0.0 & 0.0 & $0.0-0.0$ & 0.0 \\
& Night & 0.0 & 0.0 & $0.0-0.0$ & 0.0 \\
Regulating outlet $\left(\mathrm{ft}^{3} / \mathrm{s}\right)$ & Overall & $1,820.8$ & $2,000.0$ & $1,160.0-2,370.0$ & 350.1 \\
& Day & $1,855.1$ & $2,050.0$ & $1,290.0-2,290.0$ & 333.7 \\
& Night & $1,800.1$ & $1,980.0$ & $1,160.0-2,370.0$ & 360.2 \\
Reservoir elevation (feet, NGVD29) & Overall & $1,506.9$ & $1,505.3$ & $1,504.0-1,513.0$ & 3.2 \\
& Day & $1,506.8$ & $1,505.2$ & $1,504.0-1,512.0$ & 3.1 \\
& Night & $1,506.9$ & $1,506.1$ & $1,504.0-1,513.0$ & 3.2 \\
Temperature (degrees Celsius) & Overall & 5.1 & 5.2 & $5.0-5.3$ & $<0.1$ \\
& Day & 5.1 & 5.1 & $5.0-5.2$ & $<0.1$ \\
& Night & 5.2 & 5.2 & $5.1-5.3$ & $<0.1$ \\
\hline
\end{tabular}




\section{Appendix E. Estimating the Adequacy of Transmitter Life}

\section{Introduction}

A transmitter life study was conducted to test Assumption 7, which states that the fish status (live or dead) is correctly assessed. In the case of radio telemetry, when a transmitter fails, the mark is essentially lost. Significant premature failure of transmitters can negatively bias survival estimates, because survival models will interpret transmitter failure as mortality. However, if the rate of transmitter failure is known, survival estimates can be adjusted to correct for transmitter failure (Cowen and Schwartz, 2005; Townsend and others, 2006). Therefore, it is important to conduct a transmitter life study as a measure of insurance. If a transmitter life study is not conducted, then little recourse is available for accurately adjusting survival estimates after conducting a study and finding that transmitters failed prematurely. Premature transmitter failure may occur through a number of mechanisms including batch-specific manufacturing defects or fish travel times longer than expected. Thus, it is important to conduct a transmitter life study using a random subsample of transmitters that will be implanted in fish and test their performance under ambient field conditions during the study period. The methods of Townsend and others (2006) were used to achieve the following goals: (1) to estimate the probability that a transmitter was alive at any point in time after it was turned on, (2) to estimate the probability of transmitters being in the study area at any given point in time after release, and (3) to estimate the average probability of a transmitter being alive when passing telemetry arrays used for survival analysis. Given this information, it can be determined if the transmitter failure rate is high enough to warrant correction of survival estimates.

\section{Methods}

A transmitter life study was conducted with transmitters delivered for use in each of the November and December 2012 study periods. Prior to conducting the transmitter life study, we randomly selected 51 and 50 model NTQ-2 transmitters from the transmitters to be used for the survival study in November and December, respectively. The transmitters were held in a large circular fiberglass tank at the Columbia River Research Laboratory and supplied with a constant flow of ambient well water. A proportional amount of transmitters from each transmitter shipment were turned on, the date and time was recorded, and the transmitters were placed inside 7.6 L galvanized steel buckets to prevent the radio signal from transmitting beyond the confines of the tank. Due to the multiple shipment dates, transmitters were turned on in two batches for the November study and in one batch for the December study. Transmitters were monitored with a narrow-band radio-telemetry receiver until all transmitters ceased operation.

Next, we estimated the probability of a transmitter being alive at any given point in time. The lifetime of each transmitter was calculated as the elapsed time between the time a transmitter was turned on and the time that the last detection was recorded by the telemetry receiver. Any transmitter that ceased operation in less than 1 day was excluded from the analysis because we normally discover transmitters that malfunction within the 24-h recovery period of tagged fish. We then fit a survival distribution function to the transmitter life data to estimate the probability of a transmitter operating for a given amount of time. Although many forms of survival distribution functions can be fit to this data, we chose to use the Kaplan-Meier distribution because this distribution fits the transmitter life data well. The Kaplan-Meier survival distribution function takes the form

$$
\mathrm{S}(\mathrm{t})=\operatorname{Pr}\{T>\mathrm{t}\}
$$


where $S(t)$ is the probability of a transmitter surviving to time $t$. We used maximum likelihood methods to fit the Kaplan-Meier survival distribution function to the empirical survival distribution function. The empirical survival distribution function is simply the proportion of transmitters surviving to time $t$.

The probability that a transmitter is alive when it arrives at a detection site is dependent on the travel time of the transmitter to the detection site. For the paired-release survival model, the travel times of interest are from time of release of both treatment and control groups to the time of first detection at the most downstream arrays used for survival analysis, which was the Hops Farm site. In addition to fish travel time, the travel time of the transmitter must include all elapsed time that the transmitter was operating prior to fish release. Therefore, we recorded dates and times of all instances where transmitters were turned on or off, calculated the total elapsed time, and added this to the travel time of fish to each detection array. We then plotted the empirical cumulative travel time distribution, which is simply the proportion of fish arriving at a given detection array at time $t$, against the survival distribution function to understand whether most fish passed the detection arrays prior to transmitter failure.

To quantify the rate of transmitter failure we calculated the average probability that the transmitter was operational for the $i$ th release group to the $j$ th detection array (Townsend and others, 2006):

$$
\hat{P}\left(L_{i j}\right)=\frac{1}{k_{i j}} \sum_{x=1}^{k_{i j}} \hat{S}\left(t_{i j x}\right)
$$

Where $\hat{P}\left(L_{i j}\right)=$ average probability that a transmitter is alive at the jth detection array $(1=$ first detection at the last downstream array) from the ith release group ( $1=$ treatment released near the Cougar Dam temperature control tower, 2 = control released downstream from Cougar Dam just downstream of the confluence of the RO and the powerhouse tailraces).

$$
\hat{S}\left(h_{i j x}\right)=\text { the estimated probability that a transmitter is alive at time } \mathrm{t}_{\mathrm{ijx}} \text { for the } \mathrm{xth} \text { fish arriving at }
$$
the jth detection array for the ith release group. $\hat{S}\left(h_{i j x}\right)$ is calculated simply by plugging into the survival distribution function the travel time of each transmitter to each detection array.

$$
\mathrm{k}_{\mathrm{ij}}=\text { the total number of fish detected at the } \mathrm{jth} \text { detection array for the ith release group. }
$$

\section{Results}

Nearly all of the transmitters tested exceeded the expected minimum battery life of 31 days as specified by the manufacturer. The median operational life time was 56.4 days $(N=50$; range 45.1-73.2 days) for the November transmitters and 60.5 days ( $N=51$; range 28.4-80.2 days) for the December transmitters. Once transmitters began to fail, the remaining transmitters died soon thereafter as indicated by the survival distribution function (fig. E1). Ninety percent of all transmitters were live at 51.8 days and 55.0 days for the November and December studies, respectively. We used the maximum transmitter life from the November transmitters as one criterion to remove false positive records from the data. 
The comparison of cumulative travel times from release to the detection arrays and the survival distribution function indicated high probabilities of the transmitters being operational when the fish reached the arrays. During both studies, the lowest mean probability of the transmitters being functional for juvenile Chinook salmon was 0.9993 for travel time from the treatment release site to the most downstream array at the Hops Farm site (table E1). The probability of transmitters being functional from the control release site to the Hops Farm site was 1.0000 in both study periods. The high probability of a transmitter being operational in all reaches indicated a negligible probability of lost marks in the two studies, so no adjustments to the results were conducted.
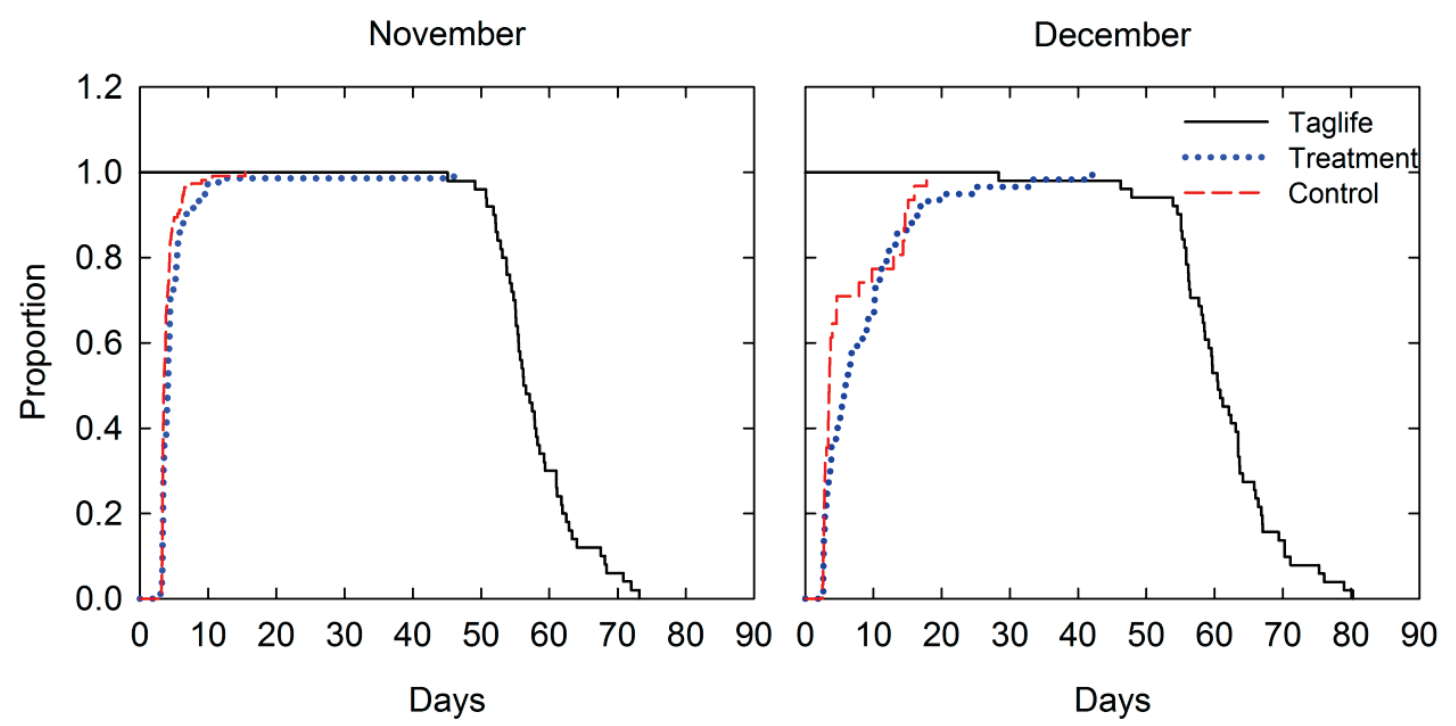

Figure E1. Cumulative travel time distributions of radio-tagged fish and the survival distribution function of radio transmitter life based on the studies at Cougar Dam, Oregon, November and December 2012. Cumulative travel times of juvenile Chinook salmon in treatment and control groups from transmitter activation to detection at the Hops Farm site are plotted with the survival distribution function for model NTQ-2 transmitters (Taglife).

Table E1. Estimated probabilities of transmitters being operational [ ${ }^{\hat{P}}\left(L_{i j}\right)$ ] when passing telemetry arrays used in the survival studies of fish released near Cougar Dam, Oregon, November and December 2012.

[SD, standard deviation]

\begin{tabular}{cccc}
\hline Study period & Reach & Mean & \multicolumn{1}{c}{ SD } \\
\hline November & Treatment release to Hops Farm & 0.9997 & 0.0024 \\
& Control release to Hops Farm & 1.0000 & 0 \\
December & Treatment release to Hops Farm & 0.9993 & 0.0036 \\
& Control release to Hops Farm & 1.0000 & 0 \\
\hline
\end{tabular}




\section{Appendix F. Comparisons of Models Considered for Estimating Detection, Passage, and Survival Probabilities of Juvenile Chinook Salmon Released Near Cougar Dam, Oregon, November and December 2012}

Table F1. Comparisons of models considered for estimation of detection, passage, and survival probabilities of juvenile Chinook salmon released near Cougar Dam, Oregon, November 2012.

[Model 13 was used for all estimation. AIC is the Akaike Information Criterion, No. parm is the number of parameters in the model, phi indicates survival probability, $p$ indicates detection probability, Pr indicates passage probability, “*” indicates a multiplicative effect, Trt indicates experimental group (control or treatment), con indicates control group, trt indicates treatment group, CJS indicates use of Cormack-Jolly-Seber methods to estimate route-specific detection probabilities in lieu of the auxiliary likelihood method. Models are sorted from the most general to least general]

\begin{tabular}{|c|c|c|c|c|c|c|}
\hline $\begin{array}{l}\text { Model } \\
\text { number }\end{array}$ & Model description & AIC & Delta AIC & $\begin{array}{l}\text { No. } \\
\text { parm }\end{array}$ & $\begin{array}{l}\text { Model } \\
\text { weight }\end{array}$ & Deviance \\
\hline \multicolumn{7}{|c|}{ 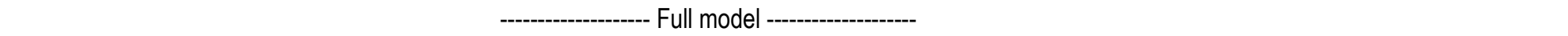 } \\
\hline 1 & Full model: phi $(\operatorname{Trt} *$ diel + reach $), p(\operatorname{Trt} *$ diel + reach $), \operatorname{Pr}(\operatorname{Trt} *$ diel $)$ & 906.10 & 145.14 & 81 & 0.00 & 744.10 \\
\hline \multicolumn{7}{|c|}{ 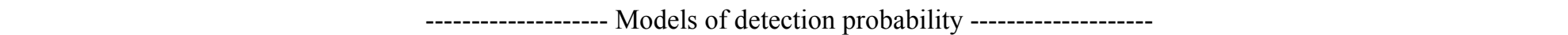 } \\
\hline 2 & model 1 with CJS for RO night & 875.15 & 114.19 & 72 & 0.00 & 731.15 \\
\hline 3 & model 1 with CJS for RO day & 878.39 & 117.44 & 72 & 0.00 & 734.39 \\
\hline 4 & model 1 with CJS for RO day = night & 853.36 & 92.40 & 70 & 0.00 & 713.36 \\
\hline 5 & model 4 with CJS at Leaburg Dam spillway night (trt) & 846.78 & 85.83 & 69 & 0.00 & 708.78 \\
\hline 6 & model 4 with CJS for Leaburg Dam spillway day (trt) & 851.36 & 90.40 & 69 & 0.00 & 713.36 \\
\hline 7 & model 4 with CJS at Leaburg Dam spillway day = night (trt) & 831.69 & 70.73 & 67 & 0.00 & 697.69 \\
\hline 8 & model 7 with CJS for Leaburg Dam spillway night (con) & 809.74 & 48.79 & 66 & 0.00 & 677.74 \\
\hline 9 & model 7 with CJS for Leaburg Dam spillway day (con) & 802.89 & 41.93 & 66 & 0.00 & 670.89 \\
\hline 10 & model 7 with CJS for Leaburg Dam spillway day = night $($ con) & 779.45 & 18.49 & 64 & 0.00 & 651.45 \\
\hline 11 & model 10 with day $=$ night for remaining Ps $(\operatorname{trt} \neq$ con $)$ & 767.12 & 6.16 & 56 & 0.02 & 655.12 \\
\hline \multicolumn{6}{|c|}{ 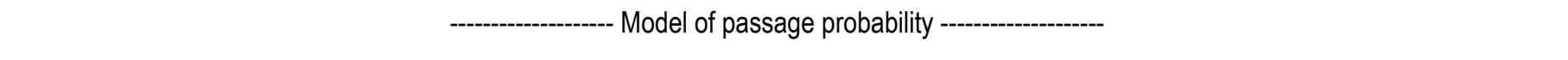 } & \multirow{2}{*}{655.13} \\
\hline 12 & model 11 with day=night for $\operatorname{Pr}_{\text {spill }}$ and $\operatorname{Pr}_{\text {byp }}$ at Leaburg Dam & 761.13 & 0.17 & 53 & 0.47 & \\
\hline & - & & & & & \\
\hline 13 & Phi (treatment $*$ reach), p (model11), $\operatorname{Pr}$ (model 12) & 760.96 & 0.00 & 43 & 0.51 & 674.96 \\
\hline
\end{tabular}


Table F2. Comparisons of models considered for estimation of detection, passage, and survival probabilities of juvenile Chinook salmon released near Cougar Dam, Oregon, December 2012.

[Model 13 was used for all estimation. AIC is the Akaike Information Criterion, No. parm is the number of parameters in the model, phi indicates survival probability, p indicates detection probability, Pr indicates passage probability, “*” indicates a multiplicative effect, Trt indicates experimental group (control or treatment), con indicates control group, trt indicates treatment group, CJS indicates use of Cormack-Jolly-Seber methods to estimate route-specific detection probabilities in lieu of the auxiliary likelihood method. Models are sorted from the most general to least general]

\begin{tabular}{|c|c|c|c|c|c|c|}
\hline $\begin{array}{c}\text { Model } \\
\text { number }\end{array}$ & Model description & AIC & Delta AIC & $\begin{array}{c}\text { No. } \\
\text { parm }\end{array}$ & $\begin{array}{l}\text { Model } \\
\text { weight }\end{array}$ & Deviance \\
\hline & 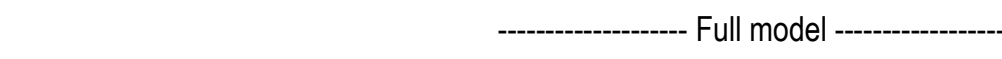 & & & & & \\
\hline \multirow[t]{2}{*}{1} & Full model: phi $(\operatorname{trt} *$ diel + reach $), p(\operatorname{trt} *$ diel + reach $), \operatorname{Pr}(\operatorname{Trt} *$ diel $)$ & 777.88 & 168.21 & 59 & 0.00 & 659.88 \\
\hline & ---------------- Models of detection proba & ---------- & ------ & & & \\
\hline 2 & model 1 with CJS for RO night & 731.36 & 121.70 & 53 & 0.00 & 625.36 \\
\hline 3 & model 1 with CJS for RO day & 729.73 & 120.07 & 53 & 0.00 & 623.73 \\
\hline 4 & model 1 with CJS for RO day = night & 717.93 & 108.26 & 51 & 0.00 & 615.93 \\
\hline 5 & model 4 with CJS at Leaburg Dam spillway night (trt) & 699.00 & 89.34 & 50 & 0.00 & 599.00 \\
\hline 6 & model 4 with CJS for Leaburg Dam spillway day (trt) & 682.60 & 72.94 & 50 & 0.00 & 582.60 \\
\hline 7 & model 4 with CJS at Leaburg Dam spillway day $=$ night (trt) & 663.12 & 53.45 & 48 & 0.00 & 567.12 \\
\hline 8 & model 7 with CJS for Leaburg Dam spillway night (con) & 632.79 & 23.12 & 47 & 0.00 & 538.79 \\
\hline 9 & model 7 with CJS for Leaburg Dam spillway day (con) & 650.31 & 40.64 & 47 & 0.00 & 556.31 \\
\hline 10 & model 7 with CJS for Leaburg Dam spillway day = night $($ con $)$ & 618.13 & 8.46 & 45 & 0.01 & 528.13 \\
\hline \multirow[t]{2}{*}{11} & model 10 with day $=$ night for remaining Ps $(\operatorname{trt} \neq$ con $)$ & 615.42 & 5.75 & 39 & 0.03 & 537.42 \\
\hline & 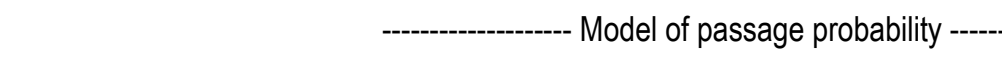 & & & & & \\
\hline 12 & model 11 with day=night for $\operatorname{Pr}_{\text {spill }}$ and $\operatorname{Pr}_{\text {byp }}$ at Leaburg Dam & 610.78 & 1.12 & 36 & 0.35 & 538.78 \\
\hline 13 & Phi (treatment $*$ reach), p (model model11), $\operatorname{Pr}($ model 12$)$ & 609.67 & 0.00 & 26 & 0.61 & 557.67 \\
\hline
\end{tabular}




\section{Appendix G. Single-Release Estimates of Reach-Specific Survival of Treatment and Control Groups Used to Estimate Relative Survival of Fish Passing Cougar Dam, Oregon, November and December 2012}

[Estimates for the Release to Leaburg Dam and Release to McKenzie River reaches are adjusted for detection of euthanized fish with live transmitters]

\begin{tabular}{|c|c|c|c|c|c|c|c|c|}
\hline \multirow[b]{4}{*}{ Reach } & \multicolumn{4}{|c|}{ Treatment } & \multicolumn{4}{|c|}{ Control } \\
\hline & \multirow[b]{3}{*}{ Estimate } & \multirow{3}{*}{$\begin{array}{c}\text { Standard } \\
\text { error }\end{array}$} & \multicolumn{2}{|c|}{ 95-percent confidence } & \multirow[b]{3}{*}{ Estimate } & \multirow{3}{*}{$\begin{array}{c}\text { Standard } \\
\text { error }\end{array}$} & \multirow{2}{*}{\multicolumn{2}{|c|}{$\begin{array}{l}\text { 5-percent confidence } \\
\text { interval }\end{array}$}} \\
\hline & & & & & & & & \\
\hline & & & lower & upper & & & lower & upper \\
\hline & \multicolumn{8}{|c|}{ November Study } \\
\hline Release to Leaburg Dam & 0.4716 & 0.0469 & 0.3796 & 0.5636 & 0.9655 & 0.0262 & 0.9141 & 1.0168 \\
\hline Leaburg Dam to Marshall Island & 0.7708 & 0.0515 & 0.6699 & 0.8716 & 0.8195 & 0.0388 & 0.7435 & 0.8955 \\
\hline \multirow[t]{2}{*}{ Marshall Island to Hops Farm } & 0.5556 & 0.0499 & 0.4577 & 0.6535 & 0.7239 & 0.0420 & 0.6417 & 0.8062 \\
\hline & \multicolumn{5}{|c|}{-------- December Study -. } & & & \\
\hline Release to McKenzie River & 0.6373 & 0.0409 & 0.5570 & 0.7175 & 0.9556 & 0.0382 & 0.8807 & 1.0305 \\
\hline McKenzie River to Leaburg Dam & 0.8768 & 0.0550 & 0.7691 & 0.9846 & 0.9189 & 0.0698 & 0.7821 & 1.0556 \\
\hline Leaburg Dam to Marshall Island & 0.7699 & 0.0779 & 0.6172 & 0.9226 & 0.6630 & 0.0855 & 0.4955 & 0.8305 \\
\hline Marshall Island to Hops Farm & 0.3787 & 0.0544 & 0.2722 & 0.4853 & 0.3643 & 0.0816 & 0.2044 & 0.5242 \\
\hline
\end{tabular}


Publishing support provided by the U.S. Geological Survey Publishing Network, Tacoma Publishing Service Center

For additional information contact:

Director, Western Fisheries Research Center

U.S. Geological Survey

6505 NE 65th Street

Seattle, Washington 98115

http://wfrc.usgs.gov/ 


\section{है}

एా

$\stackrel{\mathbb{D}}{\stackrel{8}{3}}$

丞

产

学

$\frac{5}{4}$

ग

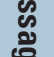

\%ั

言

$\stackrel{5}{E}$

కุ․․

훙

흘.

홍

으

产

言.

产

蛋

흠

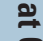

ํํㅇ

$\stackrel{2}{2}$

竞

옹

일

芩

!

旁 